CHAPTER TWO

\title{
A DESCRIPTION OF THE DIALECTS OF THE MZĒNAH AND BANIY WĀṢIL
}

\section{INTRODUCTION}

The largest tribe of the central, south and southeastern Sinai are the Mzēnah (or Muzaynah). The much smaller tribe of Baniy Wāṣil live near the town of at-Tür and towards the east of it and in the western part of the massif of the central south of Sinai, where they are neighbours of the Awlād Sa ${ }^{1} \mathrm{I}^{1}$ and the Garāršah, who live to their north. The dialects of Mzēnah (MzA) and Baniy Wāṣil (BWA) share some important characteristics, and are therefore treated in one chapter. Originally, however, the dialect of the Baniy Wāṣil must have been more like the dialect-type of group I, with which it still shares a number of features not found in Mzēniy. Some of these features actually occur parallel to features also heard in Mzēniy, while other characteristics are still uniquely (inside Sinai, that is) found in group I. Wāṣliy is therefore treated here together with Mzēniy, partly for contrastive purposes and partly because it must have developed towards Mzēniy.

On the location of Baniy Wāșil, as it appears on the maps in this study, the following must be taken into account: although their territory does not directly border on the territory of the Mzēnah, in practice the Awlād Sa $\overline{1} \mathrm{i} d$, whose territory is indicated to lie between that of the Baniy Wāṣil and that of the Mzēnah, actually live more inland, i.e. in and around Wādiy Șlāf in the central mountain massif,² where they are direct neighbours of the Ğbāliyyah. The coastal plain of the dīrah of the Awlād Sacīd is in fact empty land (the sandy coastal plain al-Gāc), and hence the Baniy Wāṣil are-more or less_-direct neighbours of the Mzēnah.

\footnotetext{
${ }^{1}$ Although the dīrah of Awlād Sa'ìd is indicated on the map as bordering the Gulf of Suez, members of this tribe actually do not live in this deserted coastal plain (known as $G \bar{a}^{c} a \check{s} \breve{S} a r m$ or simply $\left.a l G \bar{a}\right)$, but are found more up in the mountains to the east. In effect, the Mzēnah and Baniy Wāșil (who do inhabit the coastal area on the Gulf of Suez near aț-Ṭur) are direct neighbours.

${ }_{2}$ The coordinates are appr. 28.32.35 North and 33.43.55 East, see Google Earth.
} 
In the following chapter a decription of the characteristics of both dialects is given, unless explicitly stated otherwise.

\section{Phonology}

\subsection{Consonants}

1.1.1. Inventory of consonants

The inventory of consonantal phonemes of MzA and BWA is:

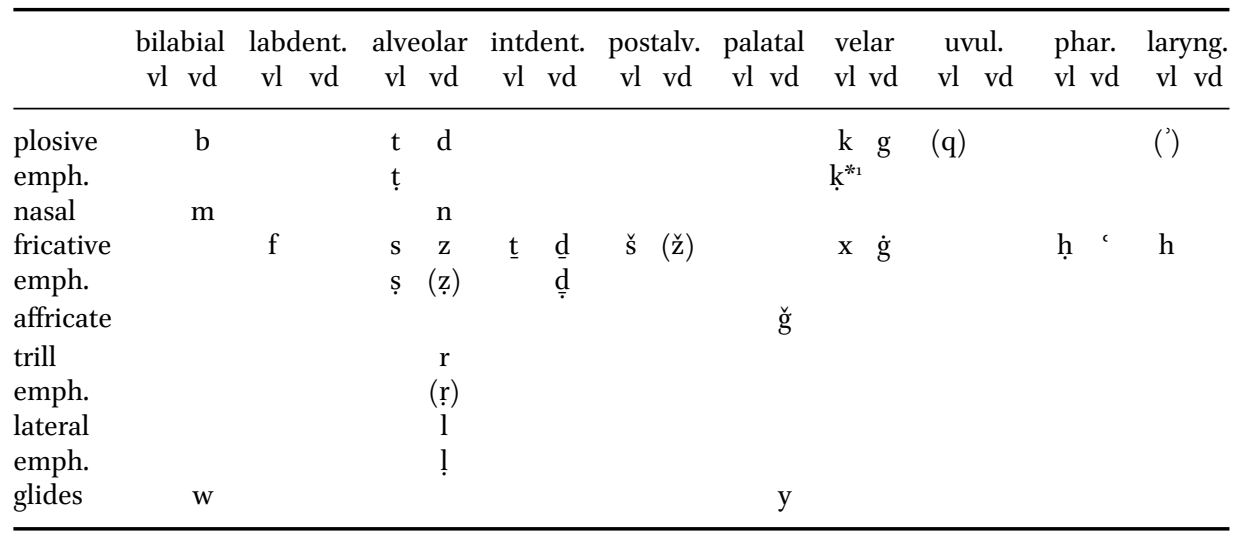

$\mathrm{vd}=$ voiced, $\mathrm{vl}=$ voiceless, emph. $=$ emphatic/velarized

The greatest difference with the inventory of group I is the presence of both $/ \mathrm{k} /$ and $/ \mathrm{k} /$, which is also a feature of group II in the north and of dialects of groups VII and VIII. A minimal pair xud bāluk-x in BWA) "pay attention (sg. masc.—sg. fem.)" isolates $/ \mathrm{k} /$ and $/ \mathrm{k} /$ as phonemes.

${ }^{*}$ See remarks in 1.1.3. below.

\subsubsection{Interdental fricatives $/ \underline{t} /, / d /$ and $/ \underline{d} /$}

The reflexes of * $\underline{t}$ and ${ }^{*} \underline{d}$ are interdentals $\underline{t}$ and $\underline{d}$ (I.P.A. $[\theta]$ and $[\gamma]$ respectively).

Examples for *ț are: naharit "we plough" (MzA), tāniy "second" (both), tyāb "clothes" (BWA), (')at tarhuw "their tracks" (BWA).

For *d: nāxid "we take" (both), migdāaf "oar" (MzA), mnadbaḥuh "we slaughter him" (MzA), idn "ear" (MzA), dikr "mention" (BWA), dimimih "ugly" (BWA), xud bāluk "pay attention, mind you" (BWA).

There are also exceptions: "refrigerator" and "ice; snow" are with $t$ in both dialects: tillāğah and talğ. 
In some loans from MSA (presumably via speakers of Cairene) the reflex for *t is $s$, e.g. hadīs "modern" (BWA) and also haras (!) ${ }^{3}$ "he ploughed" (BWA), masalan "for instance" (both) and for *d it is sometimes $z$, as in bizr "seed" (BWA) and kizāluk ${ }^{4}$ "as well".

Emphatic d (I.P.A. velarized [ð]) is the interdental reflex of *d and * $\underline{\underline{d}}$, e.g. (as reflex of *d in) raw $\underline{d}$ (pl. rị $\underline{d} \bar{a} n$ ) "small wadi between low moun-

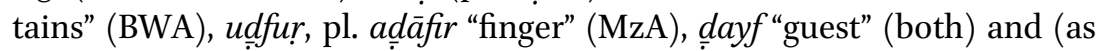

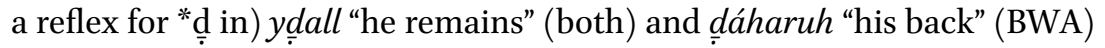
and álgada" "(the) inferior type of firewood" (BWA).

In a number of lexemes $z$ (usually loans from MSA or Egyptian Arabic) is the current reflex, like in mwazzafin "civil servants", zubbāt "officers" (both BWA), b-izzabt "precisely" (both), binzabbit "we do a proper job", nizām "system" (both MzA), etc.

In both dialects the sg. masc. demonstrative $(h \bar{a}-) \underline{d} a$ "this (sg. masc.)" is without velarization.

\subsubsection{Velar stops $/ k /$ and $/ g /$}

Like in the other dialects of Sinai, *k and * $\mathrm{q}$ have unaffricated reflexes $k$ and $g$.

Although in both dialects $k$ and $k$ are heard, only in MzA we find a true phonemic opposition in a minimal pair like ìduk "your (sg. masc.) hand"idik "your (sg. fem.) hand"; in BWA (sg. fem.) pronominal suffixes -ik and -kiy are used as parallel forms ${ }^{5}$ (i.e. $\bar{\imath} d i k$, as well as $\bar{\imath} d k i y$, the latter of which is the original BWA form and which is normally used). A true phonemic opposition between $/ \mathrm{k} /$ and $/ \mathrm{k} /{ }^{6}$ such as that existing in MzA, appears to be developing in BWA.

Similarly we find the (sg. masc.) pron. suffix C-ak (and its allomorph $\overline{\mathrm{v}}-k$ ) parallel to the (sg. masc.) pronominal suffix $-k$ in BWA.

In MzA "cigarette" is sigạrah (not like in many other dialects siğārah).

3 A sibilant $s$ for interdental $\underline{t}$ in the verb harat, yaharit "plough" is usually (i.e. in other dialects of Sinai) not one of the exceptions.

4 Compare MSA ka-dālik, of which morpheme boundaries were reinterpreted as kad̄al-ik, after which $l$-ik "to you (sg. fem.)" was adapted as $l$-uk (for sg. masc.).

${ }^{5}$ For the notion of 'parallel forms' as a characteristic of a transitional stage in dialect change due to dialect contact, see Trudgill 1983:chapter 5 and remarks in De Jong 2000:28, 596-597.

6 'True' in the sense that the two phonemes can be isolated in a minimal pair. 


\subsubsection{Post alveolar affricate /ğ/}

The allophone $\check{z}$ (I.P.A. [3]) for / $\check{g} /$ is particularly frequent in MzA. It was not recorded in BWA.

\subsubsection{Emphatic alveolar stop /ț/}

In all dialects of group I of the south, and also in group VI, a measure of glottalization in the realisation of / $t /$ may occur. Often the glottal release, which coincides with the release of the $t$, is not very clear. What is clear, is the lack of aspiration in the release of $t$, and the immediate onset of a following vowel.

\subsubsection{Glottal stop (hamzah)}

Like in many dialects of Sinai, the reflex for *' in the verb ask is 's sa al, yas 'al.

In * $r a$ 's "head", loss of 'is complemented by lengthening the preceding vowel > rās (pl. rūus).

\subsubsection{Secondary velarization}

What strikes the ear first of all when one hears MzA is the lack of velarization in positions where neighbouring group I dialects in Sinai appear to have it almost as a matter of natural fact. It is a feature of which one of my Mzēniy informants was quite aware; when asked to mention a few differences of his own dialect with that of the Tarābīn (who are their neighbours to the north), he mentioned kibbäyih "(drinking) glass", pl. kibäbiy, where a Turḅāniy would say kuḅbāayih and kuḅāḅiy. MzA rikbih (pl. rkab) "knee" is pronounced rukḅah (pl. rḳab) in TAN, and MzA siwwāg "driver" is sawwāg in TAN.

The imperfects of "eat" and "take" are not (or at best only minimally) velarized, whereas the imperatives are: (imperfects) yāxid and yākil, but velarization is heard in (imperative forms) $k u l$ and $x u \underline{d}$.

Compared to TAN, long $\bar{a}$ in MzA is also noticeably higher in positions not influenced bij velarization, e.g. șiyy äd "fisherman", riğǧäl "man", kiššä "flashlight", 'ițšän "thirsty" ( $\overline{\ddot{a}}$ is used here to indicate a phonetic value between I.P.A. [æ:] and [ع:]). In TAN the long $\bar{a}$ is considerably lower (nearer to I.P.A. [a:]): șiyyād, raǧğāl, kaššāf, 'aț̌̌̄an.

Another difference with TAN is MzA and BWA demonstrative hä $\underline{d} a$

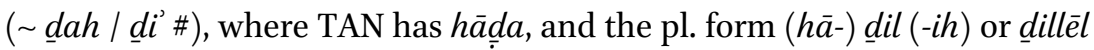
$(-i h)(\sim h \bar{a} \underline{d} \bar{o} l$ in BWA) where group I dialects have heavily velarized forms 


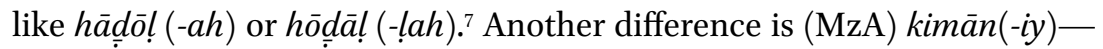
(TAN) kumịān "also".

\subsubsection{Liquids l and $\mathrm{r}$}

On the other hand, MzA and BWA, like many dialects in Sinai (including TAN), have strong velarization ${ }^{8}$ in $x \bar{a} f$ "he feared" (and also $x \bar{a} y i f$ "afraid" in MzA), $\dot{g} \bar{a} b$ "he was absent", rug்fạn "loaves (of bread)", (in the first syllable of ) xfạyyif "light", nār "fire", xyār "gherkins" and (i)nfār "persons" and himrāa "red (sg. fem.)”, 'iwrāa "one eyed (sg. fem.)”, bi '̣ān "camels” and rāās "head" (but no velarization in frāš "blanket").

Uvulars followed by $l$ or $r$ are especially prone to become velarized as an accompanying phonetic feature, ${ }^{9}$ e.g. ag்labiyyah "majority", šu $\dot{g} !$ "genitive exponent", naxa! "palm trees", xa!l "let! (imperative)", nuxrah (pl. nxar) "nose", baxarrif "I speak", nugrah (pl. ngar) "pit, pothole", bagra "I read (i.e. study)", garār "decision", grayyib "near", ga!̣ "heart", gālat "she said", glayyil "few, little" (g!̣a l "few (pl.)" and aga!l "less") and Rās Abuw Gallūm "name of a cape between Dahab and Nwēbi".

Generally, like in group I, the combination $\bar{a} r$ will be velarized, unless $i$ follows within morpheme boundaries (see also De Jong 2000:65-67). An exception is the pl. for kițir "many", which is kt $\underline{\ddot{a} r}$ in MzA and BWA (with a long $\bar{a}$ almost as high up as I.P.A. [ $\left.\varepsilon^{\prime}\right]$ ), but velarized $k \underline{t} \bar{a} r$ in TAN, whereas groups I and VI both have velarized $k b \bar{a} r$ as the pl. for kibir "old, big". There are many examples of velarized $\bar{a} r$, of which some are: mitmārah "(cylindrically shaped) grain silo", ${ }^{10}$ xyār "gherkins" (BWA), sinnārah "fishing hook", nār "fire", nahār "day (-light)". Also: sigārah "cigarrette", xuwwāạ "inferior type of camel, raised for its meat", byār "wells", Badārah "name of the tribe Badārah".

Notice, however, how following (either 'vanished' $i$ within morpheme boundaries blocks such velarization, e.g.: mizāri "lands for cultivation", midāris "schools", šāri "street" and 'ārif "knowing (sg. masc.)".

\footnotetext{
7 See De Jong 2000:170-172.

${ }^{8}$ Combinations of a velar $(g, x$ or $\dot{g})$ with $l, r$ or $b$ will often produce velarization, especiallly with $u, \bar{u}$ or $a, \bar{a}$ in their vicinity.

9 The articulation of uvulars involves some raising of the back of the tongue (towards the uvula). The process of velarization also involves a degree of raising of the back of the tongue.

${ }_{10}$ mițārah is also used for "pit for storing grain or belongings", see Bailey 2009:347 (glossary). The rocky mountains, more or less shaped like grain silos and located appr. at 28.51.46 North and 34.27.31 East, are also locally known as Ğabal Mațāmìr.
} 
Also sequences $r \bar{a}$ are generally not velarized when (vanished) $i$ precedes, or follows in the next syllable within morpheme boundaries, e.g. marākib "boats", grāyah (cf. MSA qiräah) "studying (lit. reading)", frāš "blanket" (cf. MSA firāš), Garāršah "name of tribe" (compare with MSA Qarārišah) and rākib "riding (sg. masc.)", but there is velarization in forms like rās "head", barrāàd "teapot" and harāạah "heat".

\subsubsection{Nasaln}

No remarks.

\subsubsection{Devoicing of final voiced stops, liquids and nasals in pause}

Devoicing of voiced stops, liquids and nasals in pause is regular in MzA and BWA.

One of my informants claimed that one feature of MzA is the type of glottalization of $\bar{a}$ in a final sequence $-\bar{a} C$ in pause, by which the final consonant is no longer produced (compare the situation described in remarks on TyA in 1.1.10. of chapter III). I have not been able to verify his claim.

\subsection{Vowels}

1.2.1. Inventory of vowel phonemes

The inventory for vowel phonemes contains three short vowels and five long vowels:

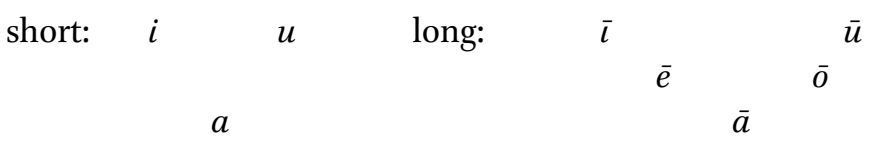

\subsubsection{Long vowels}

1.2.2.1. Allophones of long vowels $\overline{\mathrm{e}}$ and $\overline{\mathrm{l}}$

Unlike in group I dialects, phonetic overlapping of $/ \overline{\mathrm{e}} /$ and $/ \overline{\mathbf{l}} /$ is rare in group VI dialects.

The phonemic status of $/ \overline{\mathrm{e}} /$ and $/ \overline{\mathbf{l}} /$ can be established with a minimal pair like: šèn "bad"—š̌n "name of letter š", and /â/ may be isolated by pairing either of these with $(\min )$ šān "because of".

In MzA imperfect forms of the verb "dry" (root $y$ - $b$-s) monophthongization takes place, e.g. yēbas (< *yaybas) "he dries (intrans.)". 


\subsubsection{Allophones of long vowels $\overline{\mathrm{o}}$ and $\overline{\mathrm{u}}$}

In neutral environments, i.e. in the absence of velarization and without preceding back spirants, older diphthongs * ay and *aw have been monophthongized as $\bar{e}$ and $\bar{o}$. As long vowels, the phonemic status of $/ \overline{\mathrm{u}} /$ and $/ \overline{\mathrm{o}} /$ can be established through minimal pairs like:

$$
\begin{aligned}
& r u ̄ h \text { "go! (imperative sg. masc.)"—rōh "soul" } \\
& g \bar{u} l \text { "say! (imperative sg. masc.)"—gōl "speaking". }
\end{aligned}
$$

In positions influenced by velarization, $/ \overline{\mathrm{u}} /$ is realized relatively low, near I.P.A. [O:].

In verbs with $w \bar{a} w$ as $\mathrm{C}_{1}$ the diphthong aw has usually been monophthongized, as is illustrated in e.g. nōgaf "we stand" and also tōgid "you light" (both in MzA and BWA). In both dialects the imperative of $w^{-}-y$ "pay attention, take heed" has an initial diphthong: aw in rūskin "mind (pl. fem.) your heads!"."

\subsubsection{Allophones of long vowel $\bar{a}$}

Allophones of the long vowel / $\bar{a} /$ are ruled by the same principles as in group VII.

\subsubsection{Shortening of long vowels}

Like in group I dialects, shortening of unstressed long vowels is a characteristic of allegro style of speech in group VI dialects as well.

\subsubsection{Short vowels}

\subsubsection{Isolating phonemes $/ i /, / u /$ and $/ a /$}

Minimal pairs listed for groups VII and VIII also produce the phonemes /i/, /u/ and /a/ in MzA and BWA.

\subsubsection{Phonetic factors influencing the quality of $\mathrm{I}$}

In principle, distribution of short high vowels $i$ and $u$ is governed by the same rules as described for group I in De Jong 2000:70-74: a short high vowel tends to be $u$ (i.e. near I.P.A. [v]) in velarized and/or labial environment, otherwise $i$ (i.e. near I.P.A. [1]).

The pl. com. of ašdaf "left-handed" was recorded as šidf in BWA, but as šudf in MzA. Similarly, the pl. com. of a'arağ "lame, limping" has the high

${ }^{11}$ The imperative $a w^{\prime} a$ is often not inflected for number or gender, e.g. aw'a rūskuw! or aw'a rāsik! (instead of aw'uw and aw'iy respectively). Apocopated imperative forms of this verb have not been recorded, thus e.g. aw'a tans! "don't you forget!". 
vowel $i$ in 'irğ in BWA, but $u$ in 'urğ in MzA and that of a'ama "blind" is 'imy in BWA, but 'umy in MzA. Other pl. com. forms of the pattern $\mathrm{aC}_{1} \mathrm{C}_{2} \mathrm{aC}_{3}$, used for colours and physical defects, recorded in both dialects have a $\mathrm{C}_{1} \mathrm{uC}_{2} \mathrm{C}_{3}$ pattern (most have some degree of velarization), e.g. (sg. masc. ahamar) humr "red", (sg. masc. azrag) zurg "black", ${ }^{12}$ (sg. masc. axadar) ${ }^{13}$ xudr "green", (sg. masc. asfar) șufr "yellow" and (sg. masc. ahabal) hubl "dim-witted" (where labialization of the $b$ triggers the appearance of $u$ ), (sg. masc. agra ${ }^{\dagger}$ ) gur "bald", turm (sg. masc. atram) "gap-toothed".

Both dialects have $i$ in the imperfect of primae hamzah verbs: $y \bar{a} x i \underline{d}$ and $y \bar{a} k i l$ "he takes" and "he eats", but $u$ in the sg. masc. imperative: $k u l$ and xud "eat!" and "take!" (resp.) and clear velarization, caused by the 'van-

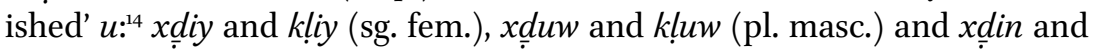
klin (pl. fem.).

Imperfect forms of mediae geminatae verbs recorded in group VI corroborate the rule formulated in De Jong 2000:72-73: $u$ appears near primary and (potentially) secondary emphatics, while $i$ appears in neutral environments. Examples are:

MzA: yhuttt "place", yrudd "answer", ydugg "inject (with a needle)",

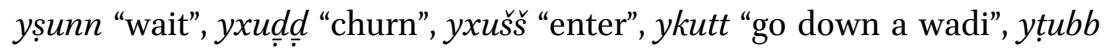
"go on a journey to", ylugg "hit", ${ }^{5}$ y "loosen", ywišs "swing a fishing net over one's head", ${ }^{16}$ ymidd "stretch", ytiff "spit", yliff "wrap", y'idd "count", yfitt "prepare fatītah".

\subsubsection{Morphological conditioning of the short high vowel}

So far we have seen that often a velarized or labial environment triggers the appearance of $u$. Morphology, however, will over-rule this phonetic feature, as far as distribution of short high vowels is concerned. For instance, measures 2, 3 and 4 will have $i$ in the imperfect forms, such as $\mathrm{yC}_{1} \mathrm{aC}_{2} \mathrm{C}_{2} \mathrm{iC}_{3}$ (measure 2), $\mathrm{yC}_{1} \overline{\mathrm{a}} \mathrm{C}_{2} \mathrm{iC}_{3}$ (measure 3), $\mathrm{yiC}_{1} \mathrm{C}_{2} \mathrm{iC}_{3}$ (measure 4),

${ }^{12}$ azrag lit. "blue" is often used euphemistically for "black".

${ }^{13}$ In MzA axadar was also recorded in the meaning of "wet", as in iw hü yğ́y migir kidiyyih b ídāduh ... iw ğilduh 'ilēh, l issā' axadar hü "and he comes running like this with his (diving) gear ... with his diving suit (lit. skin) on, still wet he was...".

${ }^{14}$ See remarks in Blanc 1970:16 [127]!

${ }^{15}$ lagg, ylugg is listed as "snatch, grab" in Stewart 1990:245 (glossary), but my recording calls for a translation like "hit, strike", as in [alğarrah byirikdūha èh?] $f$ ššamš, itlugg fiha ššams "[they place the earthenware pot where?] in the sun, [where] the sun hits (i.e. shines on) it" as a method to let milk ferment to produce rāyib.

${ }^{16}$ The verb wašš, ywi ${ }^{2} \check{s}$ is onomatopaeic. 
yinC $\mathrm{iC}_{2} \mathrm{iC}_{3}$ (measure $n-1$ ) and $\mathrm{yiC}_{1} \mathrm{tiC}_{2} \mathrm{iC}_{3}{ }^{17}$ (measure $1-t$ ) and yistaC $\mathrm{C}_{2} \mathrm{iC}_{3}$ (measure $i s t a-1)$. Other examples are the active participles of the measures: $\mathrm{C}_{1} \overline{\mathrm{a}} \mathrm{C}_{2} \mathrm{iC} \mathrm{C}_{3}$ (measure 1), $\mathrm{mC}_{1} \mathrm{aC}_{2} \mathrm{C}_{2} \mathrm{iC}_{3}$ (measure 2), $\mathrm{mC}_{1} \overline{\mathrm{a}} \mathrm{C}_{2} \mathrm{iC} \mathrm{C}_{3}$ (measure 3) and $\operatorname{miC}_{1} \mathrm{C}_{2} \mathrm{iC}_{3}$ (measure 4), $\operatorname{mtaC}_{1} \mathrm{aC}_{2} \mathrm{C}_{2} \mathrm{iC}_{3}$ (measure ta-2), mtaC $\bar{a} \mathrm{C}_{2} \mathrm{iC}_{3}$ (measure $t a-3$ ), minC $\mathrm{iC}_{2} \mathrm{iC}_{3}$ (measure $\left.n-1\right), \operatorname{miC}_{1} \mathrm{tiC}_{2} \mathrm{iC}_{3}$ (measure $\left.1-t\right)^{18}$ and mistaC $_{1} \mathrm{C}_{2} \mathrm{iC}_{3}$ (measure ista-1).

An exception to such morphological conditioning is found in forms coloured by the strong velarization caused by the pronominal suffix $-k$ or $-u k$, as in tušgúlk "she occupies you/keeps you busy" and also the vowel of the fem. morpheme in construct state may be affected, as in nuxrút $t^{u} k$ "your (sg. masc.) nose", contrasting with nuxrít'k "your (sg. fem.) nose".

\subsubsection{Allophones of short vowels}

Allophones of short vowels do not differ much from what was described for group I in De Jong 2000:74-77, although some allophones, notably of /a/, may appear in environments different-or are more frequent, or less frequent-from those in group I.

\subsection{Allophones of /i/}

When in stressed and neutral positions, short high vowel /i/ will be realized near I.P.A. [1] and slightly higher nearer to [i] when it precedes $y$, e.g. židd [3ıd:] "grandfather", nirmiy ['nırmi' ${ }^{y}$ "we throw" and dišbih ['dıfbli ${ }^{\mathrm{h}}$ " cold (disease)".

When in velarized positions, backing and centralizing takes place, resulting in [ $\mathbf{t}$, e.g. tibb "(practicing) medicine" [tłb:].

When laryngeals precede, they usually have a lowering effect on $/ \mathrm{i} /$, resulting in [e] or slightly higher, e.g. hiluw \# ['heluw ] "beautiful, sweet", xirm [xerm] "large species of fish".

\subsection{Allophones of $/ u$ /}

In neutral positions short high vowel /u/ will be realized near I.P.A. [v], and slightly higher [u] when it precedes $w$, e.g. yuskun ['joskon] "he lives (inhabits)", nāmuw "they slept" ['næ:mu' ${ }^{19}$

When velarized consonants or laryngeals precede, lowering tends to take place, resulting in a realization near I.P.A. [o], e.g. gumsih ['yomsi ${ }^{\mathrm{h}}$ ] "food dip", hurmah ['horma $\left.{ }^{\mathrm{h}}\right]$ "woman", xuțah ['xotwa ${ }^{\mathrm{h}}$ "step".

\footnotetext{
${ }_{17}$ See following fn.

${ }_{18}$ When in closed syllable, the vowel preceding $\mathrm{C}_{2}$ will be $a$ in measures $n-1$ and $1-t$ (or VII and VIII resp.), e.g. yindarbuw "they are beaten" and mindarbah "having been beaten (sg. fem.)" and yištaglin "they (fem.) work" and mištaġlìn "working (pl. masc.)".

${ }_{19}$ On the articulatory position of [æ] see remark in De Jong 2000:59-6o, fn 10.
} 


\subsection{Allophones of $/ a /$}

1.2.3.4.3.1. /a/ in non-raised positions.

The realization of short low vowel /a/ in neutral environments will be near I.P.A. [e], e.g. tánam ['tenem] "you sleep", maddat ['med:et] "she stretched out".

Where pharyngeals precede, /a/ has a realization near open and front I.P.A. [a], e.g. harìm [ha'ri:m] "womenfolk", 'arǧ́́y [ 'ar'dziy] "lame, limping (sg. fem.)" and also with $h$ preceding, as in šahabíy [ Jaha'biy] "graycoloured (sg. fem.)".

In velarized environments, /a/ is realized near I.P.A. [a], e.g. bahar ['baћar] "sea" and nugțah ['nogłah] "police post" and habșah ['habsah] "severe cold (disease)".

1.2.3.4.3.2. Raising of $\left(^{*}\right) / \mathrm{a} /$ preceding long stressed vowels

The short vowel /a/ is raised in a variety of positions preceding stress:

- preceding stressed Cī: kibīr "large; old", šidìd "strong", gilị̀ "fat, thick", xifíf "light", 'irīs "bridegroom", hirìd "parrot fish", and also 'Ilíy "male given name * $A l \bar{\imath}$ " and verb forms nisīt "I forgot", ligit "I found". Instances of $a$ preceding stressed CCī were not recorded: batțīx "watermelon", sab'in "seventy".

- (preceding stressed Cē): 'ilēh "on him", ligèna "we found", mišèt "I walked", bidēna "we started", (preceding CCē) middèt "I stretched", suwwèt "I did/made" and istinnēni(\#) "we waited" (but istanna "he waited").

- (preceding stressed Cā): 'isākir "soldiers", zimān "in the old days (used as adverb)", timānyih "eight"; (preceding stressed CCā): riǧğ $\bar{a} l$ "man", siyyād "fisherman", kiššā $f$ "search light", bițțāriyyih "flashlight", zirgā "blue (sg. fem.)". mirṛāt "times", mínāt (hâăgih) "the meaning (of sth)".

- (preceding stressed $\bar{u})$ : 'urūs "groom", isSu'ūdiyyih "Saudi Arabia", šu'ūr "emperor (fish species)". ${ }^{20}$

- (preceding stressed a): ǧimál "camels", gi adna "we sat down", xubár "information", nihábuk, "he plundered you".

- (preceding stressed u): kubúr "he grew", gulúd "he grew fat".

- (preceding stressed $i$ ): širíb "he drank", biríy "innocent", guwíy "strong”.

${ }^{20}$ Of the Lethrinidae: the longnosed emperor is Lethrinus olivaceus. 
Raising of $a$ also takes place following stressed $a$, as in ánwikal "it was eaten", áttifag "he agreed", háwǧisat "she improvised song", ánnixal "the palmtrees", álhiwi' "the wind", ál 'iši "the dinner" and ádduwa" "the medicine".

Also when $a$ follows stressed $i$ in closed syllable, it is raised, as in yíndirib "he is beaten", yíttifig "he agrees". ${ }^{21}$

1.2.3.4.3.3. Raising of the feminine morpheme $(\mathrm{T})$

The $a$ of the fem. morpheme is regularly raised in neutral environments and reaches a phonetic value near I.P.A. [lh]. This is not only a pausal phenomenon, but occurs sentence-medial as well. Examples are kull wāhid 'induh xurrāâfah hilwih biyğibhi' "everyone has a nice story which he tells", lamma llēlih gōtarat "until the evening has passed", țalla' gișìdih $f i$ wihdih rāayidhi" "he recited a poem on a girl with whom he was in love".

In velarized environments such raising does not take place, e.g. gāmat ḥuṛ̣ah \# "a woman stood up", (a mock rhyme) binğīb lēna fạxxah siminih, iw līhiy siminih bi lmarrah "we get for ourselves a fat chicken, but it is not fat at all". Other examples are: bisițah "simple", gilì ¿igāmah "snake-like species of sea fish", ramlah "sand".

Raising is not inhibited by the pharyngeals "and $h$, e.g. rfayy ih "thin", sām ih "hearing (sg. fem.)", Șuwālhị "name of a tribe", mirḡẹḥih "swing", safịih "cannister (of 20 litres)".

1.2.3.5. Prosodic lengthening of short vowels

To express extra emphasis, such as on long durations of time, long distances or great quantities, speakers often prosodically lengthen short (but also long, see 1.2.4.7.) vowels. Examples are bti'gluh 'ala lmayyih "you boil it (for a long time) in water", iw bingațtiy lhațab buh ku:llïtuh "we cover a:ll the firewood with it".

\subsubsection{Long vowels and diphthongs}

\subsubsection{Monophthongization of diphthongs *ay and *aw}

In positions not influenced by velarization, or preceded by $\mathrm{X}$, older diphthongs *ay and *aw have in most cases become monophthongal $\bar{e}$ and $\bar{o}$.

${ }^{21}$ In verb forms like hawǧisat and yíndirib and yíttifig, the raised $a$ will again surface as $a$ when it is in closed syllables, e.g. hawğast "I improvised song", yindarbuw "they are beaten" and yittafguw "they agree" (see also 3.2.3.1.1. and 3.2.3.3.1.). 
Examples for *ay are: itnēn "two", bèn "between", lèlih "evening”, sēl "flood", ğwēl (dim. to ǧăl) "little side" and examples for $\bar{o}: m \bar{t} t$ "death", yōm "day", fōg "above”, sōdíy "black (sg. fem.)", gōmah “(manner of) standing up".

In some cases such monophthongization in neutral environments has not taken place, mawğūd "present (adj.)", aw'a "watch out!"22 and also taybis "drying".

In forms like b'aytarāan velarization has also spread backwards, preserving ay as a diphthong. Diphtongal *aw is preserved by spread of velarization as aw or ow in e.g. gowtaruw "they went".

In MzA (of 'Ayn Hud $r^{2} h^{23}$ and of a family in Wādiy 'Arādah) forms like $m \bar{e} g \bar{u} d$ "present" and $m \bar{e} l \bar{u} d$ "born" have also been recorded.

\subsubsection{Isolating long vowels $/ \bar{\imath} /, / \bar{u} /, / \bar{a} /, / \bar{e} /$ and $/ \bar{o} /$ as phonemes}

In many dialects of group I phonetic overlapping of $/ \overline{\mathrm{e}} /$ and $/ \overline{\mathrm{i}} /$ in neutral environments occurs. Such is not the case in MzA and BWA. Finding (near) minimal pairs to isolate these phonemes is not a problem:

$d \bar{e} r$ "monastery" — dīr "turn (trans.)!"—dūr "turn (intrans.)!" — dōr "floor (in a building)"-dār "house"

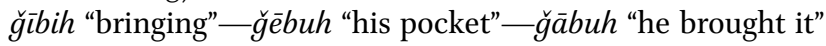
gōm "enemy tribe"—gūm "get up!"

Suffixed prepositions lay "to me", 'aláy "on me" and fay "in me" are actually better interpreted as final $-a y+y$.

\subsubsection{Allophones of $\overline{\mathrm{a}}$}

Like in the dialect of the Tarābīn of group I, $\bar{a}$ in neutral surroundings is realized as near I.P.A. [ع:]. Unlike Turbāniy, however, $\bar{a}$ in open syllable and neutral surroundings does not need $\mathrm{Ci}$ following within morpheme boundaries for such I.P.A. values to be reached.

In MzA this [ $\left.\varepsilon^{\prime}\right]$ for $\bar{a}$ is reached also when $\bar{a} C$ is morpheme-final, e.g. kțärr "many (pl. com.)", šgäg "compartments of the tent", ḩbä́l "ropes", šäših "screen" and also wäḥid "one", särḥih "out grazing (goats and sheep) (sg. fem.)", nä̈gtī "my she-camel”.

\footnotetext{
${ }^{22} a w^{\prime} a$ is often left unconjugated, and has thus developed into a general particle of warning or admonition, as in aw'a tans! "don't you forget!"

${ }^{23}$ Von Oppenheim 1942:159 mentions 'Ayn Ḥựrah as 'Lēgiy territory (in his transcription: 'Olēkāât). Today this oasis is inhabited by members of the Mzēnah.
} 


\subsubsection{Reflexes of final *āa( $\left.{ }^{2}\right)$}

Like in the dialect of Biliy in the north, ${ }^{24}$ the reflex of final ${ }^{*}-\bar{a}$ in neutral environments in MzA and BWA is often -i". Examples are: Wādiy Sli" "Wadi

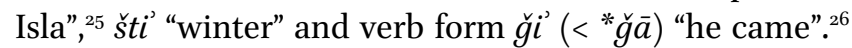

Final $-i$ ' will be unstressed when a heavy sequence precedes. The vowel of the heavy sequence is then stressed. E.g. áššifi "the curing", (wāhid) mínni "(one) of us", táfdi" "you sacrifice" and yánsi "he forgets".

However, in sg. fem. forms (cf. MSA CaCCā') that come with the (sg. masc.) aCCaC pattern for physical defects and colours, we do find raising like in group I, e.g.: šadf’́y "left-handed (sg. fem.)", hawlíy "cross-eyed" and habliy "stupid", unless such raising is prevented by phonetic factors, such as velarization, as in e.g. (colours) samrā "brown", xadrā "green", hamrāa "red", zargā "black; blue” and (physical defects) 'iwrā "one-eyed”, gir' $\bar{a}$ "bald" and dora "absent minded". The final stressed - $\bar{a}$ may be cut off in pause by a flottal stop, e.g. xadră \#.

\section{N.B. "here" is niha $\bar{a}($ ') in MzA and BWA.}

In dialects of group I raising (there to final -íy) is inhibited by (underlying) $a$ preceding in open syllable. ${ }^{27}$ Such is not the case in MzA and BWA, e.g. hiwi "wind", 'iši "dinner", diwi "medicine" (in MzA), simì "heaven" and also verb forms like miší (< *mašā) "he went", ligi" (< *lagā) "he found" and tawaffi" "he died".

When (secondary) emphatics precede, final ${ }^{*}-\bar{a}\left({ }^{\prime}\right)$ is not raised, while reflexes of ${ }^{*}-\bar{a}^{3}$ have remained long and reflexes of ${ }^{*}-\bar{a}$ are short. Examples

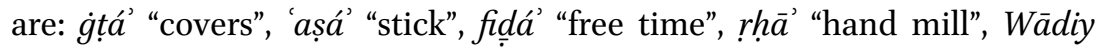

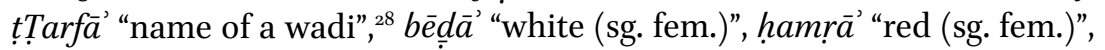
$x a \underline{d} r \bar{a}$ ' "green (sg. fem.)", gawá "flirting”, duwá "medicine" (in BWA, but in MzA diwi'), ragt tă "speckled (sg. fem.)", zarga $\vec{a}^{\prime}$ "black; blue; dark coloured (sg. fem.)", samrā' "brown (sg. fem.)".

In BWA álma( $\left.{ }^{\prime}\right)$ "the water" and in MzA álmi were recorded for "the water" ( in both with much more frequent mayyih).

\footnotetext{
${ }^{24}$ See De Jong 2000:81.

${ }^{25}$ My Turbāniy informant pronounced Wädiy Sliy. The name of this wadi is often spelled ' Isla ' on maps (cf. 1.2.4.4. and 3.1.5.). The wadi is located somewhat to the southeast of at-Ṭur, where it disappears into the south-western high mountains.

${ }^{26}$ Like in the dialect of Biliy in the north, see De Jong 2000:83.

${ }_{27}$ See Blanc 1970:12 [123] and De Jong 2000:82.

${ }^{28}$ The wadi is situated at the far high end of Wādiy Fērān in central Sinai and is Ğbāliy territory bordering on Mzēniy territory.
} 
Final * $-\bar{a}$ is not raised in the elative aḥla "sweeter; more beautiful".

Several of the preceding examples also show raising of final $-\bar{a}$, although preceded by $a$ in open syllable, does take place, ${ }^{29}$ e.g. duwá or diwi $\iota^{\prime}$ and verb forms like miší and ligí.

The forms with raised final ${ }^{*}-\bar{a}(>-i)$ do not only occur in pause, but also in sentence-medial positions. Such raising is therefore concluded to have led to morphological restructuring.

The-usually unreleased-glottal stop following the final vowel is not only highly regular when this vowel is stressed, but also when it is unstressed.

In MzA forms like ğ $\bar{a} n \bar{i}$ "he came to me" were heard, but also forms with lengthened [1] , as in $h \bar{u} g{ }_{g} i^{u} k$ "he came to you (sg. masc.)": not with IPA [i:], but with lengthened [1]: [dzir $\left.{ }^{\mathrm{u}} \mathrm{k}\right]$ ) "he came to you (sg. masc.)" and also $h \bar{u}$ ği:k (IPA [dzı:k]) "he came to you (sg. fem.)". In BWA such lengthened [1:] was not heard.

\subsubsection{Allophones of long vowels $\overline{\mathrm{e}}, \overline{\mathrm{i}}, \overline{\mathrm{o}}$, and $\overline{\mathrm{u}}$}

\subsection{Lowering effect of preceding emphatics on $\overline{\mathrm{i}}$ and $\overline{\mathrm{u}}$}

Like in group I (see De Jong 2000:85), primary and secondary emphatics will lower the phonetic value of following $\bar{l}$ and $\bar{u}$ towards (resp.) I.P.A. [e:] and [o:]. Such lowering is clearer in the case of following $\bar{u}$; with following $\bar{\imath}$ it is less clear, but an on-glide is apparent.

Like in group I, reflexes of *ay and *aw following emphatics have remained diphthongal, which prevents homophonic clash with lowered $\bar{\imath}$ and $\bar{u}$ in positions preceded by emphatics.

\subsection{Off-glide in $\overline{\mathrm{e}}$ and $\overline{\mathrm{i}}$}

An off-glide in the realisation of $\bar{e}$ and $\bar{l}$ is often audible, when these are followed by an emphatic. Examples are (from both dialects) gēd (I.P.A. [ge: ${ }^{a} \oslash$ ] "chain", (a less clearly audible off-glide in) Fērāan [fe: ${ }^{a^{\prime}}$ ra:n] "Wadi

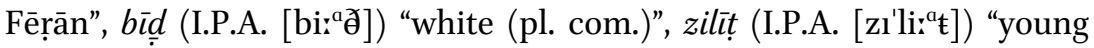
goat or gazelle" and mšêtah [\# Pəm' $\int \mathrm{e}^{\mathrm{a}^{\mathrm{a}}} \mathrm{ta}^{\mathrm{h}}$ ] "type of herb".

Comparable off-glides, but then towards I.P.A. [a], are heard when $h$ or "follow $\bar{e}$ or $\bar{\imath}$, e.g. ğinnēhhih I.P.A. [dzı'ne:ahe ${ }^{\mathrm{h}}$ ] "brown surgeonfish", ${ }^{30} b \bar{e}^{-\mathrm{c}}$

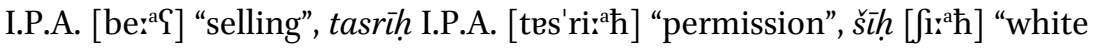

${ }^{29}$ Which is also the case in the dialect of Biliy, see De Jong 2000:82 (1.2.4.4.3.2.).

${ }^{30}$ Lat. Acanthurus nigrofuscus. 


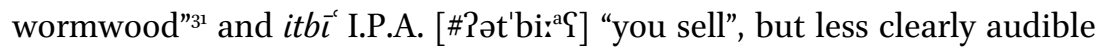

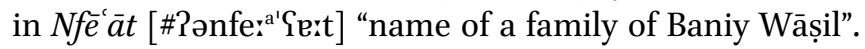

\subsection{Off-glide in $\overline{\mathrm{o}}$ and $\overline{\mathrm{u}}$}

Like in group I off-glides towards I.P.A. [a] are audible in $\bar{o}$ and $\bar{u}$ when these are followed by emphatics, e.g. gōtarat ['go: atarat] "she went".

Off-glides in $\bar{o}$ and $\bar{u}$ towards I.P.A. [a] are clear when 'or $h$ follow, e.g. $n \bar{o}^{c}\left[\right.$ no: $\left.^{\mathrm{a}}{ }^{\mathrm{C}}\right]$ "type, sort", ğ $\bar{u}^{c}$ I.P.A. [dzu: $\left.{ }^{\mathrm{a}} \mathrm{c}\right]$ "famine", misūh [mə'su: $\mathrm{a}$ ] "milk camel" (there were no instances recorded with $\bar{o}$ followed by $h$, but e.g. lōh "(wooden) board, panel" would thus be [lo: $\mathrm{a}]$ ).

\subsubsection{Diphthongs}

MzA and BWA have four diphthongs: $a y, a w, i y$ and $u w$.

1.2.4.6.1. Reflexes of *ay and *aw

1.2.4.6.1.1. Reflexes of *ay and *aw in neutral environments

In positions not preceded by or velarized consonants *aw and *ay have usually become $\bar{o}$ and $\bar{e}$.

1.2.4.6.1.2. Reflexes of *ay and *aw in non-neutral environments

1.2.4.6.1.2.1. Reflexes of *ay and *aw preceded by $X$

Like in group I, MzA and BWA have phonologically conditioned diphthongs for * $a w$ and *ay in positions preceded by back spirants $X$ (i.e. $x, \dot{g}, h$, ' and $h$. For the latter, see remark below). In some instances, a diphthong is audible without being attributable to phonetic conditioning, as in sanatayn "two years" (MzA).

Examples with $X$ preceding *ay are: xayt "thread", gayrī "(someone) other than I", $b$ ilhayl "very", 'ayn "eye", but the only form with preceding $h$ recorded is $n h \bar{e} d i h$ "a type of herb (used to treat kidney disease)".$^{2}$

Examples with $X$ preceding *aw are: xawf "fear", hawl "year", 'Awdih "male given name" and a Bedouin verb ${ }^{33}$ hawğas, yhawğis "improvise singing", hawmal, yhawmil "bring a hamülah ${ }^{34}$ for a feast".

\footnotetext{
${ }^{31}$ Lat. Artemisia herba-alba, used to prepare samn šịiy "ghee".

$3^{2}$ Perhaps the reference was to the Eyptian desert weed Cymbopogon proximus.

33 Verbs of the type CawCaC, yCawCiC (with inserted $w \bar{a} w$ ) are considered to be typically Bedouin, see Palva 1991:155.

${ }^{34}$ A hamūlah is an "animal led to a party to be slaughtered as a present".
} 
1.2.4.6.1.2.2. Diphthongs *ay and *aw preceded by velarized consonants Examples of *ay with a velarized consonant preceding: sayf "summer", dayf "guest", hatțayt "I put (perfect)". Examples with the secondarily velarized consonants preceding are: ištarayt "I bought", ihmarrayt "I turned red", taharrayna $\bar{a}^{u} k$ "we waited for you", kitrayš? "how much?", $\underline{\text { dall }}$ layna "we remained" and also șannayt ${ }^{35}$ "I kept quiet", dawayt $^{36}$ "I returned home at sunset (with goats and sheep)" and tarabayzih "table". ${ }^{37}$

Examples of * aw with a velarized consonant preceding are fewer: șawm

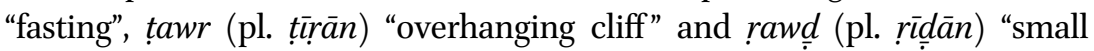
wadi".

1.2.4.6.1.2.3. Reduction of diphthongs ay and aw

The diphthong in $\dot{g} a y r$ is often reduced to $a$ and then complementary lengthened. Examples are: $\dot{g} \bar{a} r$ ánnaxal, mā fih izrā'ah zamān "only palm trees, there was no agriculture in the past" and 'ašān law daggat wāhid minni', $\dot{g} \bar{a} r$ kān iyrawwih l ittaktūr ${ }^{3}{ }^{8}$ "because if it would sting one of us, he would have to go to the doctor".

Diphthongs are much less regularly than in group I reduced to $a$ or $\bar{a}$.

'Systemzwang' has preserved diphthongs in e.g. taybīs "drying (measure 2 verbal noun)" (but not in the imperfect form of measure 1 yébas "it (masc.) dries"), šawliy "left-handed (sg. fem.)" and mawğūd "present (adj.)". Another instance may be aw'a "beware, watch out!" (other imperatives of primae $w \bar{a} w$ verbs are with initial $\bar{o}$ : ogaf! "stand still!”, òrid! “fetch water!”).

\subsection{Diphthongs -iy and -uw}

\subsection{Reflexes of final *-ī and *-ù}

Final diphthongs $-i y$ and $-u w$, which in part reflect older final ${ }^{*}-\bar{\imath}$ and ${ }^{*}-\bar{u}$ are best heard in lento speech and occur both in sentence medial as well as in sentence final positions.

In verbs the ending $-u w$ has developed as a morpheme signalling pl. masc., but also in pronominal suffixes. Examples are: (verbal perfect)

35 In this example, velarization caused by șād is carried through the word by $n n$, which then causes the dipthongal realization in the final syllable.

${ }^{36}$ dawá, yidwiy is a measure 1 verb in MzA and BWA. In several group I dialects it is measure 4 ad $w a$, yiḍwiy.

${ }_{37}$ The latter does not reflect Older Arabic ay, but is a loan-perhaps via Cairene-from Greek $\tau \rho \alpha \dot{\pi} \varepsilon \zeta \alpha$. In e.g. TAS the diphthong is not present: there tarabēzah.

${ }^{38}$ taktūr "doctor" (cf. Cairene daktūr, see Hinds and Badawi 1986) was also recorded in TyA, see Shawarbah 2007:419. A comparable example there is taftar "notebook" (cf. Cairene daftar, see Hinds and Badawi 1986). 
katab-uw "they wrote", katabt-uw "you (pl. masc.) wrote", (verbal imperfect) yikitb-uw "they (pl. masc.) write", tíkitb-uw "you (pl. masc.) write" and in pronominal suffixes bēth-uw "their (pl. masc.) house" and bētk-uw "your (pl. masc.) house". ${ }^{39}$

Anaptyxis may also create final $-u w$ to eliminate final -CC clusters, e.g. hiluw \# "pretty, beautiful" (morphological base hilw) and daluw \# "pail" (morphological base dalw).

Instances of final -iy are much more numerous. Examples of verbal endings are (perfect) katabt-iy "you (sg. fem.) wrote" and (imperfect) tíkitb-iy "you (sg. fem.) write". In verbs where $\mathrm{C}_{3}=y$ (imperfect) yimšiy "he walks", ysawwiy "he makes" and yiğı́y "he comes", etc.

In MzA and BWA an -iy ending in the 3 rd p. sg. masc. of $i$-type perfects is rare. Instead, final $y$ verbs nearly all have an $a$-type perfect e.g. nisi" "he forgot" ${ }^{40}$ Final $-i y$ may also reflect older final * $-\vec{a}$, as in (MzA) miy "water", (reflecting the sg. fem. pattern *CaCCā' for physical defects) 'arğ́y "limping (sg. fem.)", habliy "simple-minded (sg. fem.)", 'amyíy "blind" and the sg. fem. pattern for colours (also *CaCCā') sawdíy "black", šahabíy "sand-coloured". Although a regular reflex for final ${ }^{*}-\bar{a}$ is stressed $-i \bar{i},-i y$ reflects ${ }^{*}-\bar{a}$ in hniy ${ }^{41}$ "here" (in BWA only; "here" is nih $\bar{a}(-n i y)$ in MzA). Final $-\dot{i y}$ reflects final * $\vec{\imath}$ in biríy "innocent", final *-ly in șibíy "boy", *-ay' in šiy "thing” and is of course also the nisba ending for the sg. masc., e.g. Mașriy "Egyptian".

Anaptyxis may also create final (but unstressed) -iy sequences, as in e.g. ‘miy \# "(pl. com.) blind" (morphological base ‘my) and ğidiy \# "billy goat" (morphological base ğidy).

\subsubsection{Prosodic lengthening of long vowels and diphthongs}

The first element of the diphthong ay is often lengthened, ${ }^{42}$ e.g. 'aryš "bread", 'a:yb "disgraceful act", xa:ytni' "our (fishing) line". Such lengthening of diphthongs is also heard in some of the dialects of group I (TAN, TAȘ, Ḥ̂A, ĞrA and BdA, see chapter III) and also takes place without an apparent intention to express extra emphasis. ${ }^{43}$

\footnotetext{
39 For further detail on the development of $-u w$ in pronominal suffixes, see 3.1.12.2.

$4^{40}$ Although labelling the form nisí as an $a$-type perfect may look like a contradiction, the interpretation of nisi" < *nasa (after applying the rule described for raising of final ${ }^{*}-\bar{a}$, and subsequently the rule for raising of short $a$ in open pre-stress syllable) is plausible (see remark ${ }^{*_{1}}$ in $3 \cdot 2.2 \cdot 5 \cdot 1$.).

${ }_{41}$ Final stressed $-i y$ for * $-\bar{a}$ is regular in group I. In the dialect of Biliy, however, the same $-i$ reflex was recorded for ${ }^{*}-\bar{a}$ and also ${ }^{*}-\vec{a}$, see De Jong 2000:89.

${ }^{42}$ This was not observed with the diphthong aw, but this may be due to the fact that aw occurs much less frequently than $a y$.

43 Lengthening of diphthongs was also reported to be a feature of the dialect of the Dawāğrah in northern Sinai, see De Jong 2000:420-421.
} 


\section{Stress AND Phonotactics}

\subsection{Stress}

\subsubsection{Rules for word-stress}

In terms of rule order, the rule for word stress follows the rule for elision, but precedes the rule for anaptyxis. Stress is of the máktabah-type. Verbal gahawah-forms of the $i$-type imperfect, like yáhartuw "they plough", receive special treatment (see 2.1.2.4.).

Rules for word-stress are:

1) Speech pause does not have the function of a consonant for the stress rule.

2) The domain of stress is formed by:

a.) either the last three syllables of a word, including the article $a l$ - or $i l$ - and the verbal an- prefix of measure $n$ - 1 and the syllable preceding the $t$-infix of measure 1 - $t$ and suffixes, if these are part of the last three syllables,

b.) or, in the absence of an article, infix or prefix, the last four syllables.

3) Stress is placed according to the criterion of quantity, i.e. vowels of heavy sequences are stressed.

4) The following types of 'heavy' sequences occur: vCC $(C)$ and $\bar{v} C(C)$ (including $\overline{\mathrm{v}}(\mathrm{h})$ ).

5) The vowel of the first heavy sequence from the right is stressed (see examples in 2.1.1.1.).

6) In the absence of a heavy syllable, stress the vowel in the first syllable from the left if more than two syllables are available, otherwise stress the last syllable.

An exception may be made when of four syllables the first three syllables are open and contain $a$, and the last syllable is not heavy, i.e. $\mathrm{CaCaCaCv}(\mathrm{C})$. In that case the sequence maybe resyllabified as $\operatorname{CaCCiCv}(\mathrm{C})$ and is stressed on the first syllable: $\operatorname{CáCCiCv}(\mathrm{C})$, e.g. dárbituh "she hit him" and rágbituh "his neck". This type of resyllabification was recorded in MzA, but not in BWA.

Also if resyllabification is absent, the first syllable is stressed: $\mathrm{CáCaCaCv}(\mathrm{C})$, e.g. dárabatuh and rágabatuh.

2.1.1.1. Stress in words with heavy sequences

Examples of stress in words with 'heavy' sequences are: mádrasih "school", áštaġl "he worked", áttifag "he agreed", ánġasal "he was washed", álbuṣal 
"the onions", álwalad "the boy/son", iššti "the winter", il 'iši "the dinner", ${ }^{44}$ árrkab "the knees", áligṃam "the Moray eels", álibkal 45 "the jerrycans", ilihssily "the rocks" (in the latter two examples anaptyctics are underlined) and šawlíy "left-handed (sg. fem.)", šahabíy "sand-coloured (sg. fem.)", țilína "we rose", waládk "your (sg. masc.) son", waládk "your (sg. fem.) son", áṃmuk "your mother" (MzA), štì "winter", zèn "good”, zēnih "good (sg. fem.)", zēnin "good (pl. masc.)".

2.1.1.2. Examples of stress in words without heavy sequences

\subsection{Stress in $\operatorname{Cv} C v C(v)$}

Stress in $(\mathrm{C}) \mathrm{v} \mathrm{Cv}(\mathrm{C})^{46}$ is placed thus:

(') ${ }_{1}$ CvC: akál "he ate", axád "he took", ugúm "stand up!", iğíy "I come" $\operatorname{Cv}_{1} \operatorname{Cv}\left({ }^{\prime}\right)$ : 'așá "stick", 'iší "dinner", miší "he walked", duwá "medicine" $(\sim$ diwi $)$.

Cv CvC: ǧimál "camels", šiǧár "trees", gițás "he dived"; wugáf "he stood up", warág "paper" and yiğ́y "he goes", șibíy "boy", biríy "innocent", țiríy "moist; soft".

\subsection{Stress in $(C) v C v C v(C)$ and $(C) v C v C v C v(C)$}

Examples of stress in $(\mathrm{C}) \mathrm{vCvCv}(\mathrm{C})$ sequences are:

(C) $\operatorname{vev} C v(C)$ : ákalat "she ate", (gahawah-form) áhamar "red", xášabih "piece of firewood", dárabuw "they hit (perfect)", báladuh "his country", násatuh "she forgot him" and gahawah-forms gáhawah "coffee", náaǧih "ewe", áhariț "I plough" and yágațis "he dives".

(C) $\operatorname{vev} \operatorname{CvCv}(\mathrm{C})$ : ákalatuh "she ate it" (or MzA áklituh), dárabatuh "she hit him" (or MzA ḍárbituh), fárašatuh "she spread it (sg. masc.) out" (or MzA fáršituh), rágabatuh "his neck" (or MzA rágbituh) and gahawah-forms gáhawatuh "his coffee" (or MzA gáhwituh), láhamatuh "his (piece of) meat" (or MzA láḥmituh), tá aragin "you (pl. fem.) sweat", yáa araguw "they sweat".

alxášabih "the piece of firewood", albádawiy "the Bedouin (sg.)", (gahawahform) annáxalah "the palm tree", (gahawah-form) ibtáhafruw "they dig", ištágalat "she worked", inbáṣațuw "they rejoiced", ittáfagat "she agreed", tiǧáwwazat "she got married", takállamuw "they spoke".

\footnotetext{
44 But notice $a$ in the article in áššifi "the healing".

45 The word buklah (pl. bkal) is used for a plastic jerrycan in MzA.

${ }^{46}$ When $v_{1}$ in this pattern is not preceded by $C$, it is underlying $|a|$.
} 


\subsubsection{Exceptions to the stress rule}

\subsubsection{Stress on reflexes of ${ }^{*}-\vec{a}^{\prime}$ and ${ }^{*}-\bar{a}$}

Reflexes of ${ }^{*}-\vec{a}$, which have not been raised (see 1.2.4.4. above), will be stressed, when they have remained long and thus form a heavy sequence, e.g. $x a \underline{d} r \bar{a}$ "green (sg. fem.)", șifrā "yellow (sg. fem.)", bẹ $\underline{d} \bar{a}$ "white (sg. fem.)", gir 'ā "bald (sg. fem.)", 'iwrā "one-eyed (sg. fem.)".

In positions not influenced by velarization, $-\vec{a}$ is raised to -iy (see 1.2.4.4.) Such raised -iy reflexes are then stressed, even if (other) heavy sequences precede, e.g. sōdíy "black (sg. fem.)", šadfı́y "left-handed (sg. fem.)", hawliy "cross-eyed (sg. fem.)" and hniy "here" (only in BWA), although more regular for "here" is nihā.

Also in a gahawah-form, in which the gahawah-vowel has resolved the cluster forming the heavy sequence, the reflex of $-\vec{a}$ receives stress: $(\check{s} a h b b \vec{a}>)$ šạabíy "sand coloured (sg. fem.)".

Reflexes of final * $\bar{a}$ in neutral environments are final $-i$. The resulting forms are then stressed in conformity to the rules in 2.1.1.2. Examples are šti "winter; rain", mi "water", wādiy Sli' "wadi Isla", simì "sky", diwì "medicine", 'iší "lunch", sifi "healing”, mášti "winter".

Examples of pronominal suffixes *-hā and *-nā are tanshi! "forget her!",

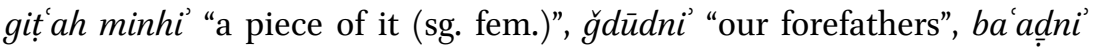
"(we) each other" and of the sg. masc. demonstrative álwalad di' "this boy". When velarization has spread, $a$ in pronominal suffixes is not raised, e.g. uxūha' "her brother", binzabbițha' "we do it (sg. fem.) properly".

Examples of such raising in verb forms in which $\mathrm{C}_{3}=y$ are (perfect) miši" "he walked", ligi" "he found", sawwi "he did" and ǧi "he came". Examples of imperfect forms are yansi" "he forgets", ytagaddi" "he has lunch".

Examples of reflexes of ${ }^{*}-\bar{a}$ preceded by velarized consonants are álgada' "type of wood (does not burn like embers)", barrra' "outside", verb forms (imperfect) yard $a^{3}$ "he agrees happily" and șa!lla' "he prayed".

2.1.2.2. Stress on final nominal *-y reflexes in ${ }^{*} \mathrm{CaC} \bar{\imath} y$

In MzA and BWA, reflexes of the pattern CaCiy are CaCiy or (after raising the short vowel $a$ ) CiCiy and are stressed on the ultimate, which is in conformity with the rules formulated in 2.1.1.2.

2.1.2.3. Stress in $\mathrm{al} / \mathrm{il}+{ }^{*} \mathrm{CaC} \bar{y}$

When the article precedes a reflex of $\mathrm{CaC} \bar{y} y$, the resulting cluster will draw stress onto its directly preceding vowel, e.g. innibiy "the Prophet" and ișşibiy "the boy". 


\subsubsection{Stress in suffixed gahawah-forms}

In forms with consonant-initial suffixes closing the syllable with the gahawah-vowel, this vowel is stressed, e.g. ba ádhin "each other (pl. fem.)", sahánha "her plate".

With the fem. morpheme becoming -at in construct state, stress is placed according to rules described in 2.1.1.2., e.g. gáhawatuh "his coffee".

In verb forms of $i$ - or $u$-type imperfects, the gahawah-vowel is dropped when vowel-initial suffixes are appended, but stress is not placed on the gahawah-vowel, which then directly precedes the resulting consonant cluster, e.g. yáharțuw "they plough", táağnuh "you knead it (sg. masc.)", yáxabtuw "they knock".

Resyllabified MzA forms of the type CaCaCatv > CaCCitv are stressed on the first syllable; resyllabification of such forms cancels the high-vowel elision rule and the resulting form is stressed according to rules described in 2.1.1.2., e.g. xášbituh ${ }^{8}$ "his piece of wood" (contrast e.g. wákiltuh "eating it (sg. masc.)" and ríkibtuh "his knee").

\subsubsection{Stress in $v C C I C v$}

A short high vowel is not dropped from a sequence in which the consonant preceding it is phonetically close to, or identical with the consonant following it and stress is placed according to rules in 2.1.1.2., e.g. thálliluh "you analyze it", ǧidditī "my grandmother".

\subsubsection{Stress units}

\subsubsection{Stress in combinations with preposition min and negated personal} pronominals

Like in group I, the preposition min may form one stress unit with the following word, as in mín-tahat "from below", min-kidiy "from this" and min-ihniy "from here" (the latter BWA).

For stress in negated personal pronominals, see 3.1.12.1. of this chapter.

\subsubsection{Enclitically suffixed prepositions $\mathrm{l}$ and $\mathrm{b}$}

\subsection{Enclisis of the suffixed preposition 1}

Enclitic suffixation of the preposition $l$ occurs only sporadically. ${ }^{49}$ The examples (all from MzA) are ğă-luk "he came to you", gult-ilhi' "I said to

\footnotetext{
47 I hear sin, rather than șād.

${ }^{48}$ Notice also that the high vowel elision rule is not applied after stress placement, hence xášbituh, not xášibtuh (contrasting with a form like 'ilibtuh "his packet").

49 In as far as such may be concluded; it is not possible to conclude enclitic suffixing
} 
her" (notice that the form is not lēha), ahsál-luk "it is best for you" (assimilated ahsan+luk) and a'míl-luk "I'll make for you". ${ }^{\circ}$

2.1.3.2.2. Enclisis of the suffixed preposition $\mathrm{b}$

Instances of enclitic suffixation of the preposition $b$ were not recorded.

\subsection{Phonotactics}

\subsubsection{The gahawah-syndrome}

2.2.1.1. The gahawah-syndrome: a-insertion in *aXC sequences

The gahawah-syndrome is active in MzA and BWA; $a$ is inserted in a sequence $\mathrm{XC}$ when this sequence is preceded by $a$. The rule is:

$$
\varnothing>\mathrm{a} /(\mathrm{C}) \mathrm{aX} \_\mathrm{C}(\mathrm{V})
$$

$\mathrm{X}=$ any of the back spirants $h, h,{ }^{\prime}, x, \dot{g}$

The resulting vowel may be stressed according to rules described in 2.1.1.2. Exceptions to these rules with regard to stress in gahawah-forms are described in 2.1.2.4. Examples of gahawah-forms are: ("naxl) naxál "palm trees", ( ${ }^{*}$ sahl) sahál "easy", ( *axdar) áxaḍar "green", ( ahțal) áhațal "stu-

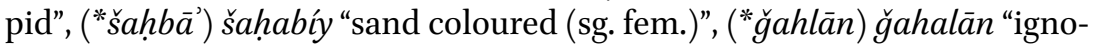
rant", ("mahmūl) mahamūl "neglected", ("maxrūm) maxarūm "pierced", ("mahțūt) mahațūt "placed", ("maxfiy) máxafiy "hidden" and verb forms ( "yaxțib) yáxațib "he proposes (for marriage)", ( "yaḥšūh) yahašūh "they fill it", ("ta'raguw) ta'araguw "you (pl. masc.) sweat".

\subsubsection{Morphological categories showing variation}

Although the gahawah-syndrome is active in forms of the past participle (i.e. where $\mathrm{C}_{1}=\mathrm{X}: \operatorname{maXC}_{2} \overline{\mathrm{u}} \mathrm{C}_{3}$ ) like maxarūm "pierced", mahamūl "neglegted" and ma agū! "reasonable", it was not recorded in maxṣūṣ "specialized" and mahsūb 'ala "reckoned with".

Exceptions are also found with the pattern $\operatorname{maXC}_{2} \mathrm{aC}_{3}(\mathrm{ah})$ : ma'rakah "battle", mahkamah "court of justice", magrib "time of sunset".

from a form gult+luh, since stress does not shift (as in e.g. gālát-luh) and no vowel is lengthened (as in e.g. gă

${ }^{50}$ The verb form must be a loan (an indication is also the initial vowel: a mil instead of i $m i l)$, see also remark in following fn. 
2.2.1.3. Morphological categories in which the gahawah-syndrome is not active

The gahawah-syndrome is not active in derived verbal measures, e.g. (measure 4) a ța "he gave", (measure ista-1) istahmal, yistahmil "bear, endure", istagrab, yistagrib "wonder, be amazed", ista 'mal, yista 'mil "use". Quadriliteral verbs gahwa, yigahwiy "serve coffee or tea to", zagrat, yzagrit "ululate" and a passive participle mgatal "handicapped in the legs" and ta-quadriliteral tagahwa, ytagahwa "be served coffee or tea".

Examples of elatives are ahsan "better", ahla "more beautiful, sweetest", axțar "most dangerous", but ágalad "thicker".

In loans from Standard Arabic (or Cairene Arabic) like mahkamah (see above) the syndrome is not active. Other examples are: ragma 'ann "although", ag̣labiyya "majority", tahliyyih "analysis", mayyah ma daniyyih "mineral water", ya niy "that is, it means", yahșal "it happens" and another measure 1 verb ya'mal ${ }^{51}$ "he makes, does".

The fem. morpheme in construct state becomes -at, also when it follows $\mathrm{XaC}$ (i.e. where $a$ is a gahawah-vowel), so that the sequence CaXaCat is the result. When such a sequence is directly suffixed with a vowel-initial suffix, the CaXaCatv sequence-like any other sequence of the type CaCaCatv-tends to be resyllabified as CaXCitv in MzA.

Examples are naxlitì "my palm tree" and gáhwituh "his coffee". When such resyllabification does not take place, the resulting forms are of the type CaXaCatv, as in e.g. lahamatī "my piece of meat" and dáxanatuh "its (sg. masc.) smoke" (for further details, see 2.1.1.).

2.2.2. Articulatory delay in the realization of alveolar sonorants (liquids $l, r$ and $n$ )

2.2.2.1. Articulatory delay in the realization of $\mathrm{r}$ : the bukara-syndrome Often the 'simple' bukara-syndrome ${ }^{52}$ creates an intrusive vowel in a sequence $C r v$. The vowel created is inserted between $C$ and $r$ and is in phonetic quality guided by the vowel following $r$. A summary of the rule is:

$$
\begin{aligned}
& \varnothing>\mathrm{v}_{\mathrm{b}} /-\mathrm{C}_{-} \mathrm{Rv}_{\mathrm{a}} \\
& \mathrm{v}_{\mathrm{b}}=\mathrm{v}_{\mathrm{a}} \text { or } \mathrm{v}_{\mathrm{b}} \approx \mathrm{v}_{\mathrm{a}} \\
& \mathrm{R}=r \text { or } r \\
& \mathrm{C}=\text { any consonant }
\end{aligned}
$$

${ }^{51}$ Much more current for "make, do" is sawwa, ysawwiy.

$5^{2}$ See also EALL 2006 (Vol. II):320-322. 
Examples of bukara-vowels are (underlined): zağarațat "she ululated", tzagigirit "she ululates", tušurud "she flees", gațarah "drop (noun)", kuburuw "they grew old", tufurukha "you rub it (sg. fem.)".

Examples of the bukara-syndrome inhibiting the elision of a preceding high vowel are: tkassiri isnūn"k. "it (sg. fem.) breaks your teeth", miš gädir iy ğ $b$ "he is not able to bring".

Examples of the 'greater' or 'expanded' bukara-syndrome creating vowels: mitị iw nuṣs "a meter and a half", ğamir issiyyāl "the embers of the acacia tree".

\subsubsection{Influence of 1}

Like $r, I$ may also be involved in inhibiting elision of the short vowel. Examples are (preserved vowels underlined) tākil imn álbahạ "you eat from the sea", yinzil išwayyih "it comes down a little", 'ayyil ișgayyir "a young child", biyhawmil alhamāyil "he brings the animals to be slaughtered (to a wedding party)".

Examples of 'expanded' or 'greater' bukara-vowels preceding $l$ in sandhi (where the vowel is not a cluster-resolving anaptyctic as described in 2.3.2.) are ('greater' bukara-vowels underlined): šuguul iğdūdna "of our fore-

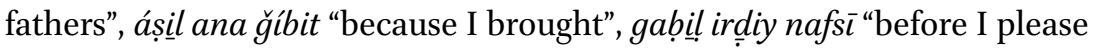
myself", gabịl il Uțmāniyyinn "before the Ottomans".

2.2.2.2.1. The high vowel preceding $\mathrm{l}$ in *ibil and *rağil

One of the forms for she-camels is bil, and with article álbil (BWA, not recorded in MzA). rağil for "man" was only recorded once in BWA (and

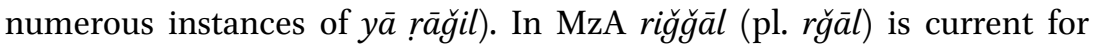
"man".

2.2.2.3. Articulatory delay in the realization of $\mathrm{n}$

The realization of $n$ is often delayed, which leads to an intrusive vowel being realized with an I.P.A. value around [ə], e.g. (here indicated in superscript) fōg ${ }^{\supset} n a$ "above us", ittafag ${ }^{2} n a$ "we agreed", axád ${ }^{2} n i$ " "we took", yib nih "he builds it". An instance in sandhi is in e.g. (vowel underlined) bithuttuh $f i$ ssi in iw bitxudduh "you put it in the goat skin and you churn it".

\subsubsection{Articulatory delay of 'ayn following geminates}

In isolated instances an articulatory delay of 'ayn following a geminate can be heard, e.g. binhutț ${ }^{\circ}$ 'alēh "we put on it". 


\subsection{Anaptyxis}

In terms of rule order, the anaptyxis rule follows the rules for elision and stress.

The rules are:

1.) In the anaptyxis rule speech pause has the same function as a consonant.

2.) Clusters of three or four consonants are usually resolved by inserting an anaptyctic vowel preceding the last two consonants of the cluster. The rule for anaptyxis is:

$\mathrm{I}=$ anapyctic vowel

$$
\varnothing>\mathrm{I} /\left(\mathrm{C}_{\mathrm{a}}\right) \mathrm{C}_{\mathrm{b}-}-\mathrm{C}_{\mathrm{c}} \mathrm{C}_{\mathrm{d}}
$$

The rule holds for word-medial clusters, as well as sandhi clusters.

\subsubsection{Word-medial anaptyxis}

Like in other dialect groups in Sinai, word-medial clusters (in bold print below) resulting from high vowel elision are resolved by inserting an anaptyctic vowel (underlined below) preceding the last two consonants of the cluster, e.g.

$$
\begin{array}{lll}
\text { yurbut }+u w & >\text { *yurbtuw } & >\text { yúrubtuw "they tie" } \\
\text { tuḍ } r u b+u h & >\text { *tuḍrbuh } & >\text { túdurbuh "she hits him". }
\end{array}
$$

\subsubsection{Anaptyxis in sandhi}

2.3.2.1. Anaptyxis in clusters resulting from 'colliding' morphological base forms

Examples of sandhi clusters of four consonants caused by the collision of morphological base forms, which are resolved by insertion of an anaptyctic preceding the last two consonants: (the first cluster is four consonants, the second is three (both in bold print, anaptyctics are underlined):

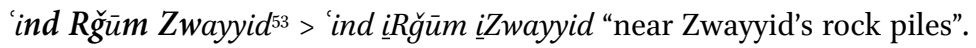

\footnotetext{
53 rğūm, sg. riğm is a pile of small rocks alongside a path or track to indicate its direction, see Bailey 1991:438 and Holes and Abu Athera 2009:246 (glossary).
} 
Another example of (word-medial) collision of base forms is:

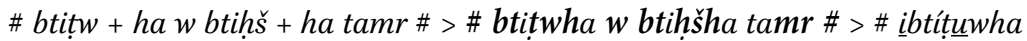
$w$ ibtíhišsha tamir \# "you fold it (sg. fem.) and stuff it (sg. fem.) with dates" (both verb forms are apocopated imperfects).

\subsubsection{Anaptyxis in \#CC and CC\#}

When speech pause directly precedes or follows CC, the resulting cluster \#CC or CC\# is resolved, e.g. (clusters are bold, anaptyctics are underlined):

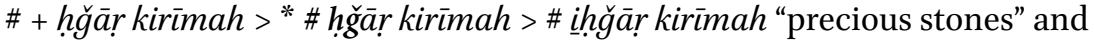
Maṣr + \# > Mașr \# > Mașir \# "Egypt (the mainland), Cairo".

\subsubsection{Consonant clusters resulting from I-elision in sandhi, with} subsequent anaptyxis

Some examples of clusters in sandhi after I-elision, eliminated by anaptyxis (intermediate forms with clusters are marked with *):

(base forms, high vowel eligible for elision underlined) w btilhig iddagìg w bta'ağnuh > (after elision of high vowel, clusters in bold print)

* $w$ btilhg iddagìg $w$ bta'ağnuh > (after stress and anaptyxis, anaptyctics underlined: surface forms) w íbtílihg iddagig w íbtáa ănuh "and you take the dough and knead it".

Another example is:

(base forms, high vowel eligible for elision underlined)

yimsîk alfanāğül >

(after elision of high vowel, cluster in bold print)

* yimsk alfanāăg̈l >

(after stress and anaptyxis, anaptyctic underlined: surface forms) yímisk alfanāğ

\subsubsection{Resyllabication of word-medial CVCCICV, and of CVCCIC VC}

\section{sequences in sandhi}

The resyllabication of a word-medial sequence CVCCICV > CVCICCV (e.g. yikitbuw) is compulsary, while resyllabication of a sandhi sequence CVCCIC VC > CVCICC VC (e.g. yimisk alfanāğ

\subsubsection{Exceptions to the anaptyxis rule}

\subsubsection{Unresolved consonant clusters}

Like in group I, not all clusters are eliminated. Especially clusters of which the first consonant is a semi-vowel, a nasal or a liquid followed by a voice- 
less second consonant, ${ }^{44}$ e.g.: ilhalb hāda "this milking", alGlā iyyih "location where water from šarafat ilGā' flows into Wādiy Fērānn", 'amaltha "I did it (sg. fem.)", álgrab "the water skins", tušǵúlk \#55 "it (sg. fem.) occupies you", tanshi "forget her!", fihimt lay kēh? "do you understand what I mean?" and (with semi vowels) mīyt kïluh "a hundred kilometres", ištaraytha "I bought it (sg. fem.)". But in some cases, also when the second consonant is voiced, the cluster is left intact, as in ǧildha "her skin" (where $d$ is homorganic with $l$ ) and yinzluw "they go down".

Examples of other sandhi clusters left intact are: int 'ärif "you know", yā bint! \# "hey, girl!" and 'ind Biniy Wāṣil "with the Baniy Wāṣil" (see 2.3.3.3.2.) and gult lèhuw "I said to them".

When assimilation between the first and second consonant takes place, the cluster will remain intact as well, e.g. (axadtha >) axattha "I took it (sg. fem.)".

2.3.3.2. The role of sonority of consonants involved in unresolved clusters See remarks in De Jong 2000:125-126.

\subsubsection{Some special cases with regard to anaptyxis}

\subsection{Consonant clusters with initial geminates}

When the first two consonants of a three-consonant cluster form a geminate, this geminate is usually (partially) reduced, e.g. (word-medial) biddna "we want, need", nmiddhin "we stretch them (fem.) out", thutțha "you place it (fem.)" ithammṣ ilbunn "you roast the coffeebeans", tğammr išwayyih "it (sg. fem.) becomes glowing embers a little". Sandhi examples are: nxušš $f i$ "we

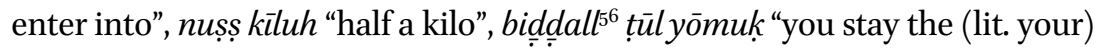
whole day", sinn \# "tooth" and hatț \# "he placed", nšidd \# "we pull tight".

When a cluster contains a geminate and two other consonants, it is resolved, e.g. bass igrūš "but sharks", țābb iNwēbic "going to (sg. masc.) Nwēbi", sitt išhūr "six months".

\subsection{Preposition ind $+C$}

The suffixed preposition 'ind takes vowel-initial allomorphs of the pronominal suffixes, e.g. 'indaha "with her", induk "with you (sg. masc.)", "indik "with you (sg. fem.)", 'induhuw "with them (pl. masc.)", 'indihin "with them (pl. fem.)", 'indukuw "with you (pl. masc.)", 'indikin "with you (pl. fem.)" and "indina "with us".

\footnotetext{
54 For similar phonetic conditioning, see De Jong 2000:123-128.

55 Velarization spread through the whole word, colouring the vowels $i$ (of measure 4 , as in yišğil) to $u$.

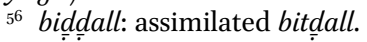


Clusters in sandhi are left unresolved, e.g. (underlined): 'ind Biniy Wāṣil "with the Baniy Wāșil", la 'ind șulbuk "(submerged in water) up to your waist", 'ind ǧidditī rḥa "my grandmother has a hand mill".

2.3.3.3.3. The 2nd p. sg. masc. and fem. pronominal suffixes in consonant clusters

Like in group II of the north (the dialects of Samā'nah and 'Agāylah), the pronominal suffixes of the 2nd p. sg. masc. and fem. $-k$ and $-k$ (resp.), are vowelless when preceded by one consonant. This may be concluded from stress assignment, but it is difficult to decide whether an anptyctic is present or not; especially with a voiceless consonant preceding and a vowel following $k$ (in sandhi), there may be a vowelless anaptyctic, or none at all, as in e.g. illiy yațla min dimmitk i itnī yyāh "whatever comes out of your goodness, give it to me". Other examples are: hurmít u $^{u}$ "your wife", awșúf ${ }^{u}$ \# \# "I'll describe to you". nāgít"k "your (sg. masc.) she-camel",

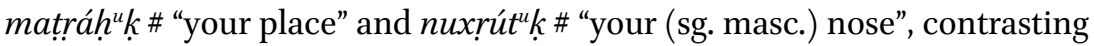
with nuxrít'k \# "your (sg. fem.) nose".

When assimilation takes place, an anaptyctic is absent, e.g. sarákk $(<s a r a ́ g+k)$ "he robbed you".

When more than one consonant directly precede, the personal pronominal suffixes take allomorphs $-u k$ (for sg. masc.) and -ik (for sg. fem.) e.g. xalluk gāid "remain seated", 'induk "with you", șadruk "your chest", nafsuk "yourself", 'umruk "your age" and (doubling of $n$ in he preposition min) minnuk "from you". The latter example is actually a strong indication that we are dealing with a vowel-initial allomorph; $n$ of the preposition min is only doubled in such cases (i.e. the suffixed form is not ${ }^{*} \min k$ or ${ }^{*} \min ^{u} k$ ).

\subsubsection{Phonetic quality of the anaptyctic}

\subsubsection{Phonetic quality of word-medial anaptyctics}

The phonetic quality of the word-medial anaptyctic vowel is a lax and centralized [1], towards [ə], in front environments and a lax and centralized $[\mathrm{v}]$, towards a moderately rounded [ə], in back environments. ${ }^{57}$

\subsection{Phonetic quality of word-medial anaptyxis in clusters form "colliding"} base forms

Examples of the phonetic quality of word-medial anaptyxis in clusters form "colliding" base forms are:

\footnotetext{
57 This is the same as what was described for group I in De Jong 2000:128.
} 
irm + ha $>$ *irmha $>$ irimha "throw it (sg. fem.)"

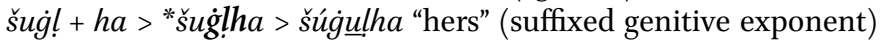

\subsection{Phonetic quality of anaptyctics in clusters after I-elision}

The phonetic quality of the anaptyctic resolving a cluster resulting from high vowel elision is the same as (or near to) that of the vowel from whose elision the cluster resulted (anaptyctic vowels underlined).

Example with $i$ :

$$
\begin{array}{ccc}
\text { base form elision } & \text { anaptyxis } \\
\text { yisrig }+u w & >^{*} \text { yisriguw } & >^{*} \text { yisrguw } \\
>\text { yísírguw "they steal" }
\end{array}
$$

Example with $u$ :

$$
\text { tuktul+uw >*tuktuluw >*tuktluw >túkutluw "you (pl. masc.) hit" }
$$

2.3.4.1.3. Anaptyctics in clusters resulting from elision of $\mathrm{i}$ from $T$

Anaptyctics eliminating clusters resulting from high vowel elision from -it (the fem. morpheme in construct state) are phonetically conditioned by the phonetic value of surrounding consonants: $i$ in neutral environments and $u$ in velarized environments (anaptyctic vowels are underlined) (examples of $i$ ): xíligtuh "his ugly mug", 'ilibtuh "his packet" and (examples of $u$ ) húrumtuh "his wife" and šug $\underline{u}$ ltt "mine (suffixed genitive exponent)".

\subsubsection{Phonetic quality of anaptyctics in sandhi}

\subsection{Phonetic quality of word-initial anaptyctics in sandhi}

Word-initial anaptyctics tend to have a phonetic value of around a lax and centralized [1].

Examples of word-initial anaptyctics (underlined): \# ítkūn írfayy'ih "it (sg. fem.) will be thin", zilìt iṣgayyir "a young goat or gazelle", \# iymūṣ íšwayyih "it becomes a little soft/moist", ahád ịmn ịş̧ābuk \# "one of your friends".

Imperatives of the verbs axád "take" and akál "eat" are kul, \# uḳlíy, \#

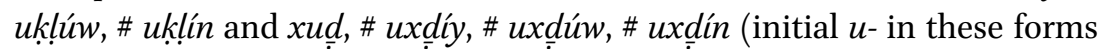
is an anaptyctic resolving a cluster \# CC).

\subsection{Phonetic quality of word-final anaptyctics}

Anaptyctics resolving word-final clusters have a phonetic quality near I.P.A. [v] in labial and/or velarized environments.

Examples are: baduw \# "Bedouin", hiluw \# "sweet, beautiful", daluw \# "pail”, šugul \# "of (genitive exponent)", țhur \# "circumcision”, humur "red (pl. com.)”, zurug "black (pl. com.; lit. "blue”)”, iduk \# “your (sg. masc.) 
hand", bētuk \# "your (sg. masc.) house", min gabul \# ( min gabil \#) "before (adv.)", ğamur \# ( ğamir \#) "live embers", rubu \# ( rubi \#) "quarter”.

Anaptyctics in neutral environments will be near (centralized) [1], e.g. și ib \# "difficult", mitir \# "metre", giriš \# "shark", Șadir \# "Ṛās Șadr", wagit \# "time", xašim \# "long nose".

\subsubsection{Stressed original anaptyctics}

Instances of stressed original anaptyctics - like those found in intitial positions in other dialects such as írkab or árḳab "knees", íhna "here" etc. ${ }^{8}$ - were not recorded in MzA and BWA..$^{9}$

In BWA stress in the preposition / with a consonant-initial suffix will be on the vowel of the suffix, e.g.; \# ilhá or \# ilhi" "to her", \# ilkúw "to you (pl. masc.)", \# ilkín "to you (pl. fem.)", etc. Forms in MzA are lēha or lēhi', lēḳuw and lèkin.

In MzA and BWA the preposition $m(i)^{c}$ followed by a vowel-initial suffix will be stressed on the vowel of that suffix, e.g. m'úh, m'úk, m'ík and also $m i$ (contrast with forms in some dialects of group VII of the type im'uh, where the original anaptyctic is stressed). However, forms of the type ma'áh, ma'úk and ma'ík ( ma'kiy) were also recorded in BWA (through direct elicitation).

\subsection{Elision of Short Vowels}

High short vowels $i$ and $u$ are dropped in open syllables. Short $a$ in comparable positions is not dropped (with an exception, see below), which makes BWA and MzA 'différentiels' in Cantineau's terminology. ${ }^{60}$ The high-vowel elision rule comes before the stress rule in terms of rule ordering. The rule is:

$$
\begin{aligned}
& \mathrm{I}>\varnothing /(\mathrm{V}) \mathrm{C}_{\mathrm{a}}\left(\mathrm{C}_{\mathrm{b}}\right)_{-} \mathrm{C}_{\mathrm{c}} \mathrm{V} \\
& \mathrm{I}=\text { short high vowel } i \text { or } u \\
& \mathrm{C}=\text { any consonant }
\end{aligned}
$$

The morphophonemic elision rules are compulsary.

\footnotetext{
${ }^{8}$ Such forms are, for instance, found in groups II and III of the north (see De Jong 2000:270-271 and 355, and in group VII in the south (see Chapter I, 1.1.6.).

59 The regular reflex for the pl. pattern ${ }^{*} \mathrm{CICaC}$ in MzA and BWA is CCaC. Examples are: gmam "Morray eels", rkab "knees" (MzA), etc, cf. 3.1.9.2.

6o See Cantineau 1936:49.
} 


\subsubsection{Morphophonemic I-elision}

The rule for elision of unstressed I in open syllable preceded by only one consonant:

$$
\mathrm{I}>\varnothing / \mathrm{VC}_{\mathrm{a}}-\mathrm{C}_{\mathrm{b}} \mathrm{V}
$$

Examples are (high vowel eligible for elision in bold print): nizil $+u w>$ *niziluw > nizluw "they descended", simi + at > "simiat > sim'at "she heard", kubur + at > *kuburat > kubrat "she grew older", tāxid + in > *tāxidin > tāxdin "you (pl. fem.) take", mištigil (= underlying |mištağil $\mid)+$ ah > *mištagilih > mištáglih "working (sg. fem.)" and tahariț + uw > *taharituw > táhartuw "you (pl. masc.) plough".

The rule for elision of unstressed I in open syllable preceded by two consonants is:

$$
\mathrm{I}>\varnothing / \mathrm{VC}_{\mathrm{a}} \mathrm{C}_{\mathrm{b}}-\mathrm{C}_{\mathrm{c}} \mathrm{V}
$$

Examples of immediate elimination of a cluster resulting from high vowel elision: tufruš $+i y>$ *tufrušiy > túfuršiy "you (sg. fem.) spread out", yiktib + in > *yiktibin > yíkitbin "they (pl. fem.) write".

When an unstressed high vowel follows a geminate, it is dropped and the geminate is reduced. The rule is:

$$
\mathrm{VC}_{\mathrm{a}} \mathrm{C}_{\mathrm{a}}=\text { geminate }
$$

$$
\mathrm{I}>\varnothing / \mathrm{VC}_{\mathrm{a}} \mathrm{C}_{\mathrm{a}}-\mathrm{C}_{\mathrm{b}} \mathrm{V}
$$

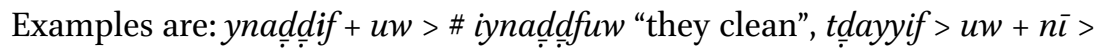

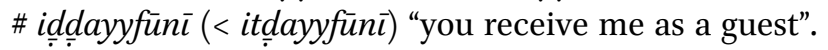

\subsubsection{I-elision in sandhi}

I-elision in sandhi may take place like morphophonemic elisions described above, but such sandhi-elisions are optional, examples are (high vowels eligible for elision are in bold print): btílhig iddagig > btillhg iddagìg > \# ibtilihg iddagig "you take the dough", byimsik issi'n > byimsk issi' > \# ibyimisk issi in \# "he takes the goatskin (used for churning butter)".

\subsubsection{Cyclic anaptyxis rule in sandhi}

The optional I-elision rule in sandhi may be applied after the execution of the anaptyxis rule, e.g. (the cluster is underlined and in bold print, the anaptyctics are in bold print and the high vowel eligible for sandhi-elision is underlined): 
1) twakkil + 'yälk $>$ twakkil $y a \bar{a} l k>t w a k k i l$ i $y a ̈ l k>$ (including word-initial and word-final anaptyxis) \# itwakkl ìyāluk \# "you feed your children".

In this first example the cluster $l y$ is resolved, after which the high vowel preceding it lands in open syllable (thus becoming eligible for elision) and is dropped.

The rule for anaptyxis may also be re-applied after execution of the rule for anaptyxis, ${ }^{61}$ as in the example:

2) nílbis + ğlüdni' > nílbis ğglūdni > nilbis i iğlūdni > nílbs iğlūdni > nílibs iğlūdni' "we put on our diving suits (lit. our skins)".

In this second example the cluster sggl is resolved, after which the high vowel preceding it lands in open syllable (thus becoming eligible for elision) and is dropped, creating a new cluster $l b s$, which is then eliminated by insertion of another anaptyctic vowel.

\subsubsection{Exceptions to the I-elision rule}

When $\mathrm{C}_{\mathrm{a}}$ and $\mathrm{C}_{\mathrm{b}}$ in $\mathrm{C}_{\mathrm{a}} \mathrm{C}_{\mathrm{a}} \mathrm{IC}_{\mathrm{b}}$ are phonetically close or identical, I (underlined in the examples below) is not dropped, and the geminate may be reduced. Examples are: ǧidditī "my grandmother", thálliluh "you analyze it (sg. masc.)".

\subsection{Assimilation}

Three types of contact assimilations can be identified: regressive (partial or total), progressive (partial or total) and reciprocal (total) assimilation (instances of contact assimilation involving the spread of velarization are treated in 1.1.7.).

Apart from contact assimilations of $l$ of the article $i l$ - or $a l$ - to 'sunletters', $l$ is also sometimes - this is by no means regular-assimilated to following ğ or $k$, as in iğğibneh "the cheese". alxayt b áğğ lab "the line with the hooks (used for fishing)" and also ikkis "the bag".

${ }^{61}$ The example in De Jong 2000:134-135 only illustrates the application of the I-elision rule after the execution of the anaptyxis rule (like the first example here). The second example here clearly illustrates re-application and cyclicity of the I-elision rule. 
Instances of regressive total assimilation are:

\begin{tabular}{|c|c|c|}
\hline$n+r$ & $>r r$ & birraǧǧid "we pile" \\
\hline$t+\check{s}$ & $>t s ̌$ & ššlliy “you carry” \\
\hline$t+z$ & $>z z$ & $z z \bar{\imath} d$ "it (sg. fem.) increases" \\
\hline$t+d$ & $>d d$ & ddīr "you turn (fem.)" \\
\hline$\underline{d}+t$ & $>t t$ & axatt "I took" \\
\hline $\bar{t}+\check{\mathrm{s}}$ & $>\check{s} \check{s}$ & ššidd "you pull" \\
\hline
\end{tabular}

Instances of regressive partial assimilation are:

\begin{tabular}{|c|c|c|}
\hline$t+z$ & $>d z$ & $d z i d$ "it (sg. fem.) increases" \\
\hline$t+\check{g}$ & $>d \check{g}$ & $d \check{g} \bar{l} b$ "you bring" \\
\hline$b+n$ & $>m n$ & mnadbahuh "we slaughter him" \\
\hline+ & $>\eta g$ & maygad "fireplace" \\
\hline
\end{tabular}

progressive total:

Initial $h$ - of pronominal suffixes often totally assimilates to preceding voiceless consonants, e.g.

$$
\begin{aligned}
& \text { aǵlabiyyit }+ \text { hin } \quad>\text { a } \\
& \text { ğimā'at + huw > ğimā'áttuw "their group of people" } \\
& \text { tuṭbux }+ \text { ha > tuṭbúxxa "you cook it (sg. fem.)" } \\
& \text { naftah + ha > naftáh̆ha "we open it (sg. fem.)" }
\end{aligned}
$$

Other instances of progressive total assimilation are:

$$
\text { zagrat + tiy > zagrátțiy “you (sg. fem.) ululated" }
$$

Instances of reciprocal total assimilations are:

$$
\begin{array}{ll}
\text { baraǧği }+ \text { ha } & >\text { barağíhhe "I return it (sg. fem.)" } \\
\text { mablag }+ \text { hin } & >\text { mibláxxin "their (fem.) price" }
\end{array}
$$

In a number of instances the mutual influence of hissing sounds has resulted in a metathesis. An example in both dialects is siğih (or sižih)

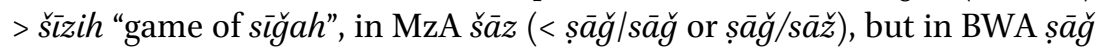
"iron baking sheet". Additional examples in MzA are šizn (< siğn or sižn) "prison", mšazzil (> saǧğil or sažžil) "recorder" and našz (> nasğ or naš̌) "weaving", but in BWA siğn and tasğı̆l "recording".

Another example of the mutual influence of hissing sounds is MzA is šamš (> šams) "sun", but BWA šams, and in both dialects šağar "trees" is current. 


\section{MoRPHOLOGY}

\subsection{Nominal Morphology}

\subsubsection{Raising of a}

3.1.1.1. Raising of a in $C_{1} a C_{2} i C_{3}(a h)$

Raising of $a$ in the nominal pattern $\mathrm{C}_{1} \mathrm{aC}_{2} \mathrm{IC}_{3}(\mathrm{ah})$ occurs regularly, but is optional. Such raising is not inhibited by phonetic factors.

Examples are: šidìd "intense, strong", kițīr "many, much", kibīr "large, old", gilì "fat, thick", 'ifı́g, 'irìs "groom", xifíf "light". But also forms without raising have been recorded: katīir, kabìr, 'afı̈g, xafîf, etc.

\subsubsection{Raising of a in open syllable preceding stressed í}

For instances of raising of $a$ in the $i$-type perfect (with underlying pattern $\mathrm{CaCiC}$ ) of verbs, see 3.2.1.1. below.

\subsubsection{Raising of a in $\mathrm{CaCCiC}(-a h)$}

Raising of $a$ in $\mathrm{CaCC} \overline{\mathrm{i}} \mathrm{C}(-\mathrm{ah})$ was not recorded, e.g. batțix "water melon", xamsin "fifty", sab ìn "seventy" and a verbal noun tağlīb "throwing out (of a fishing line)".

\subsubsection{Raising of a in $\mathrm{CaCC} \overline{\mathrm{C}} \mathrm{C}$}

Raising of a in $\mathrm{CaCC} \overline{\mathrm{C}}(+)$ is regular. Examples are: riğǧāl "man", șiyyād "fisherman", siyyāl $l^{62}$ "acacia tree", kiššā $f$ "search light", bitțāriyyih "flashlight", zirgā "blue (sg. fem.)", șif̣ā "yellow (sg. fem.)", himrā "red (sg. fem.)", gir 'a "bald (sg. fem.)", mirrrāt "times", mi nàt (hāàgih) "the meaning (of sth)", Wādiy Wirdān "Wadi Wardān".

3.1.1.5. Raising of a in ...CaCāC...

When not followed by $l$ or $r$ and not preceded by ', unstressed $a$ preceding $\bar{a}$ may be raised to $i$ or $u$. Examples are: ( $i$ in) gizāyiz "bottles", mišāyix "sheikhs", digāyig "minutes", dināgìy "small boats" (BWA), gibāyil "tribes", tikātrih "doctors" and (u in) Șuwālḥih "name of tribe Șawālhah", buwāṣiy

\footnotetext{
${ }^{62}$ sayyāl is likely to be a folk etymology for sayāl. The connotation must be with 'a tree growing by a sēl ("flood, watercourse")'.

${ }^{63}$ The sg. dingiy is a loan from English dingy, which must have come through one of the Egyptian dialects where the reflex for * ${ }^{\circ}$ is $g$ and where the English [dz] was replaced by $[\mathrm{g}]$. Compare this to an opposite development of $g$ in Egyptian ginēh (a loan from English guinea), where $[\mathrm{g}]$ was replaced by [dz] by speakers of ğ $\mathrm{im}$-speaking dialects, who pronounce $\breve{g}(i) n \bar{e} h$. Other such examples are sīgạrah "cigarette" and grāam "gram",

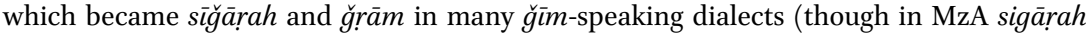
is current).
} 
"a type of fish (pl. form)", min muwālìd Daháb "born in Dahab" and also (as an exception) durāhim "money" (but see remark below) and verb forms nisāh "he forgot him" and ligāh "he found him".

Such raising is however optional, since there are also many instances in which it is absent, e.g. masākinhuw "their dwellings", 'Azāzmih "name of a tribe (living partly in Sinai and partly in the Negev)", Hamādah "name of a tribe", zamān "in the past", gabāyil "tribes" and also verb forms ytawāğad "it (sg. masc.) exists" and yta álağ "he receives medical treatment".

When $a$ is followed by $l$ or $r$ or preceded by ' or $\mathrm{X}$, this type of raising is much less regular, e.g.: talätih "three", Tarāāin "name of a tribe", wara $\bar{a}^{u} k$ "behind you", marākib "boats" and (with 'preceding) 'asāsāthuw "their origins". 'ažānib "foreigners", 'așābi "fingers" and 'aḍ̂âfirk "your (sg. fem.) nails". Examples in which X precedes $a$ are: 'ašàn "because", hawāliy "about, approximately", harārah "heat", xalāṣ "that's it!", ġazāl "gazelle" and hawä $\bar{a}^{u}$ "your desire".

3.1.1.6. Raising of a in ...CaCá...

$a$ in open syllable preceding stressed $a$ is often-but only optionally soraised to I in neutral environments, ${ }^{64}$ e.g.: sináh "year", šiǧár "trees", libán "milk", ǧimál "camel”, fị̂a "free time", Diháb "name of the town Dahab", a gahawah-form šihár "month" and verb forms ligát "she found", kitáb "he wrote".

Raising towards [u] is heard in the examples: $m \bar{a}$ m'uk duwá "medicine", wurág "paper" (though more regularly warág).

Such raising is (usually) absent when 'or X precedes, e.g.: (')ahád "anyone" and verb forms (')akál "he ate" and (')axád "he took" and (with X preceding) hațáb "firewood", ganám "small cattle", 'adád "number", 'arág "sweat" and xalág "He created", but also gitás "he dived" and mā miuk xubár "you have no clue/idea".

\subsubsection{Raising of a in open syllable preceding stressed $A$}

Both types of a-raising described in 3.1.1.5. and 3.1.1.6. can be combined in one rule (see also De Jong 2000:147):

$$
\begin{array}{ll}
\mathrm{C}_{\mathrm{a}} \neq * \text { or } \mathrm{X} & \mathrm{a}>\mathrm{I} / \mathrm{C}_{\mathrm{a}}-\mathrm{C}_{\mathrm{b}} \mathrm{A} \\
\mathrm{C}_{\mathrm{b}} \neq l . & \mathrm{A}=\text { stressed } a \text { or } \bar{a} \\
& \mathrm{I}=\text { high short vowel } i \text { or } u
\end{array}
$$

\footnotetext{
${ }^{64}$ See the rule in De Jong 2000:145 is: a $>\mathrm{I} / \mathrm{C}_{\mathrm{a}}-\mathrm{C}_{\mathrm{b}}$ á, where $C_{\mathrm{a}} \neq{ }^{*)}$ or $\mathrm{X}$ and $\mathrm{C}_{\mathrm{b}} \neq l$.
} 
And like in group I, stress of A does not have to be primary for such raising to take place. Instances where stress on A is secondary are, e.g.: ğibābil "mountains", min muwālìd Diháb "born in Dahab", mikānī "my place" and ánwikal "it was eaten", háwğisat "she improvised song", ánnixal "the palmtrees" and also in forms with final raised reflexes of $-\bar{a}\left({ }^{\prime}\right)$, such as áddiwi "the medicine" and ássimi "the sky".

\subsubsection{Raising of a in $\mathrm{CaCu} C(a h)$}

Like in the pattern $\mathrm{CaCi}^{-} \mathrm{C}(\mathrm{ah}), a$ is often raised to I in the pattern $\mathrm{CaCu} \mathrm{C}(\mathrm{ah})$, but instances of absence of such raising were also recorded. Examples are lugūnih "a child with keen intelligence", ${ }_{5}$ yuhüd "Jews", Su'üdiyyih Sa'ūdiyyih "Saudi Arabia", gu'ūd "young male camel", ġumūs "food dip", xurūf "lamb", but also ğanūb "south", 'ağüz "old woman", 'arūs 'urūs "bridegroom", ša ūr šu úur "emperor (fish species)" and also hakūmah "government". 66

Also when (') precedes, such raising often takes place: (')ubüy "my father", (')uxūh "his brother" and also in verb forms (')ugüm "I get up, (')ušüf"I see"..$^{67}$

\subsubsection{Raising of $\mathrm{a}$ in open syllable preceding stressed $\mathrm{u}$}

Like raising of $a$ in open syllable preceding stressed $i, a$ in similar positions preceding stressed $u$ is also raised, e.g.: kubúr "he grew", gulúd "he grew fat".

3.1.1.10. a-raising rules combined

If we combine the different possibilities of raising in one rule, this rule is:

$$
\begin{aligned}
& \mathrm{a}>\mathrm{I} / \mathrm{C} \_\mathrm{CI}(\mathrm{C}) \\
& \mathrm{I}=\operatorname{short~high~vowel~} u \text { if } \hat{\mathrm{I}}=\dot{u} \text { or } \bar{u}, i \text { if } \hat{\mathrm{I}}=\boldsymbol{i} \text { or } \bar{\imath} \\
& \mathrm{C}=\text { any consonant }
\end{aligned}
$$

Notice that the rule is more general than the (second) one formulated in De Jong 2000:15o, since we do not need to make a provision here for the first $\mathrm{C}$ not being hamzah.

\footnotetext{
${ }_{65}$ The word was used in reference to a child, who is recognized at an early age to have a keen intelligence, and is therefore raised to become a häwiy "snake charmer". It is related to the root $l-q-n$ "learn; have keen intelligence" and must mean "endowed with intelligence" and/or "(to be) taught through instruction".

${ }^{66}$ See also fn 18, Chapter Two in De Jong 2000:149.

${ }^{67}$ Such raising following' is not current in group I (see De Jong 2000:147-149).
} 


\subsubsection{Reflexes of ${ }^{*} \mathrm{C}_{1} a \mathrm{C}_{2} \mathrm{C}_{3}(a h)$}

Examples of reflexes of ${ }^{*} \mathrm{C}_{1} \mathrm{aC}_{2} \mathrm{C}_{3}(\mathrm{ah})$ are: $b a d w$ "Bedouin (pl.)", ğady (BWA) "kid goat", tahát tihát "under", fahám "coal", šikl "shape", șahán șihán "dish", kalb "dog".

Also: wiğh "face", wiḥdih "one (fem.)", nahyih "direction", și $b \sim s ̧ a b$ (the latter perhaps a K-form; notice the absence of a gahawah-vowel), șadr "chest", wakl "food" and ǧidd "grandfather".

\subsubsection{Reflexes of ${ }^{*} \mathrm{CaCiC}(a h)$}

Examples of reflexes of * $\mathrm{CaCiC}(\mathrm{ah})$ are: kilmih "word", širkih "company", kitf "shoulder".

\subsubsection{Reflexes of $\mathrm{C}_{1} u \mathrm{C}_{2} \mathrm{C}_{3}(a h)$}

Examples of reflexes of ${ }^{*} \mathrm{C}_{1} \mathrm{uC}_{2} \mathrm{C}_{3}(\mathrm{ah})$ are: bunn "coffee beans", rizz ( ruzz in MzA) "rice", kull "all; every", aṃm "mother" ( uṃm in BWA), uxt "sister".

Also: Ğim ih "male given name", sinnih "usage" (BWA), middih "period", hinnih "they (pl. fem.)", zibdih "butter".

Forms with sufficient backing show $u$, as in šuggah "fishing net" (MzA), xutwah "step", nugțah "police checkpoint", gumsih "food dip", rukbah "knee" (BWA) (but rikbih (MzA)), hurmah "woman".

\subsubsection{Absence of I in open syllables preceding stress}

Like in all dialects of Sinai, a high vowel $i$ or $u$ in open initial syllables of the type $\mathrm{CIC}(\mathrm{V})$ preceding stress (on V) is dropped, resulting in initial CC clusters. Examples are: ǧlūd "skins", 'yūn̄̄ "my eyes", xšěšāt "little huts", Hmēed "male given name", byèt ša ár "little tent", blād "land", ǧbāl "mountains", snìn "years", glayyil "little; few", g!̣̆l "few (pl.)" and štiy "winter". Examples with stressed short vowels are: gmam "Morray eels", rkab "knees" (MzA).

Exceptions to such elisions are (loans from MSA) šu'ūn iğtimāìyyih "social affairs", nizām "system". ${ }^{68}$ Another exception is șayd furūsiyyih "hunting on horseback" (in BWA), where the influence of $r$ may have prevented elision of $u$ in furūsiyyih (if it is not a loan from MSA altogether). For other 'surface' forms with initial sequences of the type CiCā... or

\footnotetext{
${ }^{68}$ Notice also $z$ here instead of more regularly expected emphatic interdental $\underline{d}$.
} 
CuCā..., $\mathrm{CiCi}_{1} \ldots$ or $\mathrm{CuCī} \ldots$ and $\mathrm{CuCū \ldots or} \mathrm{CiCu} \ldots$ see 3.1.1.7.-3.1.1.10. above.

Also in verb forms a short high vowel in open unstressed syllable is not found, e.g. ygūl "he says", tšll "you carry", tnām "you sleep", nhutțt "we place", tšiddiy "you (sg. fem.) pull tight", ygōtruw "they go". Notice, however, that in the verb "come" the vowel of the first syllable is not dropped, e.g. tiğı́y "you come”, yiğı́y "he comes" (contrast with forms tğiy and y̌ğiy heard in group I). ${ }^{69}$

\subsubsection{Diminutive patterns}

A number of diminutive forms were recorded in MzA and BWA. Apart from the usual forms such as glayyil "few", gsayyir "short", rfayyi "thin", șgayyir "small; young", kwayyis "good" and šwayyih "a bit", etc., other recorded examples are: sraybih "small group (of people)", byēt ša ár "little tent", xšěšāt "little huts", bnayyih "little girl", wlèd "little boy" and also a very regular (i.e. in Sinai) hrayyim "women".

The hypochoristic - $\bar{a} n$ suffix, which was recorded in some of the dialects of group I (especially dialects in the east like AhA), was not heard in MzA or BWA.

\subsubsection{Pattern $a C_{1} C_{2} a C_{3}$}

The pattern used for colours and physical (and sometimes mental) defects is $\mathrm{aC}_{1} \mathrm{C}_{2} \mathrm{aC}_{3}$ and $\mathrm{aC}_{1} \mathrm{aC}_{2} \mathrm{aC}_{3}$ (stressed on the first syllable) where $\mathrm{C}_{1}=\mathrm{X}$. Examples are: abyad "white", azrag (euphemistically; the word aswad is avoided) "black; dark coloured", ašhab "light coloured, pale" (and with $\mathrm{C}_{1}=\mathrm{X}$ ) áhamar "red", áxạ̣ar "green", áhawal "cross-eyed", áhabal "stupid", áama "blind" and áxaraṣ "mute", á arağ "limping".

The sg. fem. forms have a CaCCā pattern, with a final $-\bar{a}$ that has remained long and which is often in pause followed by an unreleased glottal stop, e.g. be $\underline{d} \bar{a} \bar{a}^{\prime}, h a m r \vec{a}$. There is an added $a$ following $\mathrm{C}_{2}$ when it is $\mathrm{X}$ and final $\bar{a}$ is raised (to -íy) when $\mathrm{C}_{3}$ is neutral, e.g. 'arǧı́y and šaḥabíy.

Most pl. com. forms have a $\mathrm{C}_{1} \mathrm{uC}_{2} \mathrm{C}_{3}$ pattern, e.g. zurg, sumr, $x u \underline{d}$ r, humr and $h u b l$, but some forms that lack velarization were recorded with a $\mathrm{C}_{1} \mathrm{iC}_{2} \mathrm{C}_{3}$ pattern, e.g. 'irğ, šị̣b. Plural forms for "black" and "white" are sūd $\left(\mathrm{C}_{2}=w \bar{a} w\right)$ and $b \bar{c} \underline{d}\left(\mathrm{C}_{2}=y \bar{a}\right)$.

\footnotetext{
${ }^{69}$ See De Jong 2000:203-204.
} 
3.1.8. The elative patterns $a C_{1} C_{2} a C_{3} a C_{1} a C_{2} C_{3}$ and $a C_{1} C_{2} a$

The elative pattern is $\mathrm{aC}_{1} \mathrm{C}_{2} \mathrm{aC}_{3}$, e.g. aktar "more/most", akbar "bigger/biggest; older/oldest", ashal "easier/easiest", aș 'ab "more difficult/most difficult".

In MzA forms ahla "sweeter/sweetest; better/best" and ahsan "better/ best" were recorded several times without a gahawah-vowel (similarly aǵlabiyyih "majority"), but a gahawah-vowel was heard in axatar "more dangerous/most dangerous" (though also axțar). agalaḍ "thicker" and also ahala in BWA.

Elatives of geminate roots have a pattern $\mathrm{aC}_{1} \mathrm{aC}_{2} \mathrm{C}_{3}$ (where $\mathrm{C}_{2}=\mathrm{C}_{3}$ ), e.g. aga!l "less/least" and ahamm "more important/most important".

\subsubsection{Initial a}

\subsubsection{The article and the relative pronoun}

The article may be $a l$ - or il-; al-is mainly used when the following nominal has $\mathrm{Ca}$ as its initial sequence, but this is in no way regularly so. When the article is stressed, however, the article tends to be ál- when (underlying) $\mathrm{Ca}$ or $\mathrm{CCaC}$ follows, and il- when other sequences follow. Examples with (underlying) Ca following are: álbahar "the sea", álğimal "the camel", áddiwi" "the medicine", ássimi "the sky", asșșạan "the plate", but (when preceding sequences other than Ca) ilihșiy "the rocks" and ilif ' $i$ " the viper", iššti "the winter", but ișșibiy "the boy" (underlying form is |șabiy|). With CCaC following: árrkab "the knees", ánnxar "the noses", áll'af "the bait (pl.)", áššnat "the suitcases".

When $\bar{\imath}$ or $i y$ precedes the article $a l$-, it is dropped, as in, e.g.f-ațiür "in aț-Ṭū" and f-awwalha w hatta f-āxirha "in its (sg. fem.) beginning and even in its (sg. fem.) end".

In some cases in BWA the possessive suffix $-\bar{\imath}$ was not dropped against initial $a$ - of a following verb, but an intrusive (voiced?) $h$ was inserted instead, e.g. widd $\bar{\imath}$ - $h$-aṣalliy "I want / am going to pray", widdī-h-anām "I want to (go to) sleep". This not only occurred with following initial $a$-, but also in directly elicited instances like widdī-h-udrub "I want to hit", widdīh-ugūm "I want to get up", widdi-h-ōgaf "I want to stop", widdi-h-äkil "I want to eat" and also with initial $i$-following, as in widdì-h-išrl "I want to carry".

The relative pronoun is illiy, e.g. illiy 'āyiz luh kìlu, $w$ illiy 'āyiz luh nuṣs kilu "(there are) those who want a kilo and others who want half a kilo".

'Specifying' ha- was heard used only in adverbial halhīn (often halhinit in MzA) "now". 


\subsubsection{Other instances of initial a}

Another instance of initial $a$ is amm "mother" (in MzA, in BWA ummm), "we" is ihna, "sister" is uxt.

Like in group I, plural forms reflecting older ${ }^{*} \mathrm{CICaC}$ have a $\mathrm{CCaC}$ pattern, e.g. gmam "Morray eels", rkab "knees" (MzA), rxaṣ "licences", 'nab "grapes" (BWA), hgan "injections", šnat "suitcases", l'af "bait (pl.)", although the pl. for (')ibrih is (')abár "needles".

\subsubsection{The feminine morpheme $(T)$ in genitive construction}

\subsubsection{T in genitive construction preceded by a in open syllable}

The feminine morpheme - $a h \sim-i h$ in construct state becomes - at when aC directly precedes. Examples of aCT + suffix: máratuh "his wife", sánatuh "his year", xašabát $t^{u} k$ "your piece of wood".

In the case of $\mathrm{CaCaCT}+\mathrm{v}(\mathrm{C})$ sequences in $\mathrm{MzA}$, a special provision needs to be made for $a$-elision in the rule for short vowel elision, which in terms of rule ordering precedes the rule for $\mathrm{T}$. This should explain why $\mathrm{T}$ becomes - $i t$ in such cases: since $a$ has been dropped from CaCaCTv (resulting in $\mathrm{CaCCTv}$ ), $\mathrm{T}$ is no longer directly preceded by aC, but by $\mathrm{CC}$. Therefore $\mathrm{T}>\mathrm{it}$, resulting in a sequence CaCCitv. Since the rule for short vowel elision has already been executed (and this rule is not cyclic!), such $\mathrm{CaC}$ Citv sequences will not be resyllabified to (after applying stress and anaptyxis rules) become CáCiCtv, but the sequence is stressed and appears on the surface as CáCCitv. Examples of such sequences are rágbituh "his neck", xášbituh "his piece of wood".

Verbal forms of the $3 \mathrm{rd} \mathrm{p}$. sg. fem. $a$-type perfect + vowel are resyllabified analogous to the suffixed nominals; the rule was generalized to cover all (including verbal) sequences: $\mathrm{CaCaCat}+\mathrm{v}>\mathrm{CaCCitv}$, e.g. $($ farašat $+u h>$ ) fáršituh "she spread it out" and katabat + uh >) kátbituh "she wrote it".

The advantage of fitting the extra provision with regard to elision of $a$ into the ordering of rules is that the T-rule, which holds in almost all Sinai dialects, does not have to be customized to fit the situation in MzA.

Also, an advantage of this rule-generalization is that no separate rule is needed for the sudden appearance of $-i t$ in the case of the 3 rd p. sg. fem. of $a$-type perfects when vowel-initial suffixes are appended..$^{70}$

$7^{70}$ From the point of view of historical development, such a rule would be highly unlikely, since the verbal ending is -at under all other circumstances, see verbal morphology in 3.2 . 


\subsubsection{The rule for $T$ not directly preceded by $a C$ or $\bar{v}$}

When not preceded by aC, the fem. morpheme - $a$ h becomes -it (or - $t$ when a long vowel $\overline{\mathrm{v}}$ directly precedes, see 3.1.10.4.) in construct state.

The $i$ of the ending -it may then be subject to the rule for high vowel elision, after which often an anaptyctic vowel is inserted (underlined in following examples), e.g.: 'ílibtuh "his packet", 'ilbít"k "your packet", fátrit $a r b a^{\prime} \sin$ (with sandhi elision and anaptyxis >) fátirt arba ísnīn "a period of four years", nāgtuh "his she-camel", nāgituk "your (sg. masc.) she-camel". In strongly velarized environments T may be realized as -ut, as in nuxrút $t^{u} k$ "your (sg. masc.) nose", contrasting with nuxrít'k "your (sg. fem.) nose".

\subsubsection{T preceded by the gahawah-vowel a}

Forms in which a gahawah-vowel $a$ is in open syllable directly preceding $\mathrm{T}$ are treated the same way as forms in which such a preceding $a$ is 'historical'. Almost paradoxically so, the forms gahwit̄̃ and gáhwitu (and similar forms like laḥmitì and láhmituh) show that the gahawah-syndrome has created fully-fledged syllables in these nominals, for if the gahawahvowel $a$ would have been a mere anaptyctic vowel (i.e. more like in verb forms, cf. 2.1.2.4.), one might have expected forms like gahawtī and gáhawtu. The fact that the gahawah-vowel $a$ is dropped from (intermediate) forms like *gahawati and *gahawatuh thus illustrates that we are dealing with a full short vowel $a$ (produced by the gahawah-syndrome), since only $\mathrm{CaCaCT}+\mathrm{v}$ sequences are affected by the special provision made in the short vowel elision rule (as described above).

\subsubsection{T following $\bar{a}$}

T preceded by $\bar{a}$ yields -āh, e.g. hamātuh "his mother-in-law",

In one instance *ma'nā (spelled in Arabic with 'alif maqșūrah: معنى) was interpreted as T-final (as occurs more often in other dialects as well): mināt ilkilmih "the meaning of the word".

3.1.10.5. Nominal ending -it in construction vs. verbal $3 r d p$. sg. perf. ending -at The high vowel $i$ of the nominal ending -it is dropped when it is in open unstressed syllable, e.g. nāgtuh "his she-camel", gatțāytuh "its (sg. masc.) cover".

The low vowel $a$ in verbal forms of the 3 rd p. sg. perf. is not dropped, e.g. šăfatuh "she saw him" and lāgatuh "she found him", kāwanatuh "she fought him". 


\subsubsection{Genitive marker}

The genitive marker is $\check{s} u \dot{g} !$, but in more isolated areas (away from the coast) hagg is more current in MzA. In BWA šuğl is the current form, although hagg may also be heard. Though not as regularly as šugl, the K-form $b t \bar{a}{ }^{c}$ may also be heard. The form taba' was heard only once in $\mathrm{MzA}$.

The paradigms for suffixed $\check{s} u \dot{g} !(a h)$ and $h a g g(a h)$ are as follows:

\begin{tabular}{|c|c|c|c|c|}
\hline e.g. & ilbēt + & & il'ilbih + & \\
\hline & & pl. & sg. & pl. \\
\hline $\begin{array}{l}\text { 3. masc. } \\
\text { fem. }\end{array}$ & $\begin{array}{l}\text { šug்luh } \\
\text { šúg்ulha }\end{array}$ & $\begin{array}{l}\text { šúġulhuw } \\
\text { šúg்uḷin }\end{array}$ & $\begin{array}{l}\text { šúg்ultuh } \\
\text { šúglítha }\end{array}$ & $\begin{array}{l}\text { šuglíthuw } \\
\text { šuǵlíthin }\end{array}$ \\
\hline 2. masc. & šuğtuk & šúg்ulkuw & šug̣lít ${ }^{u} k$ & šug̣lítkuw \\
\hline fem. & šug̣tik & šúg்uḷin & šuglı́t'k & šug̣lítkin \\
\hline com. & śuğ̣̣ & šúg்ulna & šugulttī & šuǵlítna \\
\hline
\end{tabular}

Pl. forms used for humans are šug̣tīn and šug̣lāt: e.g. iliwlād šuğtīn ilmádrasih "the boys of the school" and ilbanāt šug̣tàt ilmádrasih "the girls of the school". Also for smaller or numbers the pl. fem. is used: ittalātah ǧinēhāt dillih šug $\underline{g}^{a} t^{u} k$ "these three pounds are yours".

$\begin{array}{lllll}\text { e.g. } & \text { ilbēt }+ & & \text { il'ilbih }+ & \\ & \text { sg. } & \text { pl. } & \text { sg. } & \text { pl. } \\ \text { 3. masc. } & \text { hagguh } & \text { hagghuw } & \text { haggtuh } & \text { haggithuw } \\ \text { fem. } & \text { haggha } & \text { hagghin } & \text { haggitha } & \text { haggithin } \\ \text { 2. masc. } & \text { hagguk } & \text { haggkuw } & \text { haggit }{ }^{\prime} \text { ha } & \text { haggitkuw } \\ \text { fem. } & \text { haggik } & \text { haggkin } & \text { haggit'k } & \text { haggítkin } \\ \text { 1. com. } & \text { haggi } & \text { haggna } & \text { haggti } & \text { haggítna }\end{array}$

Pl. forms for humans are haggīn and haggàt: e.g. iliwlād haggìn ilmádrasih and ilbanāt haggāt ilmádrasih. Like in the case of šug̣tāt, the pl. fem. haggāt is often used for smaller numbers: ițtalātah ğinēhāt dillih haggāt ${ }^{u}$.

A preference for the construct state instead of indirect annexation could not be concluded from the available data.

\subsubsection{Personal pronominals}

3.1.12.1. Independent pronominals

In MzA the following independent pronominals are used: 


\begin{tabular}{|c|c|c|c|c|}
\hline & & & negated: & \\
\hline & sg. & pl. & sg. & pl. \\
\hline 3. masc. & $h \bar{u}$ & huwwa $(h)$ & $m \bar{u} h \bar{u}^{*}$ & mūhuwwa $(h)$ \\
\hline fem. & $h \bar{\imath}$ & hinnah & $m \bar{\imath} h \bar{\imath}^{*}$ & mïhinnih \\
\hline 2. masc. & $\operatorname{int}(a h)$ & intuw & $\operatorname{mint}(a h)$ & mintuw \\
\hline fem. & intiy & intin & mintiy & mintin \\
\hline 1. com. & ana & ị̣na & $m \bar{a} n \bar{\imath}^{*}$ & míhna \\
\hline
\end{tabular}

Direct elicitation yielded the following negated forms in BWA: $m \bar{a} h \bar{u}^{*}$, māh $\imath^{*}$, mintah, mintì, mānı $\imath^{*}$, māhumma, māhinnah, mintuw, mintin, mihna.

* In these forms stress is on the vowel of the first syllable.

For a likely development of the pl. masc. form huwwa - in which reinterpretation of morpheme boundaries must have played an important rolesee 3.1.12.2. in the preceding chapter and also De Jong 2000:163.

3.1.12.2. Pronominal suffixes

In MzA the following pronominal suffixes are used:

\begin{tabular}{|c|c|c|}
\hline & $\begin{array}{l}\text { sg. } \\
(\mathrm{C}) \mathrm{C}-u(h)^{*_{1}}, \overline{\mathrm{v}}-(h)\end{array}$ & $\begin{array}{l}\text { pl. } \\
-h u w^{*}\end{array}$ \\
\hline fem. & $-h a$ & -hin \\
\hline 2. masc. & C- ${ }^{u} k$, CC- $u k, \bar{v}^{-}{ }^{u} k^{* 2}$ & $-k u w$ \\
\hline fem. & $\mathrm{C}-{ }^{i} k, \mathrm{CC}-i k, \overline{\mathrm{v}}-k^{* 2}$ & $-k i n$ \\
\hline 1. com. & $\begin{array}{l}\text { (C)C- } \bar{\imath}, \overline{\mathrm{v}}-y \text { (poss.) } \\
-n \bar{\imath}(\mathrm{obj} .)^{*_{3}}\end{array}$ & $-n a$ \\
\hline
\end{tabular}

For allomorphs used with the preposition 'ind, see below 3.1.16.

${ }^{* 1}$ Notice the $-u(h)$ suffix for the 3 rd p. sg. masc., instead of $-a h /-i h$ which we find in group I.

${ }^{*_{2}}$ The superscript vowel ${ }^{u}$ serves to indicate a considerable degree of velarization (accompanied by lip rounding); it is not to be interpreted as a vowel, which may be concluded from stress placement and (lack of) short high vowel elisions in forms like hurmit " $k$ "your (sg. masc.) wife" and $n \bar{a} i^{\prime} t^{u} k$ "your (sg. masc.) she-camel". Contrast this with forms followed by 2nd p. sg. fem. suffixes: 'ilbit'k "your (sg. fem.) pack", nāgit'k.

When ${ }^{u} k$ is suffixed to $\overline{\mathrm{v}}$, the long vowel colours strongly towards $[\mathrm{u}]$ before $k$ is released, e.g.: 'ile $e^{u} k$ "on you", $f i^{u} k$ "in you", gif $\bar{a}^{u} k$ "your neck". Contrast these with forms followed by and p. sg. fem. suffixes: 'ilēk, fik and gifäk.

When lip-rounding is already present, there appears to be a slight difference in the pronunciation of $u b \bar{u} k$. "your (sg. masc.) father" and $u b \bar{u} k$ 
"your (sg. fem.) father"; the long vowel $\bar{u}$ preceding $k$ is more tense than $\bar{u}$ preceding $k .^{7^{1}}$

*3 Like most in Bedouin dialects of Sinai ${ }^{2}$ we find stressed suffixes $-\bar{\imath}$ and $-n \bar{\imath}$ for the 1 st p. sg. com. Unstressed $-i$ and $-n i$ also occur.

*4 Parallel to independent pronominals, the 3 rd p. pl. masc. suffix is formed with $-w$, rather than with $-m$ (although a few instances with final $-m$ were recorded).

For the development of second person pronominal suffixes $-k$ and $-k$ see NOTE in 3.1.12.2. in the preceding chapter.

\subsubsection{Demonstratives}

3.1.13.1. Near and far deixis

Near deixis*2:

$\begin{array}{lll} & \text { sg. } & \text { pl. } \\ \text { masc. } & (h \bar{a}) \underline{d} a h^{*_{1}} & (h \bar{a}) \text { dilll }(i h)^{*_{2}} \\ \text { fem. } & (h \bar{a}) \underline{d} i y & (h \bar{a}) \underline{d i l l i h} / \underline{\operatorname{dill}} \bar{e} l(i h)^{*_{2}}\end{array}$

Forms without initial $h \bar{a}$ - are much more regular than in group I.

Far deixis*2:

$\begin{array}{lll} & \text { sg. } & \text { pl. } \\ \text { masc. } & (h \bar{a}) \underline{d} \bar{a} k(a h) & (h \bar{a}) \underline{d a ́} \text { ll } a k(a h)^{*_{2}} \\ \text { fem. } & (h \bar{a}) \underline{d} \bar{k} k(a h) & \end{array}$

*1 In pause often $\underline{d i h}$ or $\underline{d i}$.

$*_{2}$ The forms listed here with initial $h \bar{a}$ are current in BWA, but occur only sporadically in MzA. Another pl. form recorded in MzA was hädēlah. For presence / absence of velarization in these forms, see remarks ${ }^{*_{2}}$ and ${ }^{*_{4}}$ in chapter I, 3.1.13.1.

To express "there he/she is (lit.: has come)" or "there they are (masc./fem.) (lit. have come)" a prefix $h \bar{e}$ - precedes the personal pronominals, as in hèhū ği !' "there he is!", hēhì ğàt "there she is!", hēhuwwa ğuw "there they (masc.) are!", hēhinnah ğin "there they (fem.) are!".

${ }^{71}$ These remarks are based on mere impressions, not on precise machine-aided measurements.

$7^{2}$ See De Jong (2000:3.1.12.2. of ch. I-III) and (2003:163). 
3.1.13.2. Specifying ha-

Specifying $h a-$, which is especially current in group I dialects (see De Jong 2000:172-173), was heard only in halhin ( halhinit in MzA) "now" and once in halyōm "today" (the latter only recorded in BWA).

\subsubsection{Interrogatives}

min is used independently for "who?", but another possibility to enquire after someone's identity is $\min$ (with a short vowel) in combination with a pron. suff., as in $\min$ hu-h-intih? "who are you?".

"What?" is ē̌s? ( much less often $\bar{e} h)$; "why?" is lēh? (both in sentenceinitial, as well as sentence-final position); "where?" is wēn?; "when?" is mitēh? or wagtēš?; "how?" is kēf?; "how much?" is gaddēš?; kam + sg.? is "how many?", yāt bèt "which house?" and yāt bint "which girl?".

\subsubsection{Adverbs}

3.1.15.1. Adverbs: "there", "over there (far away)", "here", "thus", "now", "still", "afterwards, after that"

"Here" is nihāa(') or nihāniy* in MzA and hniy in BWA ( $f$ h hāda is also used),

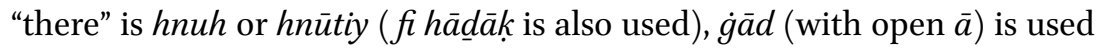
for "over there (far away)". "Thus" is kídiy or often kidiyyih (and less often kidiyyāniy), "now" is halhīn ( halhīnit in MzA), "still" is l issā' and "afterwards, after that" is ba'adèn.

* When min precedes niha, , one syllable is haplologically dropped, e.g. imšin mi-nhä or mi-nhāniy "go away (pl. fem.) from here!".

\subsubsection{2. "maybe"}

For "maybe" no forms based on the root $x-w-f$ (for undesirable possibilities, e.g. $x \bar{a} f a ! l l a h$, see De Jong 2000:177) or $k$-w-d (for positive possibilities, kūd see ibid. 178) were recorded, but only yimkin.

3.1.15.3. bilhayl "very, extremely"

b ilhayl "very, extremely" is often used in BWA to qualify an adjective, e.g.

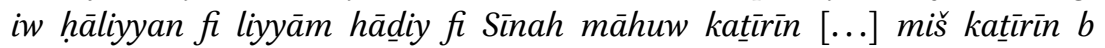
ilhayl... "And now, these days, they are not many in Sinai [...] They are not very many...". Another example is [...] iw zayy kidiy $b \bar{\imath} d \bar{e}^{u} k$, bitgatți ...alkáakih $w$ tuf ưukha $w$ bithutț 'älēha lèha... issamin iwlāha hilwih $b$ ilhayl..." and like this with your hands you break the cookie to pieces and crumble it. And you add, put ghee on it, and (then) it is extremely tasty...”. 
3.1.15.4. bišwēš "slowly, carefully"

The adverb bišwēš was not recorded in MzA or BWA. Instead, a construction like šwayyih šwayyih is current.

3.1.15.5. min xawf "lest"

min $x a w f$ in the sense of "lest" (see De Jong 2000:179) was not recorded.

\subsubsection{Prepositions + pers. pronominal suffixes}

In BWA the pron. suffix for the 2nd p. sg. fem. $-k$ co-occurs with $-k i y$, e.g. fik fikiy "in you (sg. fem)". and also lik lkiy "to you (sg. fem.)".

In direct elicitation, the -ak suffix was also recorded for the 2 nd p. sg. masc., though in spontaneous texts only - ${ }^{u} k$ or $-u k$ was heard.

Suffixed prepositions in MzA are:

\begin{tabular}{|c|c|c|c|c|c|}
\hline$l i+{ }^{*}{ }_{1}$ & & cala $+{ }^{*}$ & & $m(i)^{c}+*_{3}$ & \\
\hline luh & lēhuw & 'ilēh & 'ilēhuw & muh & miḥḥuw \\
\hline lèha & lèhin & 'ilēha & 'ilēhin & miḥha & miḥḥin \\
\hline luk & $\overline{l e}^{u} k \underline{u w}$ & 'ile $\bar{e}^{u} k$ & 'ile $e^{u} k \underline{u w}$ & miuk & mikuw \\
\hline lik & lèkin & 'ilēk & 'ilēkin & mik & mikin \\
\hline $\operatorname{lay}(y)^{*_{4}}$ & lēna & 'alay $(y)^{* 4}$ & 'ilēna & $m^{i} \bar{\imath}$ & mina \\
\hline
\end{tabular}

$*_{1}$ The paradigm is mixed; forms like $l \bar{e} u k$ and $l \bar{e} h$ are much less frequently used than luk and luh. A similar paradigm is used for $b+$. The suffixed proposition $l+$ may be enclitically suffixed, e.g. ğâluk "he came to you", gultilhi' "I said to her" (notice that the form is not lèha), ahsál-luk "it is best for you" (assimilated ahsan + luk), but this is not always the case, as may be concluded from stress in e.g. gălat luh "she said to him", tfakkir luh "you look at him" (i.e. these examples are not stressed gālát-luh and tfakkir-luh, which would be the forms in case of enclitic suffixing).

In BWA the short base instead of the forms with $\bar{e}$ is more current: Iha, lhuw, lhin, lkuw, lkin and lna.

*2 Raising of short $a$ to $i$ in open syllables preceding stressed $\bar{e}$ (as indicated here) is optional, but very regular.

BWA forms are the same, though raising of $a$ in these positions is much less regular than in MzA.

As independent prepositions both 'ala and ' $a$ (not only when preceding the article) are current.

*3 The short vowel $i$ is dropped when vowel-initial suffixes follow (including $-u k$ and $-i k)$, but stressed when consonant-initial suffixes are involved and ' and $h$ reciprocally assimilate to become $h h$.

* For a remark on lay and 'aláy, see 1.2.4.1. 
In BWA forms are the same.

\begin{tabular}{|c|c|c|c|c|c|}
\hline$f i+$ & & $f o ̄ g+{ }^{* 1}$ & & $\min +^{* 2}$ & \\
\hline fih & fihuw & föguh & fōghuw & minnuh & minhuw \\
\hline fiha & fihin & fōgha & fōghin & minha & minhin \\
\hline$f \iota^{u} k$ & fi $u k u w$ & $f \bar{o} g^{u} k$ & fōgkuw & minnuk & minḳuw \\
\hline$f i k$ & fikin & $f \bar{o} g^{i} k$ & fögkin & minnik & minkin \\
\hline $\operatorname{fay}(y)^{* 3}$ & fina & fōgi & fögna & $\operatorname{minn} \bar{\imath}$ & minna \\
\hline
\end{tabular}

*1 Alternatively one can say min hardī "above me" min ḥarduk "above you (sg. masc.)", etc. ${ }^{73}$

$*_{2}$ Notice here that the $n$ is doubled preceding the short vowels in the suffixes $-u k$ and-ik, which indicates that the vowels of these allomorphs are not merely anaptyctic vowels.

*3 fay must have developed in analogy to lay and 'aláy, see remark above.

The preposition min is usually stressed in the compounds mín-tahat "from below", min-kidiy "from this".

\begin{tabular}{|c|c|c|c|}
\hline $\begin{array}{l}\text { wara }+ \\
\text { warāh }\end{array}$ & warāhuw & $\begin{array}{l}\text { 'ind + } \\
\text { 'induh }\end{array}$ & "induhuw" \\
\hline warāha & warāhin & indaha*2 & "indihin" \\
\hline$w a r \bar{a}^{u} k$ & warāḳuw & 'induk & 'indukuw" \\
\hline wara $k^{*_{1}}$ & warākin $^{*_{1}}$ & indik & indikin" \\
\hline warāāy & warāna & 'indī & 'indina*2 \\
\hline
\end{tabular}

$*_{1}$ In the forms for the 2 nd p. fem. the velarization created by the preceding $r$ is gradually lost during articulation of the following $\bar{a}$. Thus an opposition between $w a r \bar{a}^{u} k$ and warāk is maintained.

$*_{2}$ Notice that the allomorphs used with this preposition are all vowel-initial.

\subsubsection{Numerals and counted plurals}

3.1.17.1. Cardinal numbers 1-10

Independent cardinal numbers are (forms that precede counted nouns

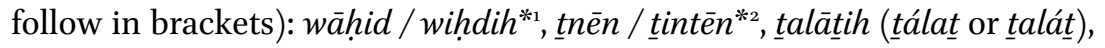
arba'ah (arba'), xamsih (xams), sittih (sitt), sab'ih (sab'), tamānyih (táman or tamán), tis ih (tis'), 'ašarah ('ašaṛ).

73 Šuqayr (1916:341), however, lists hard in the meaning of bi ğănib "beside". 
* wăhid and wihdih may follow the counted noun as adjectives for extra emphasis, e.g. walad wāhid "one boy" and bint wiḥdih "one girl".

*2 tnên and tintèn may follow the counted dual form of the noun as adjectives for extra emphasis, e.g. waladēn ițnèn "two boys" and ìdèy ițtintēn or idèy tintēnhin "my two hands".

Some plural forms of nouns are counted with proclitic $t$ - (a remnant of the fem. morpheme in construct state), e.g. 'ašar t-infär "ten people", talat t-iyyam "three days".

\subsubsection{Ordinal numbers 1-10}

Only three ordinals were recorded: awwil, țāniy, țâlit.

3.1.17.3. Numerals: 11 and up

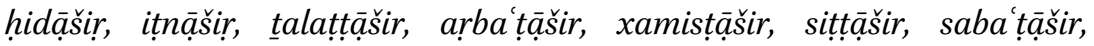

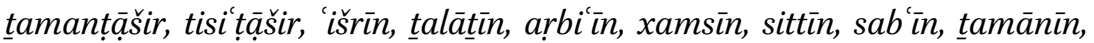
tis'in, miyyih, miyytēn, tultmiyyih, rubimizyih, xumsmiyyih, suttmiyyih, subimiyyih, tuminmiyyih, tusimiyyih, alf, alfēen, talat t-äläf, xamis t-älāf,

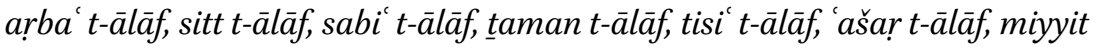
alf, miyytēn alf, malyūn.

\subsubsection{The dual}

Suffixing -èn or -ayn to the sg. form of a noun forms the dual, e.g. šaharayn "two months", sbü'ayn "two weeks", nō'ayn "two kinds" and -èn (in neutral environments) 'arabiyytēn "two cars", miyytēn "two hundred", rikibtēn "two knees", sanatēn "two years", bintēen "two girls".

Older forms of the dual are used in expressions for body parts, e.g. riğlēy "my (two) legs" and riǧlē"k "my (two) hands" and ìdèy "my (two) hands" and $\bar{\imath} d \bar{e}^{u} k$ "your (two) hands".

\subsection{Verbal Morphology}

3.2.1. Regular verbs

\subsubsection{Regular verbs perfect}

In all vowel-types of the perfect and imperfect, the end and 3rd p. pl. masc. ending is $-u w$, the and and $3 \mathrm{rd} \mathrm{p}$. pl. fem. ending is -in (including the $a$ - and $i$ - types of the tertiae infirmae) and the ending of the 3 rd p. sg. fem. is -at (except in the verb 'come', see below) ${ }^{74}$

${ }^{74}$ These are differences with group I dialects (see De Jong 2000: several paragraphs under 3.2. in chapter I. 
Perfects of measure 1 verbs come in three types: $\mathrm{C}_{1} \mathrm{aC}_{2} \mathrm{aC}_{3}, \mathrm{C}_{1} \mathrm{iC}_{2} \mathrm{iC}_{3}$ and $\mathrm{C}_{1} \mathrm{uC}_{2} \mathrm{uC}_{3}$. The paradigms are:

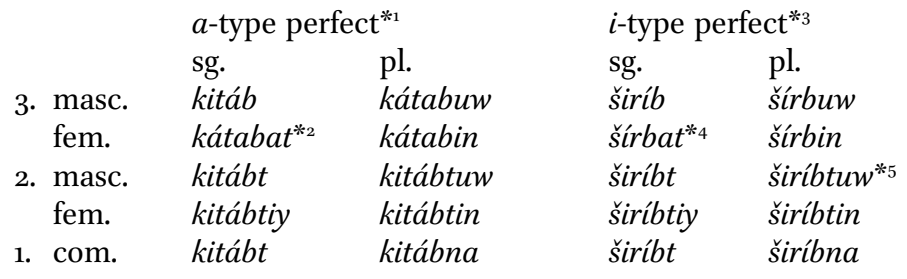

*1 Notice that $a$ (in the first syllable) is raised to $i$ in pre-stress syllables. In a labial environment raising of unstressed $a$ in the first syllable tends to be towards $u$, as in wugáft "I stopped" and wugáftin "you (pl. fem.) stopped", but wágafat "she stopped" and wágafin "they (pl. fem.) stopped". *2 When suffixed with a vowel-initial suffix forms are: kátbitu or kátabatu "she wrote it (sg. masc.)". The latter form may be due to influence from one of the neighbouring dialects (such as TAN), where the form is not resyllabified.

*3 The short high vowel $i$ of the first syllable is actually underlying $|a|$ and is therefore not dropped in open pre-stress syllables. This underlying $|a|$ does not 'reappear' in closed syllables (in contrast with reappearing $|a|$ in some -not all- of the dialects of group I).

*4 Notice that the ending here is -at in the $i$-type perfect, not -it (contrasting with surrounding dialect groups).

*5 'Almost' širíbtum: one of my informants had a tendency to almost close his lips (approximating I.P.A. [m]) when articulating $w$ of pl. verbal endings; one had to look carefully to see that he was not actually producing $m$, because it often sounded as such, also because of the high degree of nasalisation which accompanied his realisation of such final $w \bar{a} w^{75}$ (see also remarks on the situation in HmA (of group VII) and 'LA (group VIII) in 3.2.1.1. of the preceding chapter).

\subsubsection{Regular verbs imperfect}

Like in many dialects in Sinai, the imperfect is characterized by vowel harmony in the verbal prefixes. Another interesting feature is that this vowel harmony has spread through the entire paradigm and that it includes the 1st. p. com. sg. This accounts for the absence of initial $a$ - in

75 This is reminiscent of verbal endings in group II of northern Sinai, see De Jong (2000:3.2. of chapter II). See also remarks in 3.2. above. 
the 1st. p. sg. com. of $i$ - and $u$-type imperfects, which we do find in many other dialect groups (see 3.2.1.2. of the various chapters).

There are three imperfect patterns: $\mathrm{yaC}_{1} \mathrm{C}_{2} \mathrm{CaC}_{3}, \mathrm{yuC}_{1} \mathrm{C}_{2} \mathrm{CuC}_{3}$ and $\mathrm{yiC}_{1} \mathrm{C}_{2} \mathrm{iC}_{3}$, all of which are characterized by vowel harmony in the prefixes:

\begin{tabular}{|c|c|c|c|c|}
\hline & \multicolumn{2}{|c|}{$a$-type imperfect ${ }^{* 1}$} & \multicolumn{2}{|c|}{$i$-type imperfect } \\
\hline & sg. & pl. & sg. & \\
\hline 3. masc. & yášrab & yášrabuw & yiktib & yíkitbuw \\
\hline fem. & tášrab & yášrabin & tiktib & yíkitbin \\
\hline 2. masc. & tášrab & tášrabuw & tiktib & tíkitbuw \\
\hline fem. & tášrabiy & tášsrabin & tíkitbiy & tíkitbin \\
\hline 1. com. & ášṛab & nášrrab & $i k t i b$ & niktib \\
\hline & $u$-type in & rfect $^{*_{2}}$ & & \\
\hline & sg. & pl. & & \\
\hline masc. & yudrub & yúdurbuw & & \\
\hline fem. & tud & yúdurbin & & \\
\hline 2. masc. & tudidrub & túdurbuw & & \\
\hline fem. & túdurbiy & túdurbin & & \\
\hline 1. com. & $u d \underline{d} r u b$ & nuddrub & & \\
\hline
\end{tabular}

$*_{1}$ Notice the lack of vowel harmony in the endings of 2 sg. fem., 2 pl. masc. and fem. and $3 \mathrm{pl}$. masc. and fem. (in contrast with group I). ${ }^{76}$

$*_{2}$ In the $u$-type-provided velarization is lacking - the anaptyctic vowel in the imperfect forms tends to vary, i.e. either $i$ or $u$. One may hear e.g. túgu'duw as well as túgi duw for "you (pl. masc.) sit”, but in velarized forms the anaptyctic $u$ is regular, like in the paradigm listed here.

Measure 1 verbs with $C_{1}=X$ have the following paradigms:

\begin{tabular}{|c|c|c|c|c|}
\hline \multirow{7}{*}{$\begin{array}{l}\text { 3. masc. } \\
\text { fem. } \\
\text { 2. masc. } \\
\text { fem. } \\
\text { 1. com. }\end{array}$} & \multicolumn{2}{|c|}{$i$-type ${ }^{*_{1}}$ imperfect $^{* 2}$} & \multicolumn{2}{|c|}{$a$-type imperfect ${ }^{* 2}$} \\
\hline & sg. & pl. & sg. & pl. \\
\hline & yáharit & yáharțuw & yáarag & yáaraguw \\
\hline & táḥarit & yáharțin & táarag & yáaragin \\
\hline & táḥarit & táḥarțuw & táarag & táaraguw \\
\hline & $\begin{array}{l}\text { táhartíy } \\
\text { áharit }\end{array}$ & táhartin & táaragiy & táaragin \\
\hline & aḥarit & năharit & a arag & ná arag \\
\hline
\end{tabular}

*1 Notice that the lack of vowel harmony in $i$-type imperfects like yaharit implies that, from a historical perspective, the gahawah-rule must be understood to ante-date the rule for vowel harmony (hence forms like e.g. yihrit are not heard in these dialects).

\footnotetext{
${ }^{76}$ See De Jong 2000:190-191.
} 
*2 Perfect harát like katáb (see 3.2.1.1.). My BWA informant articulated sìn instead of $\underline{t} \vec{a}^{\prime}$, e.g. yáharis and yáharsuw, etc.

*3 Perfect 'iríg like simí (see 3.2.1.1.).

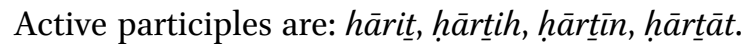

Active participles of the type $\mathrm{C}_{1} \overline{\mathrm{a}} \mathrm{C}_{2} \mathrm{iC}$ (etc.) for the verb iríg, yáarag are not really used, instead for "sweating" one may hear: 'argān, 'argānih, 'argānīn, 'argānāt.

3.2.1.3. Reflexes of older ${ }^{*} \mathrm{C}_{1} a C_{2} u C_{3},{ }^{*} \mathrm{yaC}_{1} \mathrm{C}_{2} u C_{3}$

$u$-type perfect ${ }^{* 1}$

3. masc. kubur kubruw

fem. kubrat ${ }^{*_{2}} \quad$ kubrun $^{*_{3}}$

2. masc. kuburt kuburtuw

fem. kuburtiy kuburtin

1. com. kuburt kuburna

*1 The Classical Arabic 'Eigenschafts' verb-type (which expresses a certain characteristic) $\mathrm{C}_{1} \mathrm{aC}_{2} \mathrm{uC}_{3} \mathrm{a}, \mathrm{yaC}_{1} \mathrm{C}_{2} \mathrm{uC}_{3} \mathrm{u}$ has $\mathrm{C}_{1} \mathrm{uC}_{2} \mathrm{uC}_{3}, \mathrm{yuC}_{1} \mathrm{C}_{2} \mathrm{uC}_{3}$ reflexes (imperfect paradigm like $y u d \underline{d} u b$, see 3.2.1.2.). Notice that, like in reflexes of C.A. ${ }^{*} \mathrm{C}_{1} \mathrm{aC}_{2} \mathrm{iC}_{3}$ a (such as, e.g., širib), the high vowel of the first syllable of the perfect is not dropped in unstressed positions (so not e.g. $k$ kburt for "I grew"). We may conclude therefore that also in the case of $\mathrm{C}_{1} \mathrm{uC}_{2} \mathrm{uC}_{3}$ perfects, the $u$ of the first syllable is actually underlying a (i.e. like $i$ in the first syllable of $\mathrm{C}_{1} \mathrm{iC}_{2} \mathrm{iC}_{3}$ perfects, see ${ }^{* 3}$ in 3.2.1.1.).

Other $u$-type perfects are: tuxunt "I became fat", hì guldat "she became fat", hinnih guldin "they (fem.) became fat", iddinyah suxu $n a t$ "the weather became hot" (for superscript ", see 2.2.2.3.) and innās kutruw "people became many".

$*_{2}$ Notice the ending -at here, cf. remark ${ }^{*} 4$ in 3.2.1.1. above.

$*_{3}$ Notice that the vowel of the ending -in colours with the preceding vowels $(>-$ un $) \cdot{ }^{77}$

3.2.1.4. Regular verbs participles

Active participles are formed with the patterns $\mathrm{C}_{1} \overline{\mathrm{a}} \mathrm{C}_{2} \mathrm{iC}$ (sg. masc.) $\mathrm{C}_{1} \overline{\mathrm{a}} \mathrm{C}_{2} \mathrm{C}_{3} \mathrm{ah} /$-ih (sg. fem.), $\mathrm{C}_{1} \overline{\mathrm{a}} \mathrm{C}_{2} \mathrm{C}_{3} \overline{\mathrm{i}}$ (pl. masc.) $\mathrm{C}_{1} \overline{\mathrm{a}} \mathrm{C}_{2} \mathrm{C}_{3} \bar{a} \mathrm{t}$ (pl. fem.).

77 Similar colouring was noticed in the imperfect form yukburun, recorded in the dialect of the Rmēlāt in the north, see De Jong:2000:191. 
When the sg. fem. participle is suffixed with an object, it is in construct state with this suffix. Examples are: bānīytuh "having built it (sg. masc.)", hì mìhì 'àyiztuh "she does not want/love him".

\subsubsection{Regular verbs imperatives}

Imperatives of regular verbs have a harmonized initial vowel, while endings are like those in the imperfect paradigm, e.g. ásma', ásma iy, ásma'uw, ásma in "listen!", údrub, údurbiy, ụdurbuw, údurbin "hit!" and íktib, íkitbiy, ikitbuw, íkitbin "write!".

\subsubsection{Irregular and other verbs}

3.2.2.1. Verbs $C_{1}=\mathrm{w}$ (primae wāw)

Imperfect paradigms of verbs with $w \bar{a} w$ as $C_{1}$ are:

$\begin{array}{lllll} & \text { i-type* } & & \text { a-type } & \\ & \text { sg. } & \text { pl. } & \text { sg. } & \text { pl. } \\ \text { 3. masc. } & \text { yōrid } & \text { yōrduw } & \text { yōgaf } & \text { yōgafuw } \\ \text { fem. } & \text { tōrid } & \text { yōrdin } & \text { tōgaf } & \text { yōgafin } \\ \text { 2. masc. } & \text { tōrid } & \text { tōrduw } & \text { tōgaf } & \text { tōgafuw } \\ \text { fem. } & \text { tōrdiy } & \text { tōrdin } & \text { tōgafiy } & \text { tōgafin } \\ \text { 1. com. } & \bar{o} \text { rid } & \text { nōrid } & \bar{o} \text { gaf } & \text { nōgaf }\end{array}$

* The $\bar{o}$ in this paradigm reflects older $a$ in the preformatives of $i$-type imperfects as well, as in e.g. *yawrid, and these are presumably older than the forms with harmonized vowels like e.g. yiktib. Diphthongal preformatives were not recorded.

The imperfect of the verb "light, kindle" was recorded as yog gid. The perfects of prima $w \bar{a} w$ verbs are $\mathrm{C}_{1} \mathrm{iC}_{2} \mathrm{iC}_{3}$ or $\mathrm{C}_{1} \mathrm{aC}_{2} \mathrm{aC}_{3}$ (see above). The imperatives are:

$\begin{array}{lllll} & \text { sg. } & \text { pl. } & \text { sg. } & \text { pl. } \\ \text { masc. } & \overline{\text { orid }} & \overline{\text { orduw }} & \overline{\text { ogaf }} & \overline{\text { ogafuw }} \\ \text { fem. } & \overline{\text { ordiy }} & \overline{\text { ordin }} & \overline{\text { ogafiy }} & \overline{\text { ogafin }}\end{array}$

The imperative áw'a was said to occur in that form only (i.e. uninflected for number or gender): "mind your head(s)!" is thus:

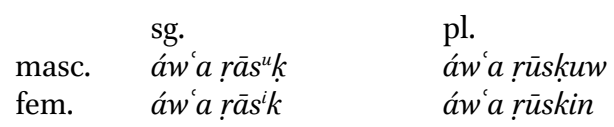

\section{Participles:}

Active participles have a $\mathrm{C}_{1} \overline{\mathrm{a}} \mathrm{C}_{2} \mathrm{iC}_{3}$ pattern, e.g. (with velarized first syllables) wạgif, wāgfih, wāgfin, wạgfăt "standing". 
The passive participle for the root $w$ - $\check{g}$-d was recorded as maw $\check{g} \bar{u} d$ (see 1.2.4.1.).

3.2.2.2. Verbs $C_{1}=\mathrm{y}$ (primae yä)

The only verb recorded with $\mathrm{C}_{1}=y$ is yibis, yēbas "dry (intrans.)".

3.2.2.3. Verbs $C_{1}=$ ' (primae hamzah)

The two verbs "eat" and "take" have similar conjugations. The perfect and imperfect paradigms for "eat" are:

\begin{tabular}{lllll} 
& perfect & & \multicolumn{2}{c}{ imperfect } \\
& sg. & pl. & sg. & pl. \\
3. masc. & akál & ákaluw & yākil & yākluw \\
fem. & ákalat & ákalin & tākil & yāklin \\
2. masc. & akalt & akaltuw & tākil & tākluw \\
fem. & akaltiy & akaltin & tākliy & tāklin \\
1. com. & akalt & akalne & $\bar{a} k i l$ & nākil
\end{tabular}

Active participles are: mākil, māklih, māklīn, māklāt. Past participles are $m \bar{a} x \bar{u} \underline{d},-a h,-\bar{a} t,-\bar{n}$, which is also used meaning "daft".

Imperatives are (these forms are considerably velarized): $x \underline{u} \underline{\underline{d}}, x \underline{\underline{d}} \underline{\mathrm{y}} \mathrm{y}$,

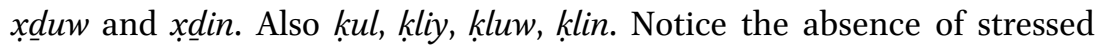
initial $u$-in these forms; an unstressed $u$ - may precede in forms like (here in superscript) " $x$ diy and "ḳluw, but is then-as should be concluded from its lack of stress - a mere anaptyctic vowel.

The verbal nominal is wakl "eating" and the passive verb "be eaten" is ánwikal, yínwikil.

3.2.2.4. Verbs $C_{2}=\mathrm{w}$ or $\mathrm{y}$ (mediae infirmae)

A characteristic of southern dialects is the short base vowel in the 2nd p. sg. masc. imperfect and imperative forms. In MzA and BWA these cooccur with forms with a long base vowel, but in BWA forms with the long base vowel are more current than those with a short vowel.

Perfect and imperfect forms of mediae infirmae are:

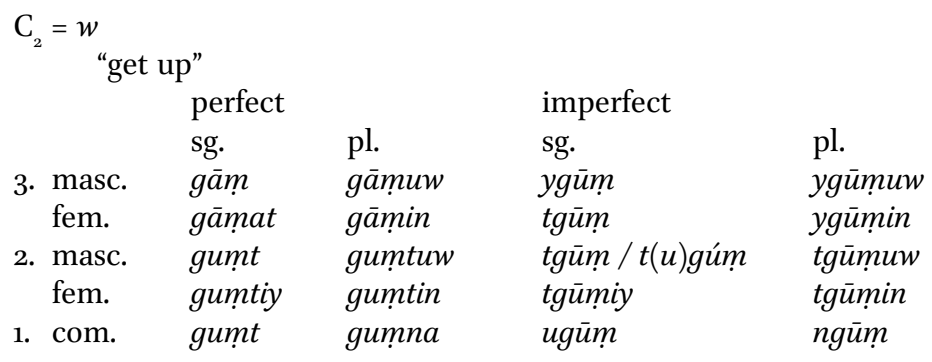


Participles are: gāyim, gāymih, gāymin, gāymāt (no velarization).

The verb $\check{s} \bar{a} f, y s ̌ \bar{u} f$ was recorded in MzA with short vowel $u$, as in šuft, as well as with $i$, as in šift "I saw".

\begin{tabular}{lllll}
\multicolumn{2}{c}{ "sleep" } & & \\
& perfect* & & imperfect & \\
& sg. & pl. & sg. & pl. \\
3. masc. & nām & nāmuw & ynām & ynāmuw \\
fem. & nāmat & nāmin & tnām & ynāmin \\
2. masc. & nimt & nimtuw & tnām / t(a)nám & tnāmuw \\
fem. & nimtiy & nimtin & tnāmiy & tnāmin \\
1. com. & nimt & nimne & anām & nnām
\end{tabular}

Participles: nāyim, nāymih, nāymīn, nāymāt.

$$
\mathrm{C}_{2}=y
$$$$
\text { "carry" }
$$$$
\text { perfect imperfect }
$$

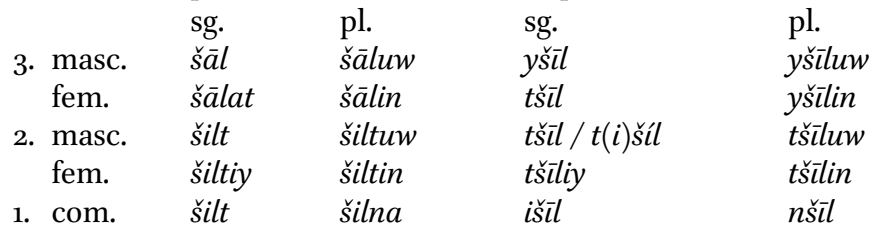

N.B. Where there is variation in group I dialects between the $3^{\mathrm{rd}} \mathrm{p}$. sg. masc. forms biyšll and bišll, both meaning "he carries" (see De Jong 2000:199), in group VI a form like bišll "he carries" (after reduction of the diphthong $i y>i$ ) has become homophonous with the form for the 1st p. sg. com. "I carry".

3.2.2.4.2. Verbs $C_{2}=\mathrm{w}$ or $\mathrm{y}$ (mediae infirmae) imperatives

Like in the imperfect, imperatives of the 2nd p. sg. masc. often have short base vowels and may have a short vowel preceding, as in šil "carry!", ugúm "get up!". Examples are: nām, nāmiy, nāmuw, nāmin, gūm / ugúm, gūmịiy, gūmuww, gūminin.

Imperatives used with the verb ǧăb, yğìb are: hāt, hātiy, hātuw, hātin.

3.2.2.4.3. Verbs $C_{2}=\mathrm{w}$ or y (mediae infirmae) participles

Active participles of measure 1 are formed with the patterns $\mathrm{C}_{1}$ āyiC ${ }_{3}$, $\mathrm{C}_{1}$ āyC $\mathrm{ih}_{3}, \mathrm{C}_{1}$ āyC $\mathrm{C}_{3} \mathrm{in}$ and $\mathrm{C}_{1}$ āyC $\mathrm{C}_{3}$ àt.

A passive partiple is mašy $\bar{u} l$ etc. 


\subsubsection{Verbs $C_{3}=\mathrm{y}$ (tertiae infirmae)}

\subsection{Verbs $C_{3}=\mathrm{y}$ (tertiae infirmae) perfect}

Below two paradigms are listed of perfects of tertiae infirma verbs that are actually mixed; some forms originate from the $a$-type perfect, while other forms in the same paradigm are originally $i$-type forms:

In MzA the following paradigms were elicited:

\begin{tabular}{|c|c|c|c|c|}
\hline & $\begin{array}{l}\text { rget" } \\
i \text {-type } \mathrm{p}\end{array}$ & & $\begin{array}{r}\text { go, walk" } \\
a \text {-type }\end{array}$ & $\operatorname{fect}^{*_{2}}$ \\
\hline & sg. & pl. & sg. & pl. \\
\hline masc. & nisi" & nisyuw ${ }^{* 1}$ & miši" & mišyuw \\
\hline fem. & nisyat $^{* 1}$ & nisyin $^{*_{1}}$ & mišyat & mišyin \\
\hline masc. & nisìt & nisītuw & mišēet & mišētuw \\
\hline fem. & nisītiy & nisītin & mišētiy & mišètin \\
\hline com. & nisìt & nisinna & mišēt & mišēna \\
\hline
\end{tabular}

$*_{1}$ Another informant, however, claimed that forms like ligyuw and ligyin are not MzA. According to him, proper MzA forms are ligúw (< *laguw) (a suffixed example is ligūh) and ligín (<* lagin) (a suffixed example is ligínnuh) and by analogy one would then also expect ligát for the 3 rd p. sg. fem. (< $<$ lagat). The 3rd p. sg. masc. form nisi $\left(<{ }^{*} n a s \bar{a}\right)$-instead of nisíy-must then have crossed over from the $a$-type perfect (compare miši ', see remark below). for the paradigm of the $i$-type elicited in BWA, see below.

$*_{2}$ The verb is listed here as an $a$-type perfect, since mišı oped from *maš $\bar{a}$, and endings in $-\bar{e}+$ clearly belong to the $a$-type (for raising of the $a$ preceding the stressed $\bar{e}$ see 1.2.3.4.3.2.), but the endings of the 3 rd p. pl. and 3 rd p. sg. fem. (i.e. those with $y$ ) are identical with the $i$-type endings. For similar $a$-type forms recorded in the dialect of Biliy of group I in northern Sinai, see De Jong 2000:201. The forms of the $a$-type perfect in BWA are the same as in MzA.

Suffixed forms are, e.g.: nisìtuh "I forgot him" and nisināh "we forgot him", which are quite straight forward $i$-type, but forms like nisäh "he forgot him" and ligāh "he found him" point to the a-type. Similarly: hì nísyituh or násatuh "she forgot him" and ligyituh or (less current) lágatuh "she found him". Other examples (with doubling of $n$ ) in nisitinnuh "you (pl. fem.) forgot him" and nisyinnuh or (alternatively) nisinnuh "they (f.) forgot him" and alternatives like ligyūh / lagūh (after raising ligūh) "they found him".

Imperatives of tertiae $y \vec{a}$ verbs are apocopated in the sg. masc., e.g. the verbs yirmiy "throw" and yimšiy: 


$\begin{array}{lll} & \text { sg. } & \text { pl. } \\ \text { masc. } & \text { irm* / imš } & \text { irmuw / imšuw } \\ \text { fem. } & \text { ímiy / imšì } & \text { irmin / imšin }\end{array}$

* When followed by a pause or a consonant, an anaptyctic vowel appears, e.g. (underlined): írim \#! "throw!" and írimha "throw it (fem.) away!".

The paradigm of the $i$-type perfect recorded from BWA informants is almost identical to that of group I, however (De Jong 2000:201).

\begin{tabular}{|c|c|c|}
\hline \multicolumn{3}{|c|}{ "forget" } \\
\hline & perfect & \\
\hline & sg. & pl. \\
\hline 3. masc. & nisíy & nisyuw \\
\hline fem. & nisyat & nisyin \\
\hline 2. masc. & nisīt & nisītuw \\
\hline em. & nisītiy & nisītin \\
\hline com. & nisit & nisina \\
\hline
\end{tabular}

N.B. $i$ in the first syllable of these verbs is not elided.

3.2.2.5.2. Verbs $C_{3}=\mathrm{y}($ tertiae infirmae) imperfect

\begin{tabular}{lllll}
\multicolumn{3}{c}{ "forget" } & \multicolumn{3}{c}{ "go, walk" } \\
& \multicolumn{2}{c}{ a-type imperfect* } & \multicolumn{2}{c}{ i-type imperfect } \\
& sg. & pl. & SG & PL \\
3. masc. & yansi & yansuw & yimšiy & yimšuw \\
fem. & tansi & yansin & timšiy & yimšin \\
2. masc. & tans & tansuw & timš /-iy & timšuw \\
fem. & tansiy & tansin & timšiy & timšin \\
1. com. & ansi & nansi & imšiy & nimšiy
\end{tabular}

* Verb forms are listed here in their unsuffixed shapes; when suffixed, $i>\bar{a}$, as in e.g. yansāhi "he forgets her" (contrast with remark in ${ }^{* 2}$ on treatment of final $-i$ ' in $\check{g} i$ ' "he came" in 3.2.2.6.1.).

N.B. Apocopated tertiae infirmae 2nd p. sg. masc. imperfect forms are very regular in group VI. Other examples are ag!labiyyah lliy btalghuw sakanuw fi wiǧih gibil așȘa ¿d "the majority of those you find settled down in the south in Upper Egypt", hatläguh "you'll find him", aw'a tans! "don't you forget!" and iw biti: $\dot{g} l u h$ "and you boil it (a long time)".

3.2.2.5.3. Verbs $C_{3}=\mathrm{y}($ tertiae infirmae) imperatives

Like apocopated imperfect forms for the 2nd p. sg. masc., apocopated imperative forms for sg. masc. are currrent, e.g. írimhi' "throw it (sg. fem.) away!", ansuh "forget him!". 
3.2.2.5.4. Verbs $C_{3}=\mathrm{y}$ (tertiae infirmae) participles

Active participles have the patterns $C_{1} \bar{a} C_{2} i y, C_{1} \bar{a} C_{2} y i h, C_{1} \bar{a} C_{2} y \bar{n}$ and $\mathrm{C}_{1} \overline{\mathrm{a}} \mathrm{C}_{2} \mathrm{yāt}$. E.g. lāgiy, lāgyih, lāgyìn, lāgyāt "having found".

3.2.2.5.5. Verbs $C_{3}=\mathrm{y}$ (tertiae infirmae) verbal nouns

No instances of verbal nouns of tertiae infirmae were recorded.

3.2.2.6. The verb "come"

3.2.2.6.1. The verb "come" perfect and imperfect

\begin{tabular}{|c|c|c|c|c|}
\hline \multirow{2}{*}{ "come" } & \multicolumn{2}{|l|}{ perfect $^{*_{1}}$} & \multicolumn{2}{|l|}{ imperfect $^{*_{1}}$} \\
\hline & sg. & pl. & sg. & pl. \\
\hline 3. masc. & $\check{g} i^{* *_{2}}$ & ğuw & yiǧı́ $y^{* 4}$ & yiǧúw \\
\hline fem. & $\check{g} \bar{a} t$ & $\operatorname{ğ}$ n $^{* 3}$ & tiǧ́n & yiǧı́n \\
\hline 2. masc. & ǧit & ǧituw & $t_{i g}{ }^{*_{5}}$ & tiğúw \\
\hline fem. & ǧitiy & ğțtin ${ }^{* 3}$ & tiǧı́y & tiǧín \\
\hline 1. com. & ǧit & ǧine' & iğı́y ${ }^{* 6}$ & niǧíy \\
\hline
\end{tabular}

${ }^{*}$ Apart from stress in the imperfect paradigm, these forms are reminiscent of forms heard in the dialect of Biliy (see De Jong 2000:204).

*2 But when suffixed: hū ğāni "he came to me", but both $h \bar{u} \check{g}^{u} \bar{a}^{u} k$ and $h \bar{u}$ $\check{g}^{\prime}{ }^{u} k$ (i.e. not with IPA [ir], but with lengthened [i]: [dzis $\left.{ }^{\mathrm{u}} \mathrm{k}\right]$ ) were heard for "he came to you (sg. masc.)" and also hü ǧi:k (IPA [dzık ]) "he came to you (sg. fem.)".

${ }^{*} n$ is doubled when followed by a vowel-initial pronominal suffix, as in tiğínnu fi dāruh and ğîtínnu fi dāruh, and also doubling of the $n$ when followed by a consonant-initial suffix, including those of the 2nd p. sg.: ğinnuk / ğinnik "they (fem.) came to you sg. masc. / sg. fem.".

*4 In rapid speech byiǧı́y may be realized as biǧı́y, making it homophonous with the form for 1st p. sg. com., e.g. fi șșayf biğ'íy rịh kițìr, iw fìh $f i$ Imašti byiǧíy rịh kițir "in summer a lot of wind comes, and there are (times also) in winter that a lot of wind comes".

$*_{5}$ Notice the apocopated imperfect form for the 2nd. p. sg. masc., which is in complete conformity with the treatment of tertia yā' verbs.

*6 The form ağíy came out through direct elicitation in MzA, but the form iǧ́y is more logical and was indeed recorded regularly in MzA and also in BWA.

3.2.2.6.2. The verb "come" imperatives

Imperatives used with the verb "come" are: ta'āl, ta'äliy, ta'äluw, ta'älin. 
3.2.2.6.3. The verb "come" participles

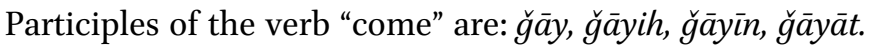

3.2.2.7. Verbs $C_{2}=C_{3}$ (mediae geminatae)

3.2.2.7.1. Verbs $C_{2}=C_{3}$ (mediae geminatae) perfect and imperfect

"stretch"

$$
\text { perfect* imperfect }
$$

$\begin{array}{llll}\text { sg. } & \text { pl. } & \text { sg. } & \text { pl. }\end{array}$

3. masc. madd madduw ymidd ymidduw

fem. maddat maddin tmidd ymiddin

2. masc. middèt middètuw tmidd tmidduw

fem. middētiy middētin tmiddiy tmiddin

1. com. middēt middēna imidd nmidd

* Raising of $a$ in closed syllable preceding stressed $\bar{e}$ is regular (like in the dialect of Biliy of group I in the north and also in groups $\mathrm{II}^{78}$ and VII. See also remark to the perfect paradigm in $3.2 .3 \cdot 5.2$.

When the geminate is velarized, the $\bar{e}$ of the ending is diphthongal $a y$, as in e.g. hattayt "I placed". $a$ in closed syllable preceding ay is not raised. When the geminate is velarized, the imperfect usually has $u$ as a base vowel, e.g. yhutț "place".

3.2.2.7.2. Verbs $C_{2}=C_{3}$ (mediae geminatae) imperatives

Imperatives of mediae geminate verbs are e.g. šidd, šiddiy, šidduw, šiddin "pull!" and with base vowel u: ḥuțt, hutțiy, huutțtuw, huuțtin "place!".

3.2.2.7.3. Verbs $C_{2}=C_{3}$ (mediae geminatae)

Active participles geminate verbs are e.g.: mādd, māddih, māddīn, māddāt.

Passive participles may be subject to the gahawah-rule when $C_{1}=X$, e.g. mahațūt "placed", but this was not heard in maxṣūṣ "special".

\subsubsection{Derived measures}

\subsubsection{Measure n-1}

\subsection{Measure n-1 sound roots}

Measure $n-1$ is used to express the passive. The underlying patterns are anC $\mathrm{aC}_{2} \mathrm{aC}_{3}$, yinC $\mathrm{aC}_{2} \mathrm{iC}$. The vowel of the preformative (in both perfect and imperfect) may be stressed in positions eligible for stress and surface

\footnotetext{
${ }^{78}$ For the dialect of Biliy, see De Jong 2000:205. For group II, see ibid.:309.
} 
forms often show raised $a$, e.g. ángița', yíngiți "be cut", ánwikal, yínwikil "be eaten". The paradigms are:

\begin{tabular}{|c|c|c|c|c|}
\hline & perfect & & imperfect* & \\
\hline & & pl. & sg. & pl. \\
\hline 3. masc. & ánbiṣaț & inbáșațuw & yínbișit & yinbáștuw \\
\hline fem. & inbáṣațat & inbáṣațin & tínbișit & yinbáșțin \\
\hline 2. masc. & inbașáțt & inbașáțtuw & tínbișit & tinbáșțuw \\
\hline $\begin{array}{l}\text { fem. } \\
\text { com. }\end{array}$ & $\begin{array}{l}\text { inbașáțtiy } \\
\text { inbasátt }\end{array}$ & inbașáțtin & tinbáștity & tinbáșțin \\
\hline & ınbașațt & inbașátna & inbișiț & ninbișiț \\
\hline
\end{tabular}

* In the imperfect forms the underlying $|\mathrm{a}|$ 'reappears' in syllables closed by $\mathrm{C}_{2}$ (here $s$ ) after elision of $i$ preceding $\mathrm{C}_{3}$ (here $t$ ). The fact that the $i$ preceding $s$ is actually underlying $|\mathrm{a}|$ can also be concluded from the fact that it is not elided from forms like yinbișit (i.e. the form is not yin(i)bșit; a form which would be analogous in terms of elision and anaptyxis to a form like yikitbuw). In a similar manner, the participles are formed using the underlying pattern $\operatorname{minC}_{1} \mathrm{aC}_{2} \mathrm{iC}_{3}$, e.g. mínbișiț, minbașțah, minbașțin, minbaștāt "rejoicing".

The inflectional base of the verb has been reinterpreted as underlying |inbașiț|, instead of |nbașiț|; verbal prefixes are then vowelless (i.e. $y$-, $t$ - and $n$-) and for the ist p. sg. com. the prefix is $\varnothing$ (see also below inša $\bar{l}$ in 3.2.3.1.3.).

\subsection{Measure n-1 $C_{2}=C_{3}$ (mediae geminatae)}

Patterns for perfect and imperfect of measure $n$-1 of medial geminate verbs are: $\operatorname{inC}_{1} \mathrm{aC}_{2} \mathrm{C}_{3}$ and yinC $\mathrm{aC}_{2} \mathrm{C}_{3}$, e.g. inhațt, yinhatt "be placed" and inșabb, yinșabb "be poured". ${ }^{79}$

\subsection{Measure $\mathrm{n}-1 C_{2}=\mathrm{y}$ or $\mathrm{w}$ (mediae infirmae)}

The patterns for perfect and imperfect of measure $n-1$ of medial weak verbs are: $\operatorname{inC}_{1} \bar{a} C_{3}$ and yinC $\bar{a}_{1} C_{3}$, e.g.

"be carried"

\begin{tabular}{|c|c|c|c|c|}
\hline & perfect & & imperfe & \\
\hline & & pl. & sg. & pl. \\
\hline 3. masc. & inšāl & inšāluw & yinšāl & yinšāluw \\
\hline fem. & inšālat & inšālin & tinšāl & yinšālin \\
\hline 2. masc. & inšilt & inšiltuw & tinšāl & tinšāluw \\
\hline $\begin{array}{l}\text { fem. } \\
\text { com. }\end{array}$ & $\begin{array}{l}\text { inšiltiy } \\
\text { inšilt }\end{array}$ & $\begin{array}{l}\text { inšiltin } \\
\text { inšilne }\end{array}$ & $\begin{array}{l}\text { tinšāliy } \\
\text { inšāl* }\end{array}$ & $\begin{array}{l}\text { tinšālin } \\
\text { ninšāl }\end{array}$ \\
\hline
\end{tabular}

* Notice the absence of vowel harmony, and the paradigmatically fixed intital $i$ -

${ }^{79}$ It is unsure whether the initial vowel of the perfect is $a$ - (i.e. anhatt $)$ or $i$-. 
3.2.3.1.4. Measure n-1 $C_{2}=\mathrm{y}$ or $\mathrm{w}$ (mediae infirmae) participles

Participles are shaped on the pattern $\operatorname{minC}_{1} \overline{\mathrm{a}} \mathrm{C}_{3}:$ minšăl, minšālah, minšā $\bar{l} \bar{n}$, minšālāt "carried away, removed".

\subsubsection{Measure t-1}

No instances of measure $t$-1 were recorded in these dialects.

\subsubsection{Measure 1-t}

\subsection{Measure 1-t sound roots}

Underlying patterns for measure $1-t$ are: $\mathrm{aC}_{1} \operatorname{taC}_{2} \mathrm{aC}_{3} \mathrm{yiC}_{1} \operatorname{taC}_{2} \mathrm{iC}_{3}$. Like in measure $n-1$, raised $a$ is found in unstressed syllables of the surface forms, e.g.: áštigal, yíštigil "work", áttifag, yíttifig "agree" and ástuwa, yístiwiy "ripen; be cooked (of food)". Paradigms for $\mathrm{C}_{3}=y$ are:

\begin{tabular}{|c|c|c|c|c|}
\hline \multirow{2}{*}{ "buy" } & \multicolumn{2}{|l|}{ perfect } & \multicolumn{2}{|c|}{ imperfect } \\
\hline & & pl. & sg. & pl. \\
\hline 3. masc. & áštara & áštaruw & yíštiriy & y'šstiruw \\
\hline & áštarat & áštarịn & tiśstiriy & y'šstirin \\
\hline 2. masc. & ištarayt & ištaraytuw & tišstiriy & tístiruw \\
\hline fem. & ištaraytiy & ištaraytin & tíštiriy & tísstirin \\
\hline 1. com. & ištarayt & ištarayna & ištiriy & nístiriy \\
\hline
\end{tabular}

3.2.3.3.2. Measure 1-t $C_{2}=\mathrm{w}$ or y (mediae infirmae)

An example of a medial weak measure 1-t verb is $i h t \bar{a} g$, yiḥtāğ "need".

3.2.3.3.3. Measure 1-t $C_{2}=C_{3}$ (mediae geminatae)

An example of a medial geminate measure 1-t verb is itazz, yitazz (bi) "be proud (of)".

\subsection{Measure 1-t participles}

Patterns for measure 1- $t$ participles are $\mathrm{miC}_{1} \mathrm{tiC}_{2} \mathrm{iC}_{3}$ (underlying $\mathrm{miC}_{1} \mathrm{taC}_{2} \mathrm{iC}{ }_{3}$ ), $\operatorname{miC}_{1} \operatorname{taC}_{2} \mathrm{C}_{3} \mathrm{ah} / \mathrm{ih}, \mathrm{miC}_{1} \operatorname{taC}_{2} \mathrm{C}_{3} \overline{\mathrm{n}}, \mathrm{miC}_{1} \operatorname{taC}_{2} \mathrm{C}_{3} \overline{\mathrm{a}} \mathrm{t}$.

Examples are: míśtigil "working", miftársih "predatory (of animals)", místiwiy "ripe, cooked (sg. masc.)", mistáwyih "ripe cooked (sg. fem.)". mittifig "agreed (sg. masc.)", mittafgāt "agreed (pl. fem.)" and mítiniy "taking care of, providing for".

Examples of participles of medial geminate and medial weak verbs are: miḥtāğ "in need", miltammin "having gathered (pl. masc.)".

One example of a passive 1-t participle is mittahamin "accused (pl. masc.)" (cf. C.A. root $w-h-m)$. 


\subsubsection{Measure ista-1}

\subsection{Measure ista-1 sound roots}

Like measure 2, measure ista-1 has morphologically alternating short vowels: $a$ in the perfect and $i$ in the imperfect. The paradigms are:

$\begin{array}{lllll} & \text { "ask for information" } & & \\ & \text { perfect } & & \text { imperfect } & \\ & \text { sg. } & \text { pl. } & \text { sg. } & \text { pl. } \\ \text { 3. masc. } & \text { istafham } & \text { istafhamuw } & \text { yistafhim } & \text { yistáfihmuw } \\ \text { fem. } & \text { istafhamat } & \text { istafhamin } & \text { tistafhim } & \text { yistáfihmin } \\ \text { 2. masc. } & \text { istafhamt } & \text { istafhamtuw } & \text { tistafhim } & \text { tistáfihmuw } \\ \text { fem. } & \text { istafhamtiy } & \text { istafhamtin } & \text { tistáfihmiy } & \text { tistáfihmin } \\ \text { 1. com. } & \text { istafhamt } & \text { istafhamna } & \text { astafhim } & \text { nistafhim }\end{array}$

3.2.3.4.2. Measure ista-1 $C_{2}=\mathrm{y}$ (mediae infirmae)

Measure $i s t a-1$ verbs of medial weak roots were not recorded.

3.2.3.4.3. Measure ista-1 $C_{3}=\mathrm{y}$ (tertiae infirmae)

Measure ista-1 verbs of final weak roots were not recorded.

3.2.3.4.4. Measure ista-1 verbs $C_{2}=C_{3}$ (mediae geminatae)

Patterns for medial geminate measure ista-1 verbs are: istaC $\mathrm{aC}_{2} \mathrm{C}_{3}$, yistaC $\mathrm{iC}_{2} \mathrm{C}_{3}$, an example is $(i)$ sta 'add, yista idd "prepare oneself".

Short $a$ in the perfect preceding stressed $\bar{e}$ may be raised (e.g. ista $a d d \bar{e} t$ $>$ ista iddèt), see also remarks in 3.2.2.7.1. and 3.2.3.5.2.

\subsection{Measure ista-1 participles}

Participles of measure ista-1 verbs have the pattern mistaC $\mathrm{C}_{2} \mathrm{iC}_{3}$, e.g. mista ǧil "in a hurry".

For mediae geminatae the pattern is $\operatorname{mistaC}_{1} \mathrm{iC}_{2} \mathrm{C}_{3}$ : mista idd "having prepared, ready".

\subsubsection{Measures 2 and $\mathrm{t}-2$}

Measure 2 has morphologically alternating short vowels: $a$ in the perfect and $i$ in the imperfect. The patterns are: $\mathrm{C}_{1} \mathrm{aC}_{2} \mathrm{C}_{2} \mathrm{aC}_{3}, \mathrm{yC}_{1} \mathrm{aC}_{2} \mathrm{C}_{2} \mathrm{iC}_{3}$.

Measure $t$-2 has morphologically fixed $a$. The patterns are $\operatorname{taC}_{1} a_{2} C_{2} a_{3}$, $\mathrm{ytaC}_{1} \mathrm{aC}_{2} \mathrm{C}_{2} \mathrm{aC}$.

\subsection{Examples of measure 2 sound roots}

Like in group I, the high vowel $i$ of imperfect measure 2 may be elided in open syllables. The inital geminate of the resulting cluster may then be reduced. Examples are: yzabbțuw "they do a proper job", bitțall'uw gișāyid "you (pl. masc.) recite (lit. bring up) poems", biybarrkuw 'așill "they let a throughbred cover", the latter in I.P.A. [bi ${ }^{\mathrm{j}^{\prime}}$ barkow $\left.\mathrm{Pa}^{\mathrm{e}} \mathrm{s}^{\mathrm{e}} \mathrm{i} \mathrm{l}\right]$. 
Similar elisions may take place in sandhi, as in thamms ilbunn "you roast the coffee beans" and $w$ itxalliy tğammr išwayyih "and you let it (burn) a little (to) become glowing embers".

$r$ or $l$ following the high vowel $i$ may inhibit its morphophonemic elision, e.g. itfassiruh "you explain it" and biy'assirin im úk išwayyih "they (pl. fem.) have some influence on you".

When $\mathrm{C}_{2}=\mathrm{C}_{3}$, the elision of $i$ does not take place, but the geminate may be reduced, e.g. thálliluh "you analyze it" (I.P.A. [ət'halıl $\left.\mho^{\mathrm{h}}\right]$ ).

\subsection{Measure 2 tertiae infirmae}

Paradigms for measure 2 tertiae infirmae verbs are:

$\begin{array}{lllll} & \text { perfect }{ }^{* 1} & & \text { imperfect } & \\ & \text { sg. } & \text { pl. } & \text { sg. } & \text { pl. } \\ \text { 3. masc. } & \text { sawwi* } & \text { sawwuw } & \text { ysawwiy } & \text { ysawwuw } \\ \text { fem. } & \text { sawwat } & \text { sawwin } & \text { tsawwiy } & \text { ysawwin } \\ \text { 2. masc. } & \text { suwwēt } & \text { suwwētuw } & \text { tsaww/-iy } & \text { tsawwuw } \\ \text { fem. } & \text { suwwētiy } & \text { suwwētin } & \text { tsawwiy } & \text { tsawwin } \\ \text { 1. com. } & \text { suwwēt } & \text { suwwēni } & \text { asawwiy } & \text { nsawwiy }\end{array}$

${ }^{* 1}$ For raising of $a$ in closed syllable preceding stressed $\bar{e}$ see remark in 3.2.2.7.1.

${ }^{*}$ Like in forms of the imperfect (see remark * in 3.2.2.5.2.) final $-i^{\prime}>-\bar{a}$ when suffixed, e.g. sawwāh "he did it".

\subsection{Examples of measure 2 primae hamzah}

The verb "feed" is wakkal, ywakkil, e.g. hatta mā ywakklūne \# "so that they wouldn't give us food", gi adna šaharayn, fi lğbāl hādiy binḥūm. innās kānat bitxāf itwakkilne "we stayed two months in these mountains as we moved around. People were afraid to give us food".

\subsection{Measure t-2 imperfect and perfect}

In measure $t$-2 the vowel $a$ is morphologically fixed for the perfect and imperfect. Patterns are $\operatorname{taC}_{1} \mathrm{aC}_{2} \mathrm{C}_{2} \mathrm{aC}, \mathrm{ytaC}_{1} \mathrm{aC}_{2} \mathrm{C}_{2} \mathrm{aC}$.

Unlike the situation in group I dialects (especially so in those of the Rmēlāt and Sawārkah, see De Jong 2000:212), the ta-prefix in the perfect and imperfect of measure $t-2$ is stable and is hardly ever reduced to $(i) t$ -

When the imperfect preformative $t$ - of the $3 \mathrm{rd} \mathrm{p}$. sg. fem. and of the 2 nd. p. sg. and pl. masc. and fem. precedes, the resulting sequence tta- is reduced to $t a-.^{80}$ For tertiae infirmae $t-2$ verbs the paradigms are:

\footnotetext{
${ }^{80}$ I have referred to this before as a haplological drop of the verbal prefix $t a$ - (from an initial sequence $\left.{ }^{*} t a t a-\right)$. This interpretation however pre-supposes verbal imperfect pre-
} 
"have lunch"

\begin{tabular}{|c|c|c|c|c|}
\hline & perfect $^{*_{1}}$ & & imperfect* & \\
\hline & sg. & pl. & sg. & pl. \\
\hline 3. masc. & tag்addi & tag்adduw & ytag்addi & ytag்adduw \\
\hline fem. & tag்addat & tag்addin & tajaddi & ytag்addin \\
\hline 2. masc. & tagaddēt & tag்addētuw & tagadd ${ }^{* 2}$ & tag்adduw \\
\hline fem. & taġaddētiy & taġaddētin & tag்addiy & tag்addin \\
\hline 1. com. & tagiaddēt & taġaddēni’ & atag்addi' & ntagiaddi \\
\hline
\end{tabular}

*1 With a verb like ta'ašša, yta'ašša "have dinner" raising of $a$ in the ta-

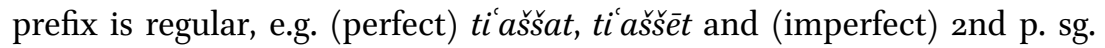
masc. ti aššs.

Notice that the 3 rd. p. pl. masc. and fem. of the perfect have become homophonic with the 2nd p. pl. masc. and fem. (respectively) of the imperfect. And the 3 rd p. sg. masc. of the perfect is homophonic with the 3rd. p. sg. fem. of the imperfect.

Raising of final * $-\bar{a}$ is indicated here as $-i \dot{ }$, but phonetic values may also be slightly lower (i.e. nearer to I.P.A. $\left[\mathrm{e}^{\text {? }}\right]$ ).

$*_{2}$ Notice also apocopation.

\subsection{Measures 2 and $\mathrm{t}-2$ verbal nouns}

Verbal nouns for measure 2 have a taC $\mathrm{C}_{2} \mathrm{C}_{3}$ pattern, e.g. tağlīb "throwing out (of a fish line)", taybīs "drying (trans.)", tadrīb "training (trans.)" and a gahawah-form tahadīr "coming down".

$\mathrm{A}_{3}=y$ verbal noun is found in tirbàt álğimal "training the camel".

Verbal nouns for measure $t$-2 were not recorded. For the quadriliteral verb ta'aknan, yta'aknan "be annoyed", however, the verbal noun tiknin was recorded.

\subsection{Measures 2 and t-2 participles}

Active participles of measure 2 have a $\mathrm{mC}_{1} \mathrm{aC}_{2} \mathrm{C}_{2} \mathrm{iC}_{3}$ (-ih/-ah, -īn, -āt) pattern, e.g. m'aggid "travelling", m'allig "keeping suspended", for $\mathrm{C}_{3}=y$ msawwiy, msawwyih etc., "making, doing" and for $\mathrm{C}_{2}=\mathrm{C}_{3}$ mğaddid, mğaddidih (without elision of the short vowel $i$ ), etc. "renewing".

The pattern for the passive measure 2 participle is $\mathrm{mC}_{1} \mathrm{aC}_{2} \mathrm{C}_{2} \mathrm{aC}_{3}$ (-ih/-ah, -īn, -āt), e.g.: mlawwan "coloured", mnaššaf "dried, hardened" and mtallal "piled up", for $\mathrm{C}_{3}=y$ msawwa, msawwayih etc., "made, done" and for $\mathrm{C}_{2}=\mathrm{C}_{3}$ mğaddad, mğaddadih etc. "renewed".

fixes like $t a-, y a$-, and $n a$-, whereas these are actually $t$-, $y$ - and $n$ - (the latter two implying the first). The interpretation of reduction of the initial geminate is therefore preferred here. 
The pattern for measure $t$-2 active participles is $\operatorname{maC}_{1} \mathrm{aC}_{2} \mathrm{C}_{2} \mathrm{iC}_{3}$ (-ih/-ah, -īn, -āt), but in participles often the $t a$ - prefix has been reduced to $t$ - (pattern mitC $\mathrm{aC}_{2} \mathrm{C}_{2} \mathrm{iC}_{3}$ (-ih/-ah, -īn, -āt), e.g. mit’așșil "deep-rooted", mithaddir (min) "originating (from)", mitğawwiz "married" and for $\mathrm{C}_{3}=y$ ) mtaǵaddiy, mtagaddyih etc. "having eaten lunch" and also mitharriy, mitharryih etc. "striving for, aspiring".

\subsubsection{Measures 3 and $\mathrm{t}-3$}

Like measure 2, measure 3 has morphologically alternating vowels: $i$ in the imperfect and $a$ in the perfect. Patterns for measure 3 are: $\mathrm{C}_{1} \overline{\mathrm{a}} \mathrm{C}_{2} \mathrm{aC}_{3}$, $\mathrm{yC}_{1} \overline{\mathrm{a}} \mathrm{C}_{2} \mathrm{iC}$.

Measure $t-3$ has morphologically fixed $a$ in the perfect and imperfect, and like in measure $t$-2, the $t a$-preformative is not often reduced to $t$-. Patterns for measure $t-3$ are: $\operatorname{taC}_{1} \bar{a} C_{2} a_{3}, y \operatorname{taC}_{1} \bar{a} C_{2} i C_{3}$.

Also like in measure $t-2$, the $t a$ - preformative of measure $t-3$ in the perfect is usually not reduced to $(i) t$ -

3.2.3.6.1. Examples of measures 3 and $\mathrm{t}-3$

Paradigms for measure 3 are:

\begin{tabular}{|c|c|c|c|c|}
\hline \multicolumn{5}{|c|}{ "quarr } \\
\hline & & pl. & sg. & pl. \\
\hline 3. masc. & kāwan & kāwanuw & $y k \bar{a} w i n$ & $y k \bar{a} w n u w$ \\
\hline fem. & kāwanat & kāwanin & tkāwin & $y k \bar{a} w n i n$ \\
\hline 2. masc. & kāwant & kāwantin & tkāwin & tkāwnuw \\
\hline fem & kāwantiy & kāwantuw & tkāwniy & tkāwnin \\
\hline . com. & kāwant & kāwanna & akāwin & nkāwin \\
\hline
\end{tabular}

Some suffixed examples are: suffixed: kāwanatuh (stressed on first syllable) "she quarrelled with him", kāwannāh "we quarrelled with him", kāwantinnuh "you (pl. fem.) quarrelled with him" and (imperfect) tkāwnīh "you (sg. fem.) quarrel with him", ykāwninnuh "they (fem.) quarrel with him", $y k \bar{a} w n \bar{u} h$ "they (masc.) quarrel with him".

$\mathrm{A}_{3}=y$ verb has the following paradigms:

\begin{tabular}{|c|c|c|c|c|}
\hline & perfect & & imperfect & \\
\hline & sg. & pl. & sg. & pl. \\
\hline 3. masc. & lāga & lāguw ${ }^{*_{1}}$ & ylāgiy & ylāguw \\
\hline fem. & lāgat & lāgin $^{* 1}$ & tlāgiy & ylägin \\
\hline 2. masc. & lāgèt & lāgētuw & $t \bar{a} g^{* 2} /-i y$ & tlāguw \\
\hline fem. & lāgētiy & lāgētin & tlāgiy & tlāgin \\
\hline 1. com. & lāgèt & lāgēna & alāgiy & nlāgiy \\
\hline
\end{tabular}


$*_{1}$ Notice the absence of vowel harmony in the endings: - uw and -in instead of -aw and -an current in group I.

$*_{2}$ Apocopated 2nd p. sg. masc. imperfect forms also occur in measure 3.

Some examples of suffixed forms are: hū lāgāh "he met/found him", hì lāgát"k "she met/found you (sg. masc.)", hì lāgatuh "she met/found him" (cf. 3.1.10.5.) and hinnah biyläginnuk/-innik "they meet/find you (sg. masc./fem.)".

Examples for measure $t-3$ are: [kān] bintarāfag iw bintasābag "we used to travel together and race together" and (for $\mathrm{C}_{3}=y$ ) bukrah hantalāga "tomorrow we'll meet", huwwa ytalāguw "they meet", intin talāgin (like in measure $t$-2, initial $t t a$ - is reduced to $t a-$, cf. 3.2.3.5.4.) "you (pl. fem.) meet". The vowel $a$ preceding stress may be raised, as in the example yti $\bar{a} l a g$ "he receives medical treatment" and the perfect tihâlafuw "they became allies".

Notice again the absence of vowel harmony in the 3 rd and 2nd p. pl. masc. and sg.: $-u w$ and -in, contrasting with -aw or -ow and -an in group I.

\subsection{Measures 3 and t-3 participles}

Active participles of measure 3 have the pattern $\mathrm{mC}_{1} \bar{a}_{2} \mathrm{iC}_{3}(-\mathrm{ih} /-\mathrm{ah}$, -inn, -āt), e.g. mğăhdīn "fighting (pl. masc.) in a ğihàd", $m k \bar{a} f^{\prime}{ }^{\prime}{ }^{2}$ "compensating (sg. fem.)".

A passive participle (pattern $\mathrm{mC}_{1} \overline{\mathrm{a}} \mathrm{C}_{2} \mathrm{aC}_{3}$ ) is mtāaradin "having been pushed back (in a fight)".

Active participles of measure $t$-3 have the pattern $\operatorname{mtaC}_{1} \bar{a} C_{2} i_{3}$ or mitC $_{1} \bar{a}_{2} \mathrm{iC}_{3}(-\mathrm{ih} /$-ah, -īn, -āt); like in participles of measure $t$-2 (cf. 3.2.3.5.6.), the $t a$ - preformative is often reduced to $(i) t$-. Both mtawāğdih and mitwāğdih "present (sg. fem.)" were recorded and also mithāyig lay "it seems to me" (cf. MSA root h-y-').

\subsection{Measures 3 and $\mathrm{t}-3$ verbal nouns}

A verbal noun for measure 3 that was recorded is ǧihād "war against unbelievers" and another is $m s \bar{a}$ 'adah "help, assistance". Verbal nouns of the type $\mathrm{tC}_{1} \mathrm{e} \mathrm{C}_{2} \mathrm{iC}$ were not recorded. ${ }^{81}$

\subsubsection{Measure 4}

\subsection{Measure 4 sound roots perfect and imperfect}

Like in many Bedouin dialects of Sinai, verbal measure 4 is found in group VI as well.

\footnotetext{
${ }^{81}$ Such as they have been reported for the dialect of the Ahaywāt of group I, see Stewart 1990: 186 (text 69) and 118 (text 37).
} 
The patterns are $\mathrm{aC}_{1} \mathrm{C}_{2} \mathrm{aC}_{3}$ for the perfect and $\mathrm{yiC}_{1} \mathrm{C}_{2} \mathrm{iC}_{3}$. The paradigms are:

\begin{tabular}{|c|c|c|c|c|}
\hline \multirow{6}{*}{$\begin{array}{l}\text { 3. masc. } \\
\text { fem. } \\
\text { 2. masc. } \\
\text { fem. }\end{array}$} & \multicolumn{2}{|l|}{ perfect } & \multicolumn{2}{|c|}{ imperfect $^{*_{2}}$} \\
\hline & sg. & pl. & sg. & pl. \\
\hline & áfțar & áfțaruw ${ }^{* 1}$ & yifțir & y'fițun \\
\hline & áftarat & áfțarin ${ }^{* 1}$ & tifțir & yifitrin \\
\hline & ifțart & ifțartuw & tifțir & tíftitruw \\
\hline & ifțartiy & ifțartin & tífitriy & tíftitrin \\
\hline 1. com. & ifțart & ifțarna & ifțir & nifțir \\
\hline
\end{tabular}

*1 Notice again the absence of vowel harmony in the endings

$*_{2}$ The anaptyctic vowel in forms like (here underlined) tifitruw and $y$ ffitrin is voiceless and therefore barely audible.

3.2.3.7.2. Measure ${ }_{4} C_{2}=\mathrm{w}$ or y (mediae infirmae) perfect and imperfect Patterns for measure 4 mediae infirmae are: $\mathrm{C}_{1} \overline{\mathrm{a}} \mathrm{C}_{3}\left(\mathrm{C}_{1} \mathrm{iC} \mathrm{t}_{3}\right) \mathrm{yC}_{1} \overline{\mathrm{1}} \mathrm{C}_{3}$, e.g. ra $\bar{a} d$ "he wanted", ridt (I.P.A. [rit:]) "I wanted", yrid "he wants". The paradigms are like those of $\check{s} \bar{a} l, y \check{s} \breve{l}$ (

Some examples of suffixed forms are: rādatih "she wanted him", ridnāh "we wanted him", intuw ridtūh "you (pl. masc.) wanted him", intin ridtinnuh "you (pl. fem.) wanted him" and rādinnuh "they (fem.) wanted him".

3.2.3.7.3. Measure $4 C_{3}=\mathrm{y}$ (tertiae infirmae) perfect and imperfect The patterns for measure $4 \mathrm{C}_{3}=y$ (tertiae infirmae) are $\mathrm{aC}_{1} \mathrm{C}_{2} \mathrm{a}$ (perfect) and $\mathrm{yiC}_{1} \mathrm{C}_{2}$ iy (imperfect). The paradigms are:

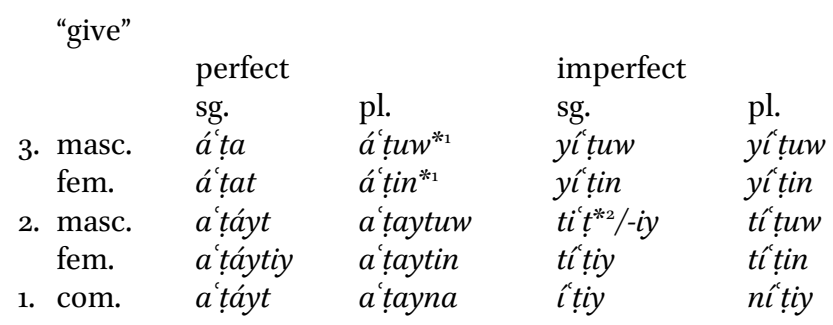

*1 Notice the absence of vowel harmony in the endings in tertiae yầ perfects as well: $-u w$ and -in instead of -aw and -an current in group I.

${ }^{*}$ Notice the presence of the apocopated 2 nd p. sg. masc. forms in measure 4 as well.

Some suffixed examples are: hinnah a ținnuh "they (fem.) gave him" and hinnah a'ținnuh iyyāh "they (fem.) gave it to him". 
3.2.3.7.4. Measure ${ }_{4} C_{1}=\mathrm{w}$ (primae wāw) perfect and imperfect

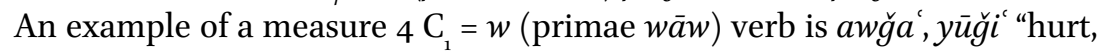
cause pain to", e.g. ibtūğ čuh "it (sg. fem.) hurts him" and 'idñ awğa 'atnī "my ear hurt me".

3.2.3.7.5. Measure ${ }_{4} C_{2}=C_{3}$ (mediae geminatae) perfect and imperfect Verb forms of measure $4 \mathrm{C}_{2}=\mathrm{C}_{3}$ (mediae geminatae) were not recorded, or not recognized as such.

\subsection{Measure 4 imperatives}

Examples of imperatives for measure 4 sound roots are like imperatives for the $i$-type imperfect (see 3.2.1.5.).

Imperatives of $\mathrm{C}_{3}=y$ roots are: $i^{\prime} t$ (apocopated), it tiy, it tuw, it tin. Suffixed examples are: i'ițh-iyyāha "give it (sg. fem.) to her", ițuh luh "give it to him".

\subsection{Measure 4 participles}

The participles for sound roots have a miCCiC pattern, e.g. mifțir, mífțrih, mifițīn, mifitrāt "having eaten breakfast".

For mediae infirmae there are participles of the type $m r \bar{\imath} d,-i h,-\bar{\imath} n,-\bar{a} t$ "wanting". ${ }^{82}$ Another example is $m \dot{g} \bar{\imath}$ " "running".

3.2.3.8. Measure 9

Paradigms for measure 9 are:

\begin{tabular}{|c|c|c|c|c|}
\hline & perfect & & imperfect & \\
\hline & sg. & pl. & sg. & pl. \\
\hline 3. masc. & ihmmarr & ihmarrruw & yihmart & yihmmarruw \\
\hline fem. & ihmarrat & iḥmarrrin & tihmmaṛ? & yihmarrrin \\
\hline 2. masc. & ihmarrrayt & ihmarraytuw & tihmarr & tihmarruw \\
\hline $\begin{array}{l}\text { fem. } \\
\text { 1. com. }\end{array}$ & $\begin{array}{l}\text { ihmarraytiy } \\
\text { ihmarrayt }\end{array}$ & $\begin{array}{l}\text { ihmarraytin } \\
\text { ihmarrayne }\end{array}$ & $\begin{array}{l}\text { tihmarriciy } \\
\text { ahmarr }\end{array}$ & $\begin{array}{l}\text { tihmarrin } \\
\text { nihmarr }\end{array}$ \\
\hline
\end{tabular}

Particples are: miḥmaṛ, -ah, -īn, āt.

3.2.3.9. Quadriliteral verbs

Like measure 2, quadriliteral verbs have morphologically alternating vowels in the imperfect $(i)$ and perfect $(a)$.

\footnotetext{
${ }^{82}$ Though for the verb rād, yrīd measure 1 participles rāyid, -ih etc. were also accepted by my informants.
} 


\begin{tabular}{|c|c|c|c|c|}
\hline & perfect ${ }^{* 1}$ & & imperfec & \\
\hline & sg. & pl. & sg. & pl. \\
\hline 3. masc. & zag்raț & zág்rațuw & yzaġrit & yzáġirțuw \\
\hline fem. & záġrațat & zaǵrațin & tzaǵrit & yzáġirțin \\
\hline 2. masc. & zagratt & zag்rațtuw & tzagritt & tzágirțuw \\
\hline fem. & zaġrattiy & zag்rattin & tzágirțìy & tzágirțin \\
\hline com. & zaǵrattt & zagrațe & azag grit & nzag griț \\
\hline
\end{tabular}

${ }^{* 1} t t$ is assimilated to $t \underline{t}$, e.g. zagratticy.

*2 Initial $t z$ is assimilated to $d z$ or $z z$, e.g. (partially) \# idzagriṭ or (totally) \# izzagriț.

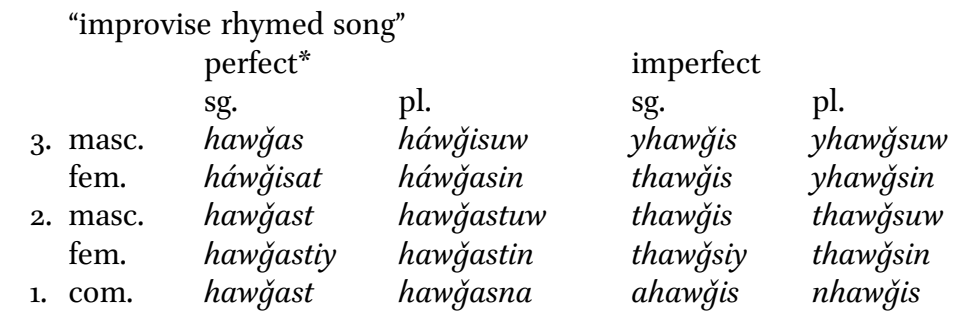

* Forms like hawğisat and hawğisuw show raising of $a>i$ (see 3.1.1.7.).

The verbal noun is hǧèsiy or thĭğis. Similarly, the verb hawğan, yhawğin "improvise rhymed song in public" has verbal nouns hğèniy or thïğin.

\section{Remarks on Phraseology}

\subsection{Nunation}

Tanwin is not a feature of MzA or BWA.

Of course, there are the loans from MSA, which may have come via other dialects, such as masalan "for instance"; the $s$ for *t (in a tā'-speaking dialect!) is a clue that this loan came via a dialect in which interdentals are not part of the phoneme inventory, such as Cairene.

Other examples of such MSA loans with nunation are: tab an "of course", tagrïban "approximately", 'așlan "in origin", filan "indeed, actually" and hâaliyyan "currently".

\subsection{Negation}

Negating a verb is done with $m \bar{a}$ preceding the verb form, although bipartite $m \bar{a}+$ verb form $+\check{s}$ is also used. Of my informants, one speaker 
used $m \bar{a}+$ verb form for more emphatic negation (almost always in combination with $x \bar{a} l i s ̣$ "at all") and the compound negation for 'normal' negation. Another informant, who actually speaks the 'original' dialect better, used the single negation, and only the compound negation by way of exception.

Examples are iw biytarağğuw Imašāyix illiy kān ḥinha mawğūdīn mā ywaddūhuw Falaștīn iywaddūhuw Mașir \# "and they asked the sheikhs, who were there at that time, not to send them to Palestine, (but) to send them to Egypt..." and hād-illiy yainiy btākluh, law mā lihág daktūr aw hāwiy biymūt "and this (person) that he (i.e. a snake) bites, if he doesn't (quickly) get to a doctor or a snake charmer, he dies".

\subsection{The b-imperfect}

The originally sedentary feature of the $b$-imperfect to express the habitual present tense is widespread in Sinai. ${ }^{83}$

Some examples are $i w$ biddugg bi 'ìd ilhōn ingūl 'alēh 'ìd ilhōn, iw ba'ad kidiyyih ... ilbarrāad hü ibyiğliy binhuuțt èh? "and you pound it with the pestle, we call it the pestle, and after that... (when the water in) the teapot is boiling and we put what?" and hù mūhū fāhim kidiy, hü mūhu 'ārif ...innha $m \bar{a}$ bitrìduh "he did not understand this, he did not know ... that she did not want him" w Allah btug ud kidiyyih w bitgahwiy $n n \bar{a} s^{84}$ iw btaxarrafa iw bitğīb ... bithawğis ilkalām illiy zimān "By God, you sit down like this and you give the people coffee (or tea ${ }^{85}$ and you talk and you get ... you improvise the type of talk of old times".

See also remark in 3.2.2.4. on reduction of the diphthong in a form like biyšll > bišll.

\subsection{Future Marker}

To express "volition" or "need" MzA uses bidd + pron. suffix (see also 4.11.). ${ }^{86}$

Often not only volition or need is expressed, but also a sense of futurity of the action expressed in the following verb. Examples are: (futurity)

\footnotetext{
${ }^{83}$ It is current in all dialects of Sinai, except in that of the Dawāgrah, see De Jong 20oo: 224-226, 318-319, 394, 478, 527 and 691 (map 69).

${ }^{84}$ bitgahwiy nnās or bitgahw innās (the latter with apocopation); these two sequences are homophonous.

${ }_{5}$ The verb gahwa, ygahwiy is used for "serve a hot drink", i.e. either coffee or tea.

${ }^{86}$ In contrast, widd is current in group I, see De Jong 2000:238-239.
} 
halhinit bidd-āxd iššuggah $w$ uxušš... w unšur "now I shall take the net and go in (i.e. into the water), and spread it".

To express futurity. the imperfect form may also have prefixed $h a-$, e.g. yainiy halhịin álwalad il'aṣil illiy hü 'indina nihä'... hatlāguh ibyasma' kilamm ubūh "that is, the true son that we have here with us, you will find that he listens to what his father says". In the instances recorded, this hawas invariably used to express inevitability connected to stating a general truth. law istagduw 'a lhikāyah diy, hayagța'-áššiğar, ${ }^{87}$ hayagța'ūh "if they would seek to imitate this (story), they would cut down the trees, they would cut them down".

In the many cases, however, the future is expressed with the simple imperfect, as in intah law ga'att bukrah hinih, ašüfluk wähid iygülluk è ê? 'al-êh? 'ala ttadrïb dih. "If you stay here tomorrow, I'll get you someone who will tell you what? About what? About this training (of camels)".

\section{5. fih "there is / are"}

fih is used to express existence or availability of something, ${ }^{88}$ e.g. iw fih $i$ 'ša $a$ fi lbarr bitdāwiy ssukkar "and there are herbs in the desert which cure diabetes".

The negation is usually $m \bar{a}$ fih (or K-form ma fišs), e.g. $\dot{g} \bar{a} r$ ánnaxal, $m \bar{a}$ fih izrä ah zamān "there were only palm trees, in the old times there was no agriculture".

Also māš may be used for negation (but was only heard in BWA): gab! ilfașil kān yániy ḥwēl alfèn ițtalā ... ya niy māš kațīr "before the seperation there was, that is, around two thousand, three...that is, there was not much" and $w$ Allāhiy māš isdūd fihe ... iblādna hädiy "By God, there are no dams in it... (in) (this) our land".

\subsection{Some Conjunctions}

4.6.1. Conjunctions lamma and yōm

Like in many dialects of Sinai, conjunctions lamma and yōm, or variant forms based on these, are used for "when". ${ }^{89}$

\footnotetext{
${ }_{7}^{8}$ hayagța'uw + aššiğar.

${ }^{88} \mathrm{fih}$ 'functions as a prepositional predicate of a nominal sentence', cf. Grotzfeld 1964:87.

${ }^{89}$ For use of yōm in dialects of northern Sinai, see De Jong 2000:692 (map 71).
} 
4.6.1.1. yōm

\subsubsection{1. yōm used independently}

yōm may be used meaning "when", e.g. yōm lihguw war-álbil, șār ilkōn...yōm șār ilkōn gāmuw gasamuw mi iZwayyid innuṣṣ "when they had caught up with the (tribe who had stolen their) camels, there was a fight. When the fight was over they then ${ }^{90}$ divided (the camels) equally with (Sheikh) Zwayyid". Another example is ya niy kïlu ... ițnēn kïlu yōm ma fiš hawa xäliṣ "(we catch) like a kilo, two kilos when there is no wind at all” and fìh mayyih, halhīn ilğbāl yōm tiğhi', subhāan Allāh rabbna mí tiniy kull šiy "there is water. If you come to the mountains now-God be praised-our Lord takes care of everything".

4.6.1.1.2. yōm in combination with in

\subsection{1. yōmin used independently}

yōmin may also be used for "when", like in the following example: ya'niy kunna šabāb 'ala zzamil w intasābag w insābig yōmin nğ-ál'arab, ${ }^{91}$ fihimt lay $k \bar{e} f$ ? "that is, we were young lads riding camels, and we'd race each other and we'd race and when we'd come to the village, you see what I mean?"

yōmin was only recorded in BWA.

4.6.1.1.2.2. yōmin + obj. suffix as subject of the clause There were no instances of direct suffixing of yōmin.

\subsection{3. $\min$ yōm}

min yōm(in) is often used for "as soon as" or "from the moment that", e.g. kunt fi Mațariyyih sākin, bass bašūf ilǧbālāt hādōlah 'ala 'yūn̄̄ $w$ aná $f i$ Mațariyyih law-ddūnì min yōmin fakkat Sīnih, law kull yōm alf iğnēh mānì $g \bar{a}$ ' $i d$ "I was living in Mațariyya, ${ }^{92}$ but I kept seeing these mountains on my retina (lit. my eyes) while I was in Mațariyya. (even) If they, ever since Sinai was liberated, would have given me a thousand pounds for every day, I would not have stayed (in Mațariyya)".

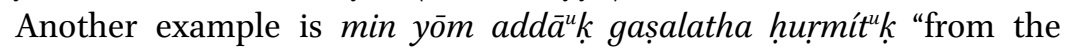
moment that they have given you her twig,93 she's your wife".

${ }^{90}$ gāmuw (lit. "the stood up") is here translated as "then", i.e. like unconjugated gām, which is often used in narrating a chain of events that took place in the past, see De Jong 2000:231.

${ }_{91}^{1}$ nğì + ál-'arab.

${ }_{92}$ Many members of Bedouin tribes in Sinai spent the years of the Israeli occupation of Sinai (following the 1967 war) as refugees in the Egyptian Nile Delta.

${ }^{93}$ A twig is traditionally given to the groom in betrothal ceremonies as a token of the girl's engagement to him. 
4.6.1.1.2.4. min yōm in combination with ma

4.6.1.2. lamma and lumma

Both lamma and its variant lumma (probably a hybrid form of lamma and yōm ma) are often used for "when" and "until".

4.6.1.2.1. lamma and lumma "when" used independently

Examples of lamma used for "when": alhīnit lamma bigūl luk intah min wèn? bitgūl luh ana Mzèniy "now, when he says to you 'Where are you from?' You say to him 'I am a Mzēniy”, inhum gōtaruw hnúh aṣil lamma tfakkir Sìna zamān alblād hèdiy mahál "they went there because when you would see (as it was) before this land was dry".

An example of lumma (current in MzA, but not in BWA) inta lhin

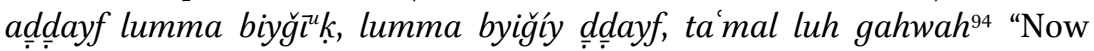
when the guest comes to you, when the guest comes, you make coffee for him".

4.6.1.2.2. lamma + in. lamma or lumma + in was not recorded

4.6.1.2.3. lamma and lumma "until"

lumma (see also remark below in 4.6.1.3.) or lamma may be used in combination with la $\dot{g} \bar{a} y i t$ for "until", e.g. (prosodically lengthened $a$ in the first syllable) la: $\dot{g} \bar{a} y i t$ lumma ddaxanah btabga bẹ $\bar{d} \bar{a}$ " "until (when) the smoke becomes white". But also without laḡayit, as in iw byinhațt luh šwayyih zayy ma tgūl fi ššmis lamma yrūb "and it is placed in the sun a bit, as you say, until it curdles" and bithuțt...ğamir issiyyāl nār lamma táhağam "you put... coal of the acacia tree in the fire (and wait) until it becomes coal". ${ }^{95}$

4.6.1.3. $\operatorname{lōm}(+$ in $)$

An example of lōm + ma was recorded in MzA: iw ğina Diháb nihāniy lōmma midāris fátahin ... "and we came to Dahab here when schools (were) opened". lumma of the preceding paragraph is to be interpreted as shortened lōm+ma.

lòm was not heard in BWA.

\footnotetext{
${ }_{94}$ The last part of the sentence shows Koine influences; instead of ta mal luh gahwah, proper MzA would be more something like itsaww luh gáhawah or tgahwīh.

95 "Become coal" is a gloss from my informant. I could not find a dictionary which lists this verb, but I suppose that the root $h-\check{g}-m$ is in some way related to the root $\breve{g}-m-r$, as in ğamriyyih "glowing ember".
} 
4.6.2. hatta

\subsubsection{1. hatta "until", "so that"}

hatta "until" was recorded in bitdugguh iw biti: $\dot{g} l u h^{96}$ 'ala lmayyih aw mā hatta tiğluh 'a lmayyih "you pound it and boil it in water or water until you boil it in water".

hatta was also recorded meaning "so that": yainiy halhịnit álwalad il'așil illiy hū 'índina nihà'... hatlāguh ibyasma' kilām aḅūh. ibyarḍa' ...ya'niy

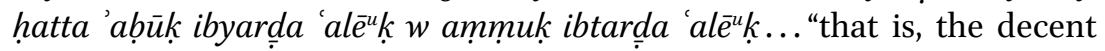
son that we have here (in our community)...you'll find that he listens to (the words of) his father. He is pleased.... that is, so that your father is pleased with you and your mother is pleased with you".

\subsection{Auxiliaries and Verbal Particles}

4.7.1. gām

Unconjugated gām used as a 'marker of consequent action' was not recorded in these dialects. In only one instance (but conjugated) gāmuw was used in a narration of events: yōm șār ilkōn gāmuw yōm liḥguw warálbil, șār ilkōn ... yōm șār ilkōn gāmuww gasamuw mi iZwayyid innuṣṣ "when they had caught up with the (tribe who had stolen their) camels, there was a fight. When the fight was over they then divided (the camels) equally with (Sheikh) Zwayyid".

4.7.2. rāạ

rāh was not recorded as an auxiliary or particle in MzA or BWA.

\subsubsection{Conditional particles}

\subsubsection{Variations on kān as a conditional particle}

4.7·3.1.1. in + kān

An example of in + kān "if": min zilìt iṣgayyir zayy zilìt șaryd aw zilìt ġanám mā y young animal like a young gazelle or a young goat, it is not bad, but if it is from the young gazelle, it is better for the ' $u k k a h$ ". ${ }^{97}$

${ }_{96}$ Prosodic lengthening is here used to express long duration of time, see also 1.2.3.5.

97 A 'ukkah is like a watersack (girbih) made from animal skin, but smaller and made from the skin of a young animal, making the leather smoother. 
4·7·3.1.2. Suffixed inkān

Instances of suffixed kān were not recorded.

4.7·3.1.3. il + kān

Instances of $i l+k \bar{a} n$ were not recorded.

4.7.3.1.4. kān preceded by CA loans iz or iza

An example of kān preceded by iz or iza meaning "if": (a line of poetry) $w$ izkān intuw bitliffūh 'ala miyyih "and if you're going to be around here a hundred (counts)" and ra'āníy[yih]...alimsimmih diyyih. diy iz kān nilgāha fi šgāgni' ... ġār nagța aššuggah kidìy ...w ințuššhi" "a scorpion fish, this venemous one. If we find this in our nets, we have to cut the net like this... and throw it away".

\subsubsection{5. kān as an independent conditional}

An example of kān used independently as conditional "if": iḥna bniftixir bèha hatta kān biygūluw waddiy w hätiy "we are proud of it (sg. fem.) even if they treat us like slaves (lit. they say "bring (this), get (that)!")".

Another example is: law žin ib tafkīr, kān iddarāhim dillih...masalan alḥinit 'ašar $t$-ālāf . . ixlāl arba' $t$-ušhur xamis $t$-ušhur ... il'ašar $t$-alāf dillih talghin 'išrin alf "if it (i.e. the money) came (to you) by brainwork, if this money...for instance it is ten thousand now...over four or five months...you'll find that these ten thousand pounds have become twenty thousand".

4.7.3.1.6. kān, inkān or ilkān introducing alternatives

kān may introduce alternatives, like in hakamuw 'alēhuw b sinih țarid ... min Sìnih b ilmarrrah ḥatta mā ywakklüne ... kān wālidtī w uxtī w uxūyw ...yainiy nāsī..." they sentenced them to a year of total exile ... from Sinai, so that they would not (be able to) feed us, be it my mother and my sister and my brother and... (all) my family, that is".

Another example is: $w$ inḥutțuh fiha. kān giliệ aw irfayyi lāzm iykūn miš ya'niy nō'ayn "and we put it in there. Be it thick or thin, it shouldn't be two kinds (mixed), that is".

4.7.3.2. Absence of a conditional particle

Often conditional sentences are not introduced by a particle, e.g. il...alhìn ákalat ib sínnaha, hū ytiff kidiy f-ìdu, iw yaxabața kidiy "the... now if it has bitten with its tooth, he (i.e. the snake charmer) spits in his hand, like this, and slaps it (sg. fem. i.e. the place of the bite)" and ligațāh fi lxēt. iw mnä ... mnimšiy šwayyah zayy 'ašarah mitir, iw binunšur țāniy "if we have 
caught it in the net, (and) then we what? We walk a little farther, like ten metres, and we throw out (our net) again"..$^{8}$

\subsection{Presentative Particles}

4.8.1. ir ${ }^{\mathrm{c}}$ or ar $^{\mathrm{c}}$

Presentatives ir' or $a r^{\prime}$ were not recorded.

4.8.2. hē + suffix

To draw the listener's attention to something or someone, a presentative particle $h \bar{e}$ may be used followed by a personal pronominal, e.g. hēhù ği' "there he is!", hēhī ğàt "there she is!", hēhuwwa ǧuw "there they (masc.) are!", hēhinnah ğin "there they (fem.) are!" (lit. "has/have come").

\subsubsection{Particle wlin $\sim$ wilin, win}

The particle wlin is used mainly to present a sudden or unexpected turn in a narration, ${ }^{99}$ but in the following example the development referred to is hardly unexpected or sudden: 'ašar dagāyig iw tiglibha ma fiš dig ... kam digìgih $w$ tiglibha 'a lğâl ițtāniy $w$ linnhī yōm ástuwat ... bitțalliḥha "ten minutes and you flip it over after less than a min ... a few minutes and you turn it on its other side and there it is, when it has become cooked...you take it out".

Another example is with the variant particle ilin + suffix: $w$ fi lxarrāfah diyyih ... ilinnih irkāb ğin ${ }^{100}$ "and in this story ... there they were, the riding animals came" (recorded in MzA).

\subsubsection{Particle wlā +}

An example of the presentative particle $w l \bar{a}$ (used more or less like $w l i n$ ): w ibtalhagha 'a ș̣āăg galibtēn talātih wlāha mistawyih "and you put it on the șāğ and flip it two or three times, and there it is: cooked!" (recorded in BWA).

${ }_{98}^{8}$ The fishing technique described is with nets (sg. šuggah, pl. šgāg) on a line (xayt; here $x \bar{e} t$ ) while the fishermen stand on the edge of the coral reef by the deep water ('ala harf ilbăhah) and throw out their nets on the deep side.

99 See Blanc 1970:34 (145).

${ }^{100} r k a \bar{b} b$ is pl. (of small numbers) of irkābih. Notice that the reference is in the pl. fem., see 'concord' in 4.16. 


\section{9. ġayr}

$\dot{g} \bar{a} r(<\dot{g} a y r)$ may be used preceding imperfect forms to express the necessity of the action, e.g. ilimhilliy gär iyxaddim 'a dd d̦ayf "the host should serve the guest" and rawwahna luh, ana gult èh? ġär arawwih luh. awaddìh lalhurmah diy, yimkin áššifi' 'al-îdhi "we went to him, [and] I said what? I need to go to him. I'll take him to this woman, maybe she can cure him (lit. the cure is by her hand)".

\subsection{Intensifying Particle la}

The particle la intensifying the 1st p. sg. com. was not recorded.

\subsection{1. bidd or widd + pron. suffix}

To express "want" or "need" speakers of BWA use bidd and widd side by side (the latter is heard more inland, the former nearer to the coast). In MzA only suffixed bidd is common. ${ }^{101}$ Examples for "need" or "want" are: widdna nlaggiy Wãdiy Sli"102 "we want to go to Wadiy Islah" (BWA), ēš bidduk? "what do you want?", bidduh yāxid šiǧár mi-nhāniy iyhálliluh "he wants to take plants from here to analyze them (sg. masc.)".

Like in other dialects as well, often not only volition is expressed, but also a sense of futurity of the action expressed in the following verb, e.g. halhinit bidd-āxd iššuggah w uxušš...w unšur "now I shall take the net and go in (i.e. into the water), and spread (it) out".

\subsection{2. ‘̄a}

The particle ' $\bar{a} d$ is current to express "so, thus, then". Examples are: ' $\bar{a} d$ yōm tišrif 'ala šarafat ilGā ibyinșabb ġād fi sēl Wādiy Fērāan "so when you look out at the highest point of alGā' it flows there into the flood course of Wadi Fērānn" and 'âd wèn lagga? "so where did he go?".

\subsection{3. yabga}

yabga is not very current, but may be heard at times meaning "so, then", as in yabga țámhin hiluw "so their (pl. fem.) taste is sweet".

\footnotetext{
${ }^{101}$ In group I widd is current.

${ }^{102}$ Wãdiy Isla (as it is usually indicated on maps) runs from almost due east of ațūur into the mountains. In group I the name of this wadi is pronounced Sliy (cf. 1.2.4.4. and 3.1.5.).
} 


\subsection{Characteristics of the Narrative Style}

\subsubsection{Imperative of narration}

The narrative imperative is one of the characteristics of the narrative style. An example is $w$ ashabuw syūf. zimān ġār b isyūf. [...] iw taxx taxx taxx $w$ asla'uw kitif wāḥid, iw hū yušurud, úšurduw rawwḥuw tTarāāin..."and they drew (their) swords. In the old days it was only with swords [...] And they hit and hit and hit, and they wounded somebody's shoulder, while he was fleeing, they fled and went to the Tarābīn". Another example is (after somebody had stepped on a mine) innās ğuw 'ilēh dammuh kulluh $f i$ ddag'ah, nāzil ... zayy ssēl. limmūh $w$ ahānuw dammuh, iw hutțuw 'a lbi īr iw yimšuw "people came to him, all his blood had run on the ground ... like a flood. They gathered it together and buried his blood and put him on a camel and they went away".

\subsection{2. kān as a temporal marker}

As another characteristic of the narrative style, unconjugated kān can be used as a marker to indicate the past, e.g. bass zimān fi sSu'üdiyyah hnütiy kān innās mā btalga tākil "but in the past in Saudi Arabia over there people could not find (anything) to eat", ilmayyah kān bitganniy fi lwādiy hād "water used to flow through (narrow) canals in this wadi". In most cases, however, kān is conjugated for number and gender.

\subsubsection{Dativus ethicus}

Several instances of the ethical dative were recorded. Examples are: kān 'indin-ayw-marākib ... marāāib bass iṣgayyrāt yainiy ... iṣggayyrāt ...tálātah mitir aw arbá ah mitir ya'niy timšiy bēhin min ba'ad ášša'ab timš luk itnēn bēha "yes, we used to have boats... boats, but small, that is...small ones ...three or four meters (in length), that is, you go with them beyond the reef, you go for yourself two (kilometers) with them". Another exam-

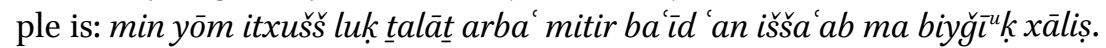
lākin law mišèt 'á-šša'ab byimšiy warăa ḳ "when you go (for yourself) in (into the sea) three or four metres, far away from the reef, it (i.e. the Morray eel) will not come to you at all. But if you walk on the (edge of the) reef, it will come after you". 


\subsection{Pluralis paucitatis}

For limited or countable numbers often the healthy plural form is used, instead of the broken plural. Examples are: tamān fațīrāt 'ašar fațīrāt "eight loaves, ten loaves". Another pl. form, used for greater or unspecified numbers is the broken pl. fațayir.

Similarly, a pl. is used in designations of quantity like w ithuțt 'alēhin $\bar{e} h$ ? gadd 'ašar iğrâmāt minhin "and you put what on them? About (the quantity of) ten grams of these (lit. them (pl. fem.)" (see remark in fn 63, p. 148) and 'ašar kīlāt ( 'ašarah kìlu) "ten kilos".

\subsection{Concord}

Limited or countable numbers of things are referred to in the pl. fem. and so are plurals of animals. Examples are: binğìb arruğfận iw birrağğidhin fásșahan "we bring the loaves of bread and we pile them up on a plate" and il'ašar t-aläf dillih talghin 'išrin alf"these ten thousand (pounds), you'll find them (to have increased to) twenty thousand". Other examples are: halhịn ilwidyān ... ag̣labìtttin la Biniy Wāssil ... ka milkiyyih, tawğad lēhin warág $f i$ ddēr, tawğad lēhin warág kidiy ...ya niy...a ag̣labìyt ilwidyān inNabig...iššarim ... "nowadays most of the wadis belong to the Baniy Wāṣil ... as property, you'll find a piece of paper on them in the monastery, you'll find a piece of paper on them like that... that is ... most of the wadis near Nabg, Šarm...". Also plurals of animals are referred to in pl.

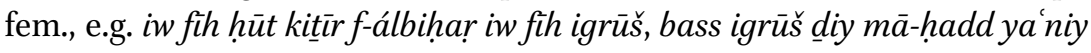
mä-hadd ibyākilhin.bass ya niy ibniștādhin barduh b ilxayt biyğin fi lxayt barduh "and there is a lot of fish in the sea, and there are sharks, but these sharks, that is, nobody eats them. But, that is, we fish for them also with a line, they also come on a line".

\section{A Sketchy Remark on Pitch}

The type of pitch often heard in the speech of (predominantly older) men of group I was not heard in MzA or BWA. ${ }^{103}$

${ }^{103}$ I merely conclude the absence of this feature in my material. I do not exclude the possibility of its existence in this group. 